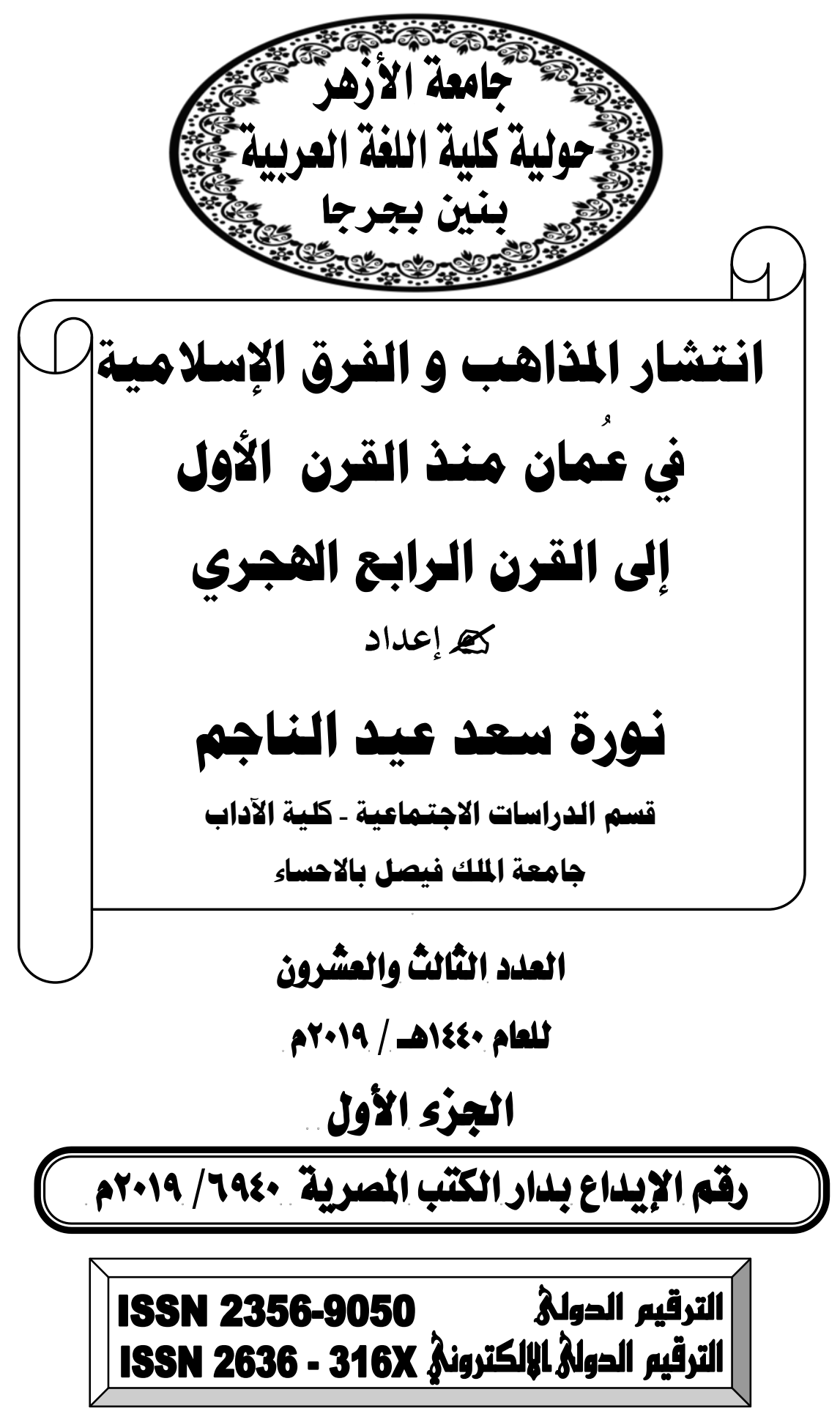




\section{هلغص الدراسة}

انتشار المذاهب و الفرق الإسلاهية في عُمان هنذ القرون الأول

\section{إلى القرن الرابع الهمري}

عرفت عُمان كغيرها من مدن شبة الجزيرة العربية العديد من الديانات

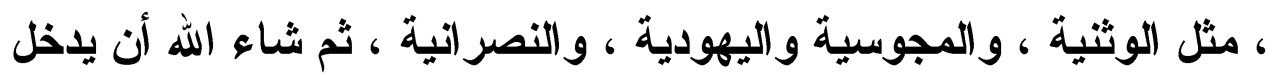

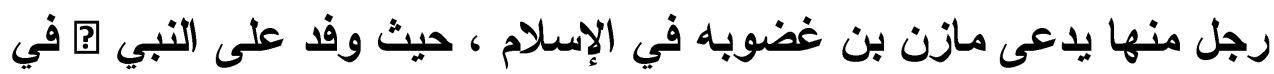

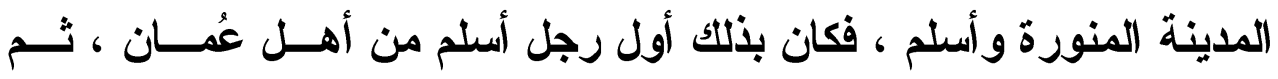

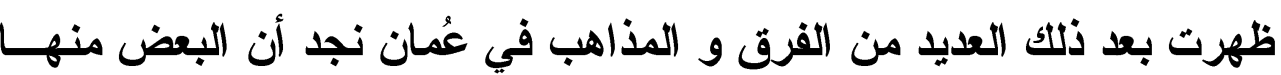

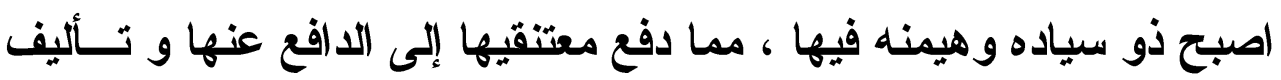

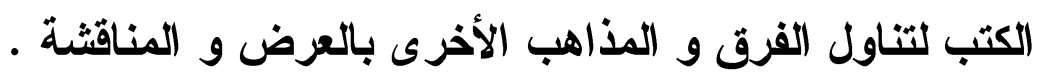

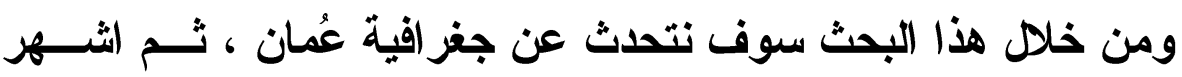

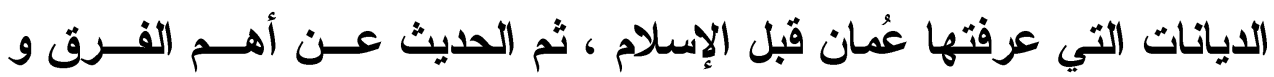
المذاهب الإسلامي في عُمان خلان فتره الار فاسة. كمّ إعداد

نورة سمد عيد الناجم

قسم الار اسات الاجتماعية - كلية الآداب

جامعة الملك فيصل بالاحساء

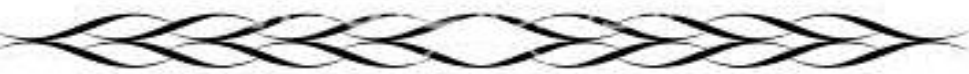


الترقير الدوله

ISSN 2356-9050

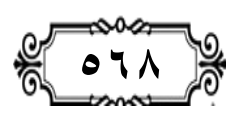

حولية كلية اللفة العربية بجرجا موكية مجلة علمية محكمة الفربة

\section{Study Summary}

The spread of Islamic schools and sects

in Oman since the first century

To the fourth century AH

Oman, like other Arab Peninsula cities, has known many religions, such as paganism, mysticism, Judaism, and Christianity. Then, God willing, a man named Mazen Bin Gharoubah entered Islam. He was the Prophet of Medina in Islam. The people of Oman, and then emerged after many of the sects and sects in Oman, we find that some of them became sovereign and dominated by, which led the followers to the motivation and the writing of books to address the difference and other doctrines in the presentation and discussion.

Through this research we will talk about the geography of Oman, then the most famous religions known by Oman before Islam, and then talk about the most important Islamic sects and sects in Amman during the study period.

\section{Setup}

\section{Noura Saad Eid Induced}

Department of Social Studies - Faculty of Arts

King Faisal University 


\section{الاقدِّمِّة}

كانت عُمان كغيرها من مدن شبة الجزيرة العربية وجدت فيها العديا مــن الايانات قبل الإسلامي ومن اشهر تلك الايانات الوثنية ، والمجوسية واليهودية ، والنصر انية ، ثم شاء الله ان يهاى الله رجل من أهل عُمان من بلاه سمائل اسمه مازن بن غضوبه ، حيث سمع بخبر دعوه التبي صلح الله عليه و ســلم ، فثـــ راحلته إلحى المدينة المنور فكان أول من أسلم من أهل عُمان ثم تتابع قدوم الوفود إلى المدينة المنورة للاتقاء بالتبي صلى الله عليه وسلم ونيل شـرف صسـبته؛ هيث كاتث وفادتهم أثناء حياته، كما تشرف البعض الآخر بصحبة صحابته؛ حيث كاتث وفادتهم بعد وفاته - صلى الله عليه وسلم- وعددهم ستة عشر وفدًا ، ثــم

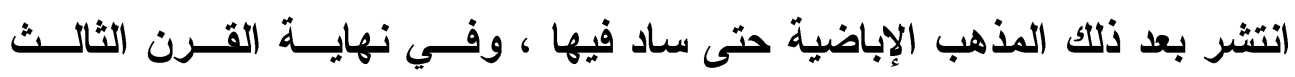
الهمجري/القرن التاسع الميلادي ظهرث العديا من الأفَار الاخيلة في عُمان ؛ مثل فكر القر امطة والقدرية والمرجئة، فكاتت صحار موئلاً ومستقرَّا للأفكار القادمـــة

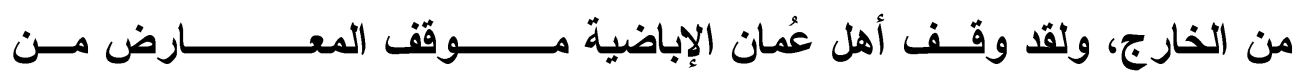

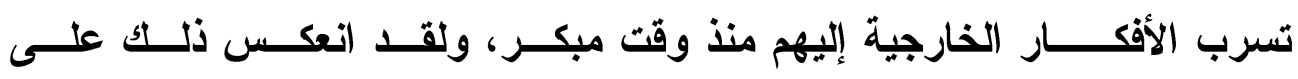
المصنفات العُمانية التي تناولث تثلك الأفكار بالعرض والمناقشة؛ حـــث ناقثــــا

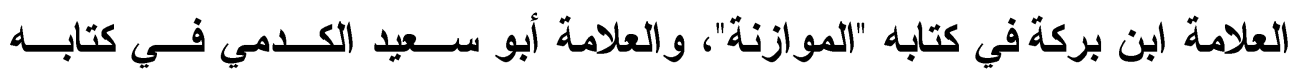
"المعتبر" •ومع انتشار المذهب الاباضي الا ان المذهب السنى ظل منشر فيها بل نه زاد انتشاره فيها في نهايـة القرن الثالث والتصف الأول مــن القــن الرابــع الهجري/نهايه القرن التاسع الميلادي والنصف الأول من القرن العاشر الميلادي، وذلك بسبب تبعيتها للخلافة العباسية، فقد تولى السلطة فيها ولاة من قبل الخلافة، أولهم أحمد بن هلال ، ثم أسرة آل وجيه التي كانت السلطة فيها وراثبـة حتى منتصف العقد السادس من القرن الرابع الهجري/منتصف القرن العاشر الميلادي. وفي هذا البحث سوف نسعى إلى اعطاء نبذه عن جغرافيه عمان ، ثم ثنقل بعـد 


\section{الترقيم الدوله \\ ISSN 2356-9050}

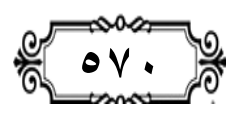

ذلك إلى الحديث عن أهم الايانات المنشره فيها قبل الإسلام ، ثم تتنقل بعـد ذلــــ لتناول الحديث عن أهم المذاهب و الفرق التي عرفتها عمان خلال فتره البحــث ، و ختمت الدراسة بخلاصه بينت فيها أهم نتائج البحث التي توصلت إليها .

\section{جغرافية عُمان}

\section{هـوقع عُمان:}

تقع عُمان في الجنوب الثرقي من شبة الجزيرة العربية و إلى الثرق من هجر، فيحدا من الشمال بلاد البحرين، ومن الثرق الخليج العربي وخليج عُمان، ومن الجنوب يحدها بحر العرب ومن الغرب يحدها حضرموت وصــراء الربــع

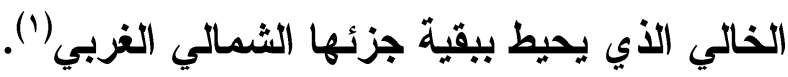
وهذا يتضح لنا الموقع الاستر اتيجي الأي تتمتع به عُمان، ومما لا شك فيه أن هذه الخلجان والبحار أدت دورًا بارزًا في ازدهار التجارة في عُمان.

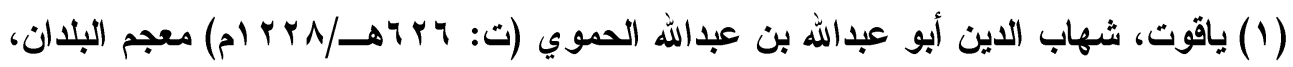

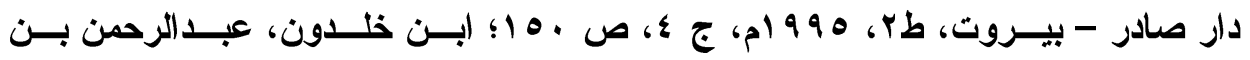

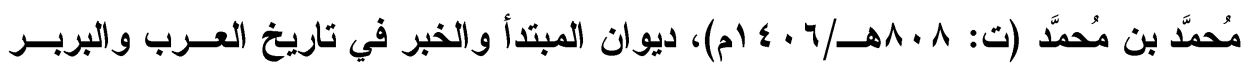

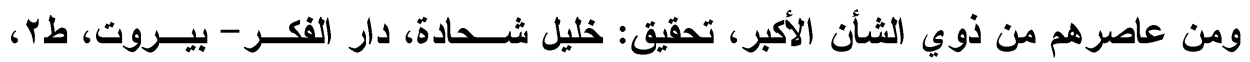

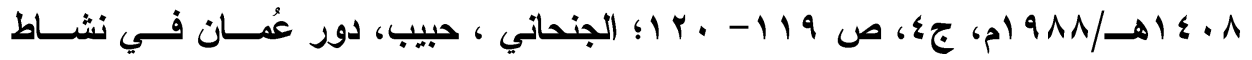

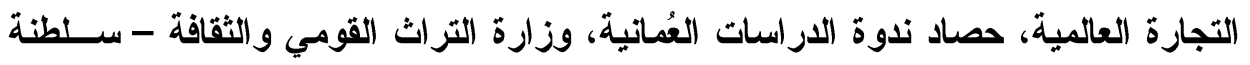

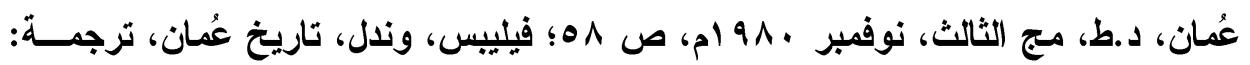

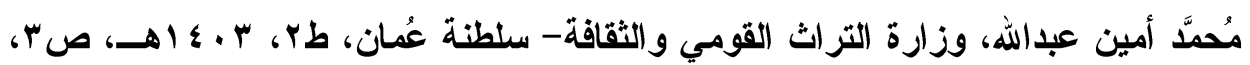

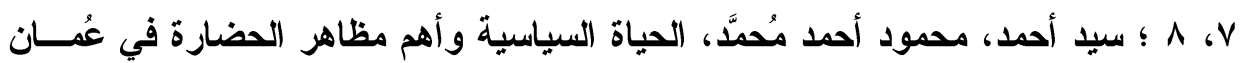
في الفترة من القرن الرابع حتى القرن السابع الهجري، جامعـة الزقــازيق، كليـة الآداب،

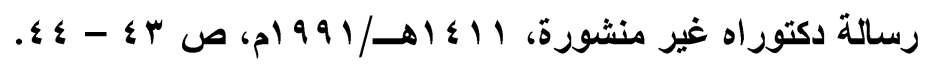

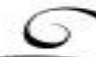




\section{السطح والإناخ:}

تتميز عُمان بتنوع التضاريس فيها؛ فهي تتكون من سلاسل جبلية، وهضاب

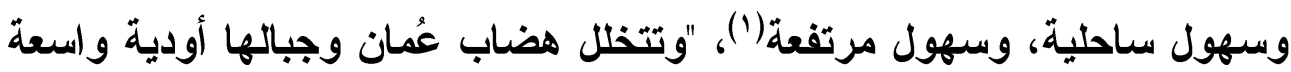
وكثيرة، تمتد خلقها من الناحية الغربية مناطق صحر اوية مترامية الأطراف، تمتد باتجاه الغرب حتى تتصل بصحراء الربع الخالي"(؟)، ونظر التباين التضاريس فيها فقد اختلف المناخ من منطقة إلى أخرى، فهو حار رطب في المناطق الســاحلية،

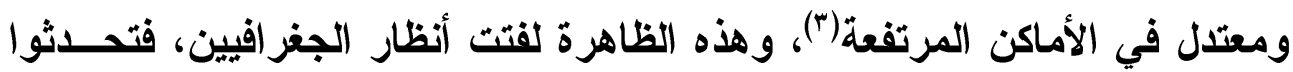
عنها كظاهرة جغرافية متميزة، ومن ذلك ما ذكره ابن الفقيه أن الحجاج سأل ابن

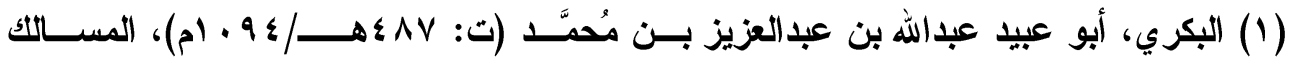

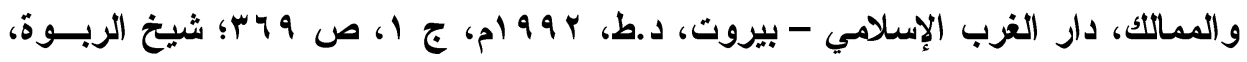

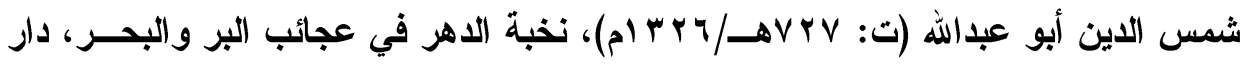

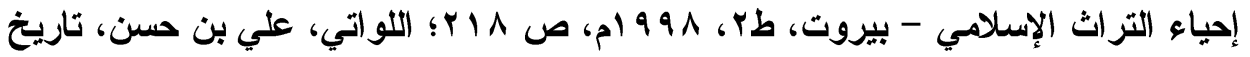
عُمان الحضاري من القرن الرابع حتى القرن السادس للهجرة دراسة في العي الحياة الاجتماعية

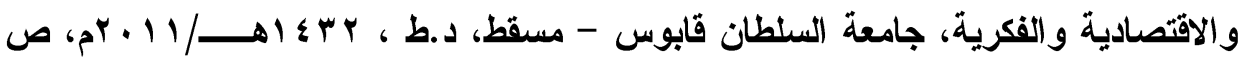

$$
\text { ro }-r \varepsilon
$$

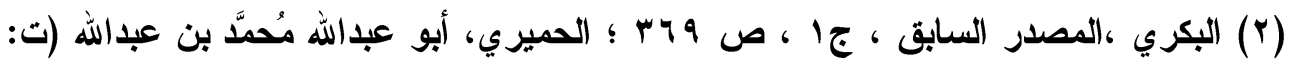

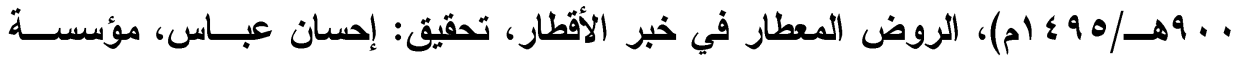

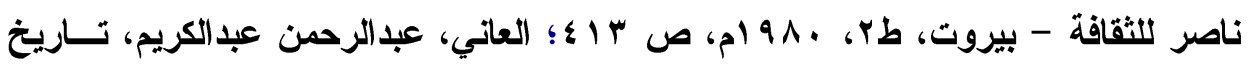

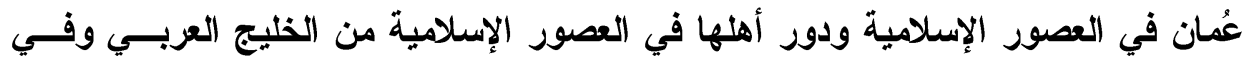

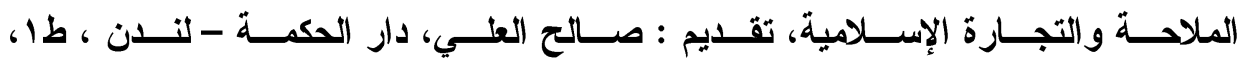

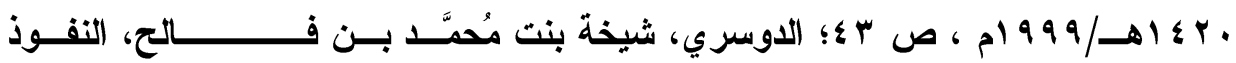

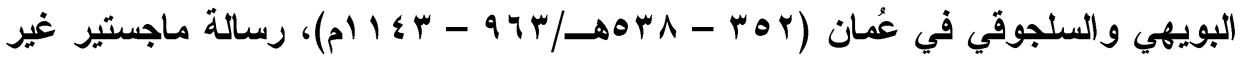

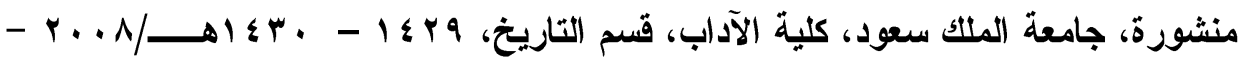

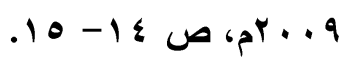

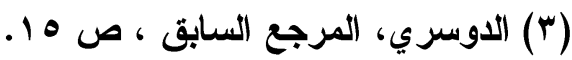




\section{الترقير الدولخ}

ISSN 2356-9050

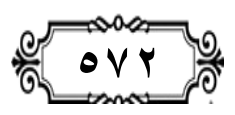

القرية(')عن عدد من الأقاليم ومنها عُمان فقال: "حرها شديد وصيدها عتيــد"(؟)، ومن شدة حرها أصبح يضرب بها المثل فيقال "ولا مصيف كمصيف عُمان"("). وتذكر بعض المصادر: "وعُمان بلاد حارّة جروميّة وبلغني أنّ بمكان منهــا

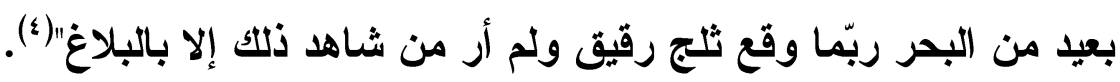
ونستتج مما سبق أن مناخ عُمان يختلف من منطقة إلى أخرى وذلك بسبب تباين التضاريس، ففي المناطق الساحلية نجد المناخ حارًَا رطبًا في الصيف، أمسـ

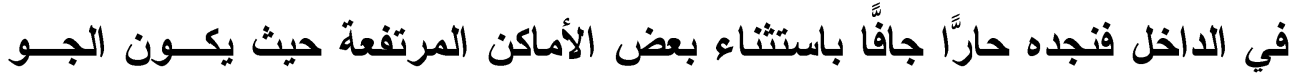

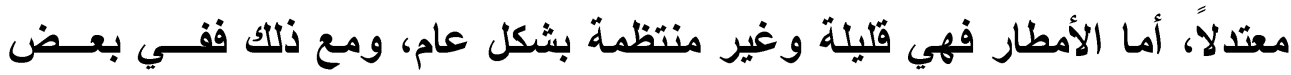
الأحيان تهطل أمطار غزيرة)(ه).

(1) ابن القرية: هو أيوب بن زيد بن قيس بن زرارة الهلالم خطيب يضرب به المثل، حتى قيل

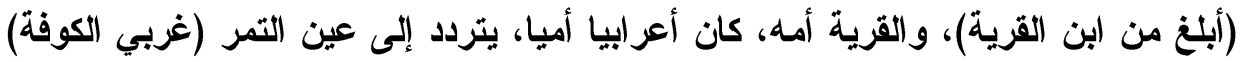

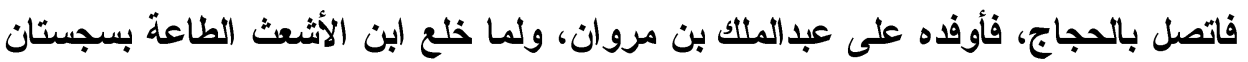

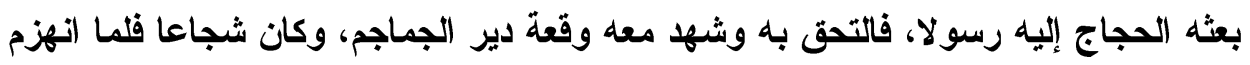

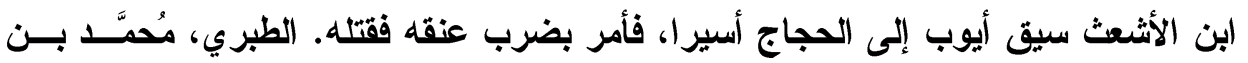

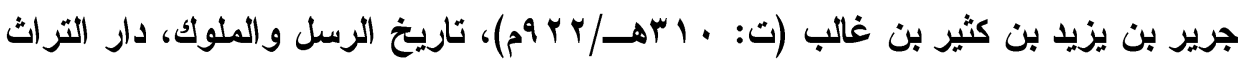

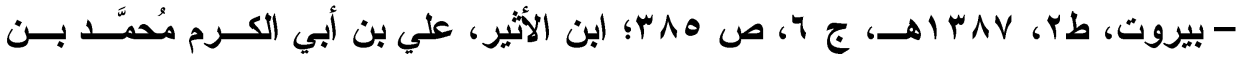

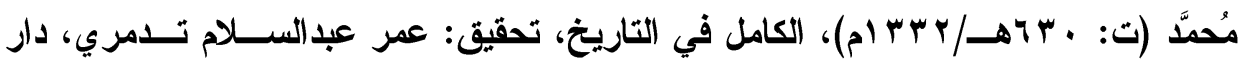

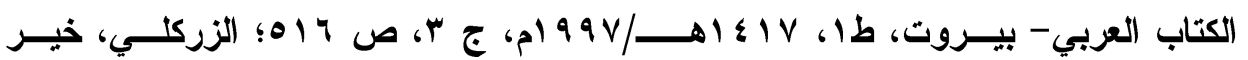

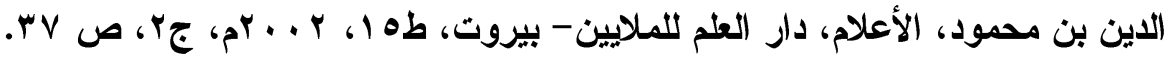

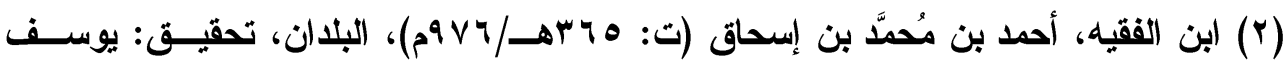

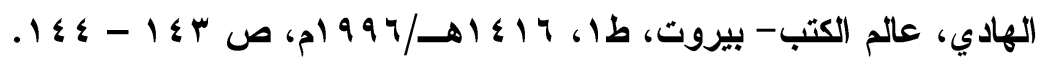

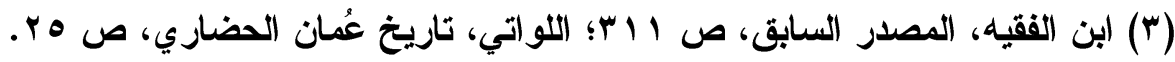

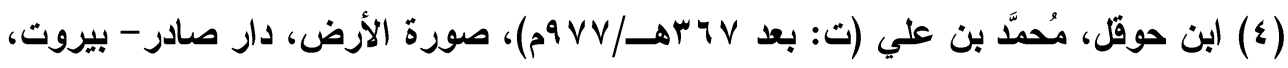

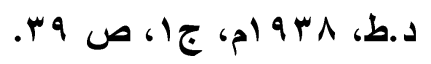

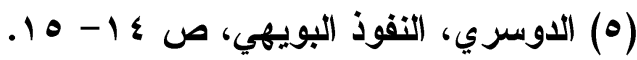




\section{أصل تسمية عُمان بهذا الاسم:}

تباينت الأراء في سبب تسمية عُمان بهذا الاسم، فالبعض رأى أنها ســميت

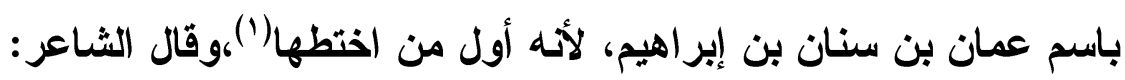

أين عَمَّانُ من قُصورِ عُمانِ (r)

والبعض يرى أنها سميت عمان باسم عمان بن إبراهيم الخليل، وقيل أيضًا

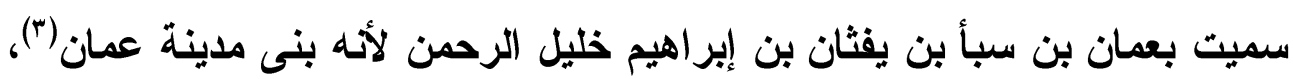

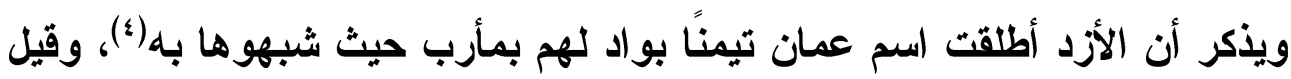

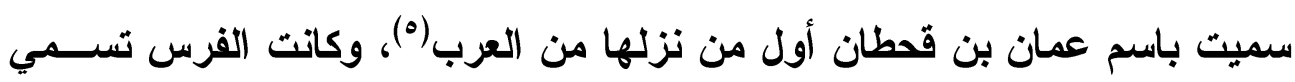

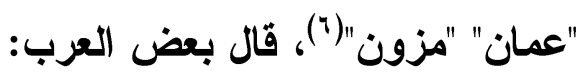

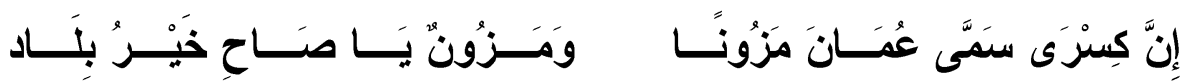

(1) الحميري، الروض المعطار ، ص ب إ؛.

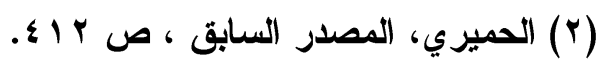

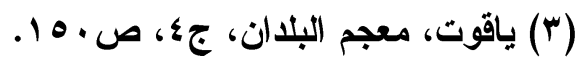

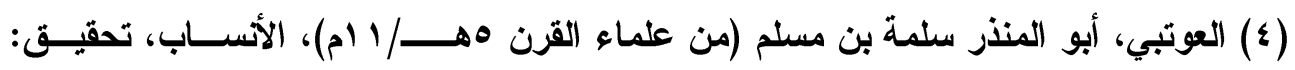

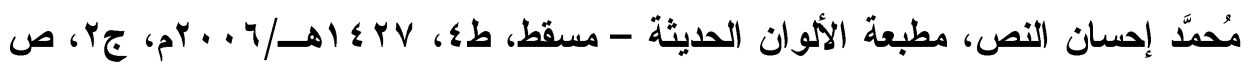

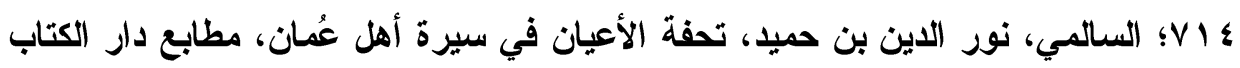

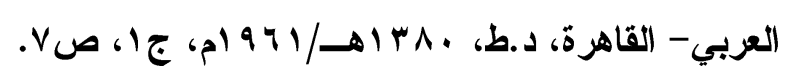

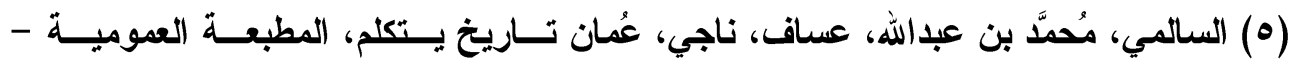

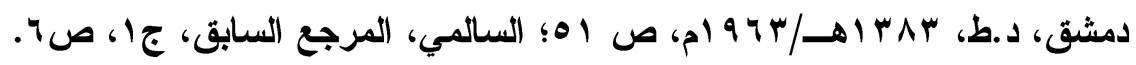

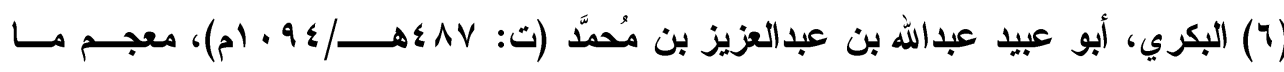

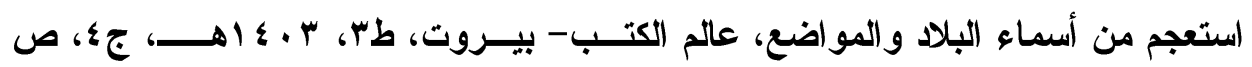

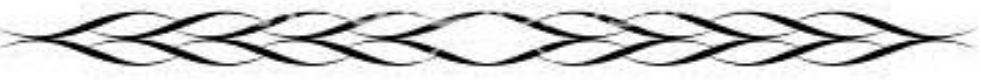




\section{الترقير الدولخ}

ISSN 2356-9050

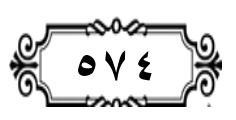

حولية كلية اللفة العربية بجرجا مجلة علمية محكمة

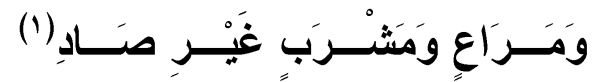

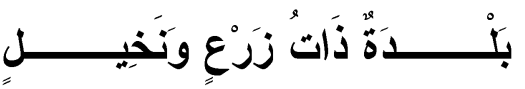
وبعض المصادر ترى أن عُمان سميت بهـــا الأســـ لأتهــــا بــلاد غنــــة

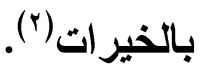

\section{المياة الدينية في عُمان قبل انتشار الإسلام}

لقد كاتت عُمان كغيرها من بلاد الجزيرة العربية تنتشر فيها العديا من الايانات، ومن أشهر تثلك الايانات:

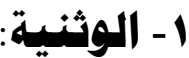

لقد كان العرب على دين إبراهيم -عليه السلام- دين الحنيفية، إلا أنهم مع مرور الزمن انحرفوا عن جادة الطريق السوي، فاعتثقوا الوثنية التي انتشرت في الجزيرة العريية(ّ)، ومنها عُمان فأصبحت هذه الايانة هي الغالبة على أهلها في الجاهلية، فكان لقبيلة "طيئ" التي كانت تسكن "سمائل" من عُمان صنم تعبده

(1) الإزكوي، سرحان بن سعيد (من علماء القرن ب اهـ/1 ام)، كثف الغمة الجامع لأخبـار

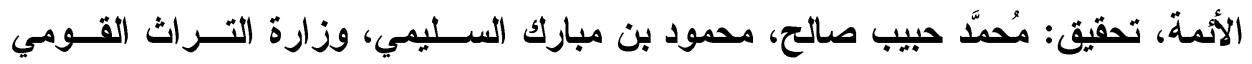

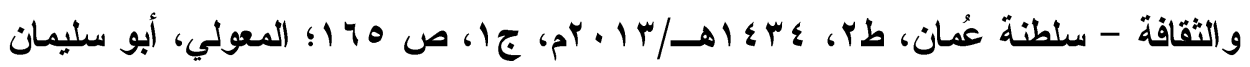

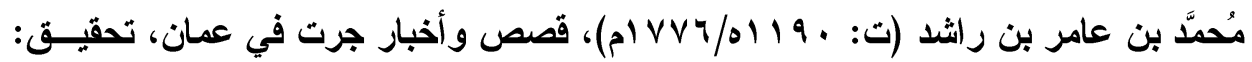

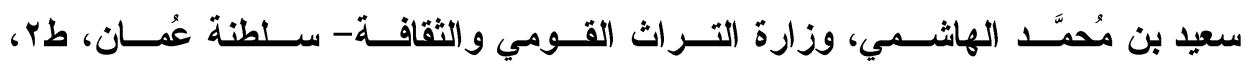

$$
\text { (r) }
$$

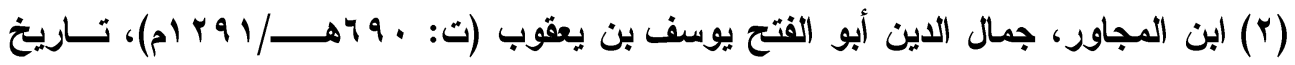

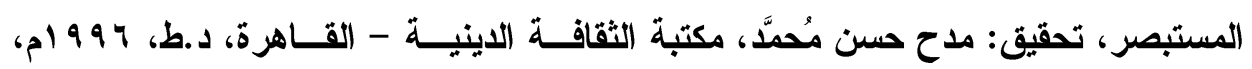

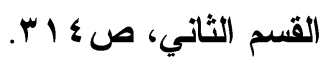

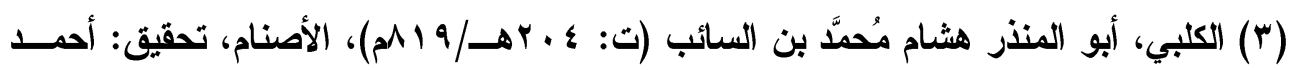

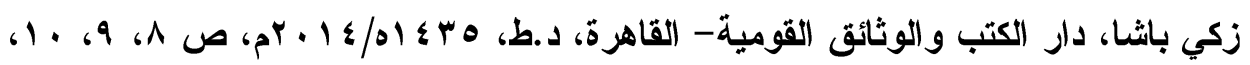

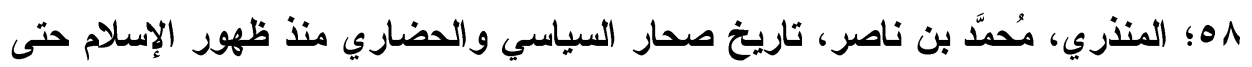

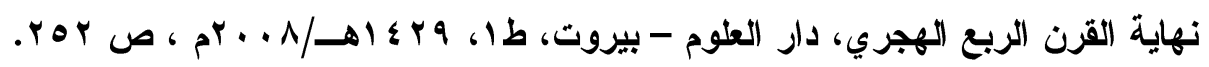

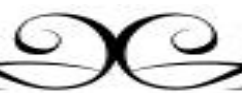




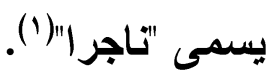

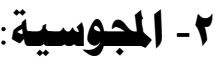

عرفت عُمان الايانة المجوسية، كنتيجة طبيعية لاستيطان الفرس فيها، ويبدو أن عرب عُمان لم يعتنقوا هذه الايانة، وأنها كانت محصورة في الفرس فقط، ولقد عمل العُمانيون بعد ظهور الإسلام على طردهم بعد رفضهم الدخول في

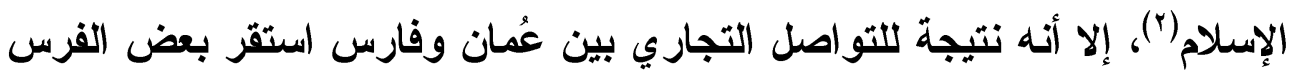
في صحار فكان منهم رجل مجوسي يقال له "أبو (الفرج(")" يعد من أغنياء المدينة وله خانات تجارية(؛)، ولقد أرسل النبي صلى الله عليه وسلم عمرو بن العاص(ه)؛

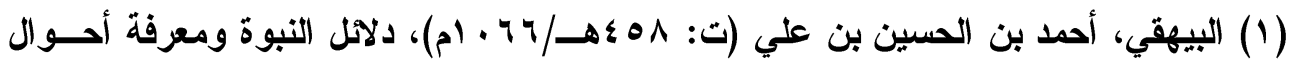

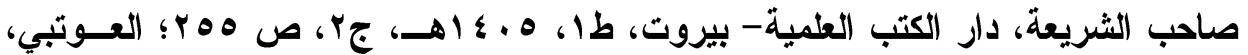

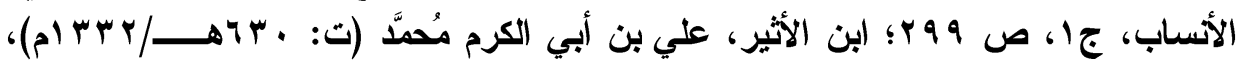

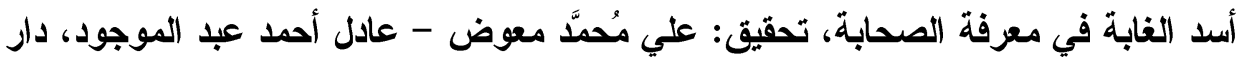

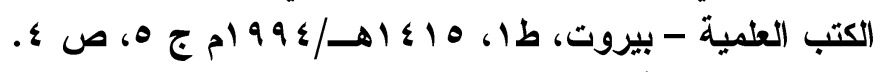

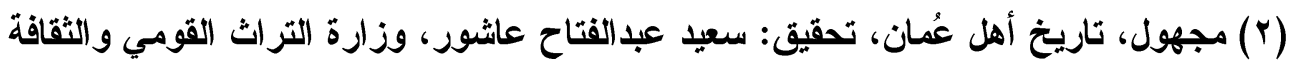

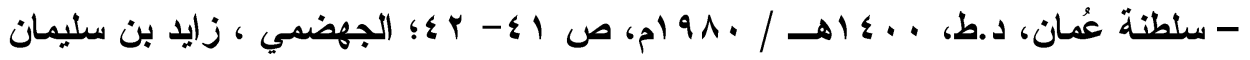

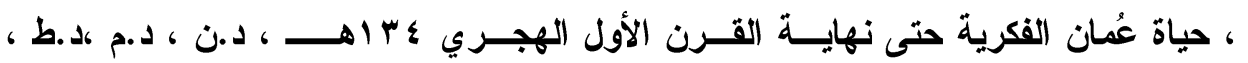

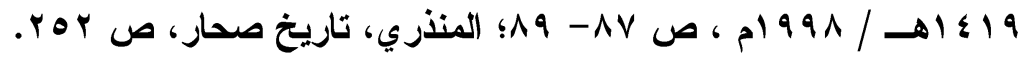

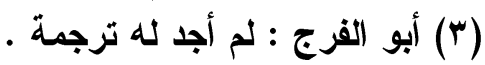

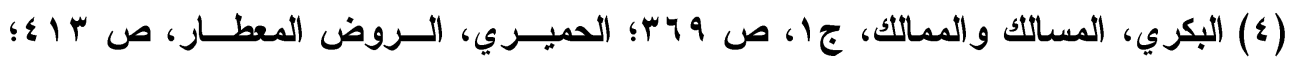

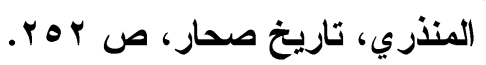

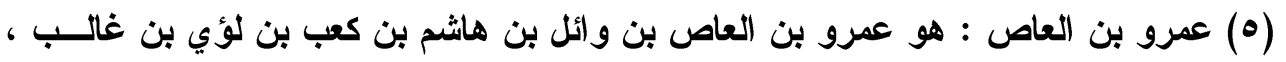

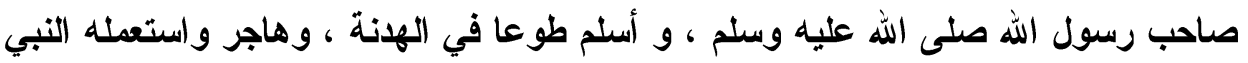

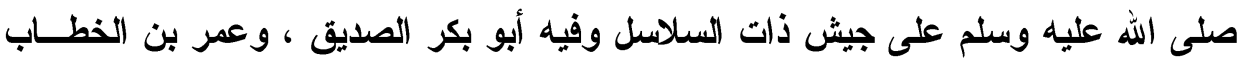

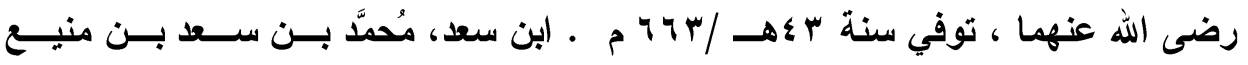

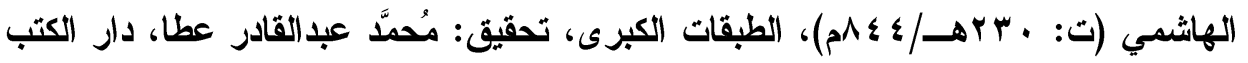

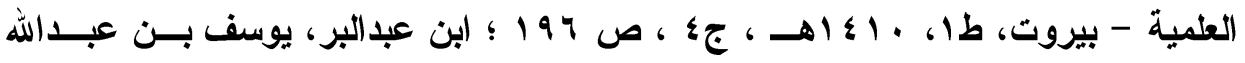

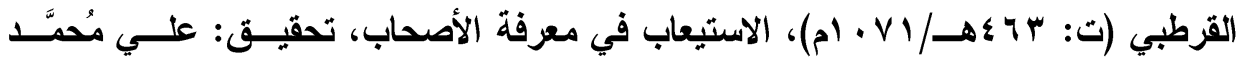

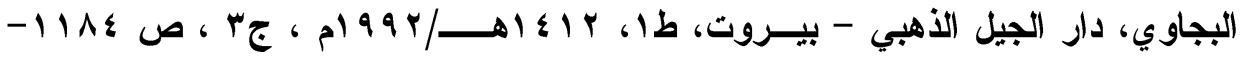

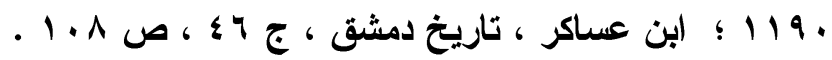




\section{الترقيم الدوله \\ ISSN 2356-9050}

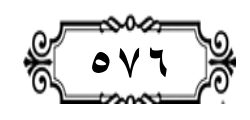

حولية كلية اللفة العربية بجرجا

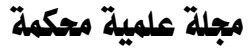

وأبا زيد الأنصاري(') إلى عُمان على أن يأخذا الصدقة من المسلمين، والجزية من

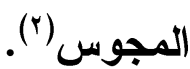

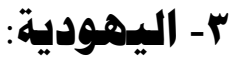

لقد انتشرت الدياتة اليهودية بعُمان، فعندما توفي النبي صلى الله عليه

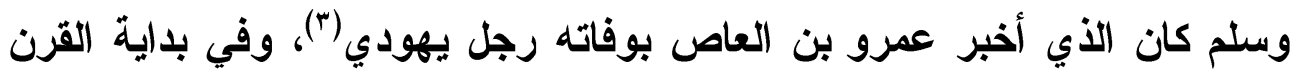

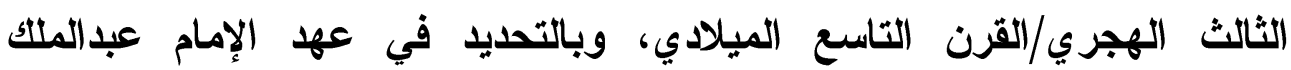

(1) أبو زيد الأنصاري: اختلف في اسمه؛ قيل: قيس بن سكن بن زيد، وقيل: عَمْرو بن أخطب، وهو أحد الذين جمعا القرآن في عهر النبي صلى الله عليه وسلم ولقد بعثه النبي صلى الله

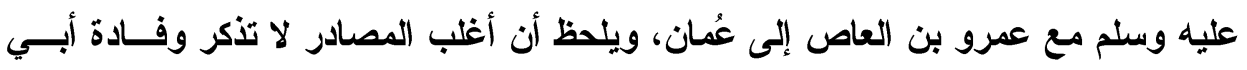

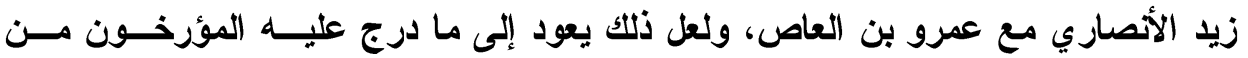

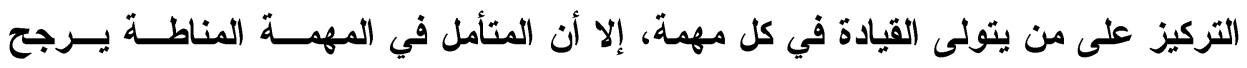

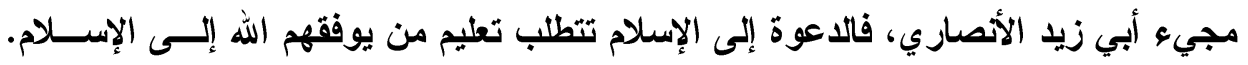

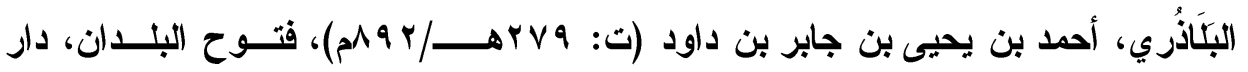

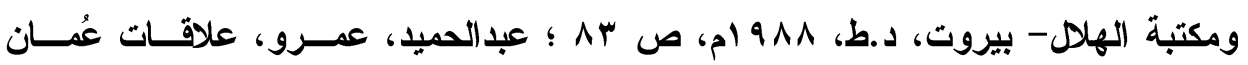

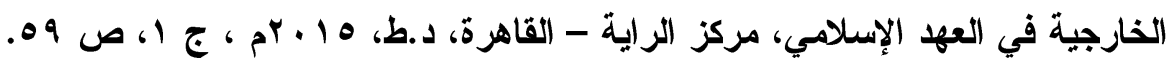

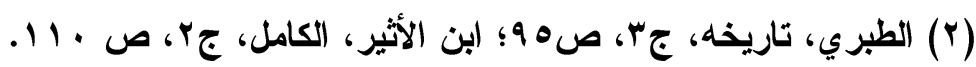

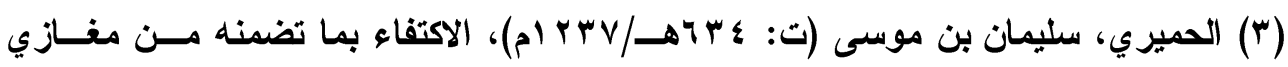

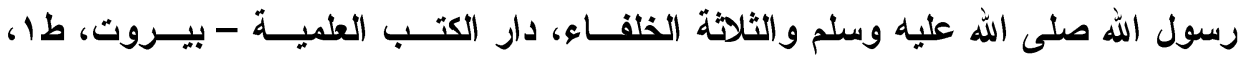

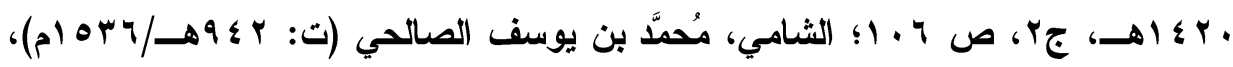
سبل الهاى والرشاد في سيرة خير العباد، وذكر فضائله وأعلام نبوته و أفعاله وأحواله فئه فئسي

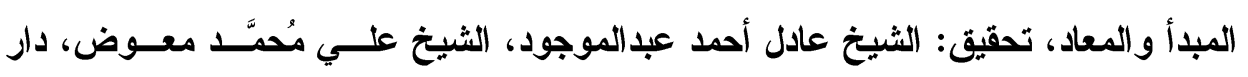

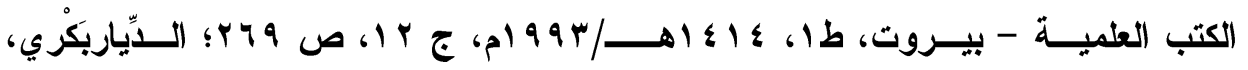

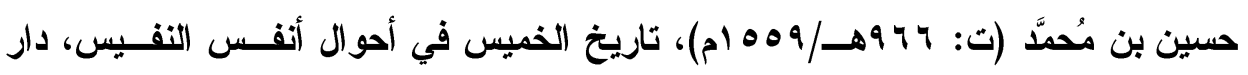

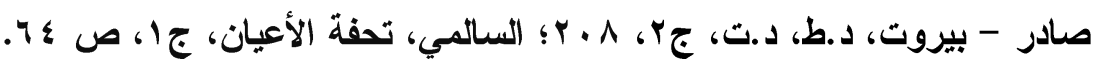


بن حميل(') وصل إليه كتاب من والي صحار يذكر فيه أن يهوديين اقتتلا بالسلاح فقال أحدهما: "أثهر ألا إله إلا الله وأثهر أن محمدًا رسول الله، أعينوا أخاكم

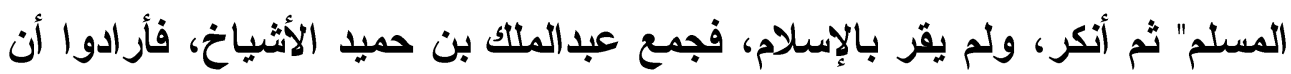
يجيبوا فيه جوابا، كأنهم يرون ذلك يلزمه، ثم كتبوا إلى موسى بن علي (r) برحمه الله، فكتب أن يشد على اليهودي ويُهدد بالقتل، فإن أسلم قبل منه وإلا فلا قتل يتل عليه، وقال أبو عبدالله(ّ) إنما لم يلزمه القتل لأنه لم يقر بجملة الإسدلام، لأن القول الأي يلزمه فيه الإسلام، ويجب عليه القتل في تركه إذا قال: "أثهه ألا إله إلا الله، وأشهد أن محمدًا رسول الله، وأن جميع ماجاء به حق من عند الله" قال:

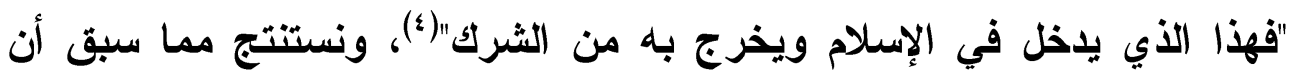
الايانة اليهودية كانت موجودة، ولكنها لم تكن منتشرة كالنصر انية.

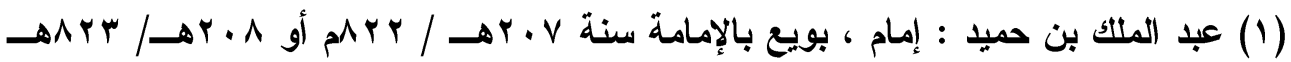

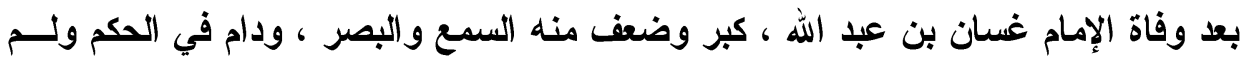

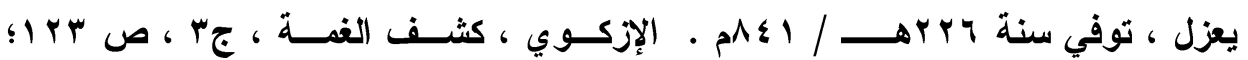

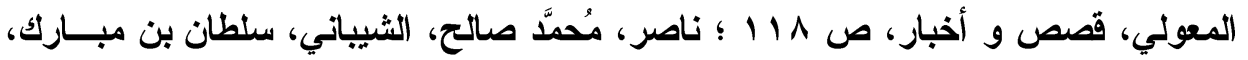

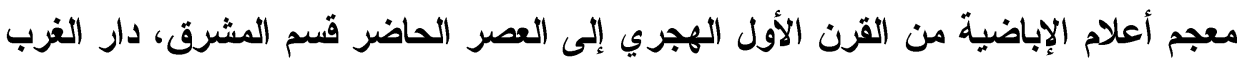

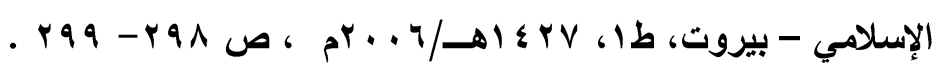

(r) موسى بن علي : هو موسى ين علي بن عزرة البكري الإزكوي ، يكنى بأبي علي ، قاضي الإسي

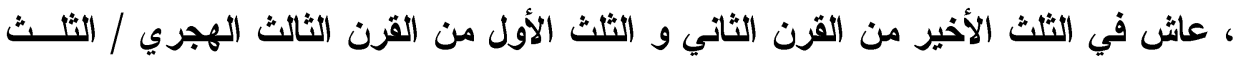

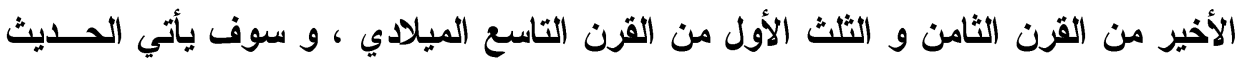

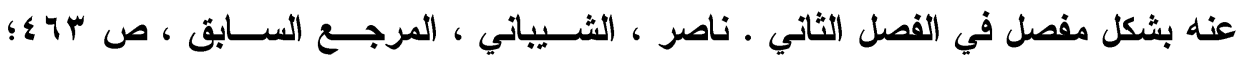

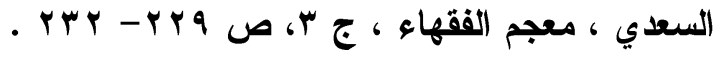

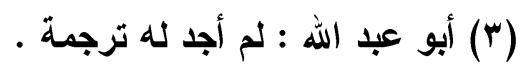

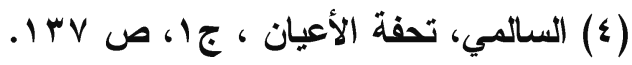




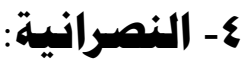

عرفت عُمان هذه الدياتة، وقد كان كعب بن برشة الطاحي(') نصرانيا قبل

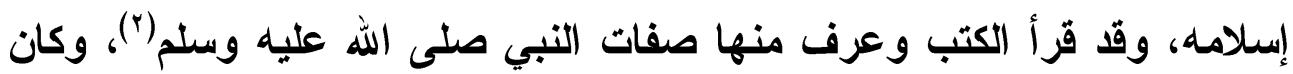

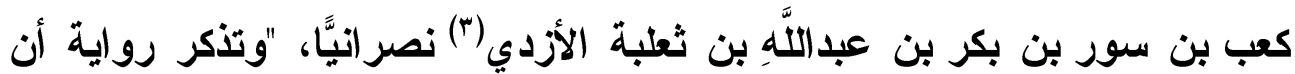

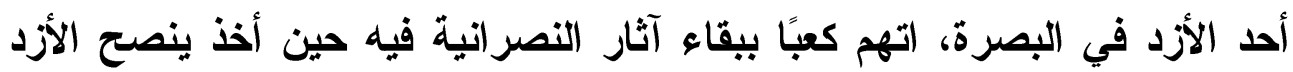
باعتزال القتال قبل يوم الجمل، وقبل أن ينضم إلى عائشة رضي الله عنها"(أ).

\section{المذاهب والفرق الإسلاهية}

لقد أثرنا آنفا إلى أن أهل عُمان كانوا يعبدون الأصنام، ومن أثشهر هذه الأصنام "تاجر" أو "باجر"، ولقد كانت كثير من القبائل تعظمه، وكاتت بلاة سمائل

(1) كعب بن برشة الطاحي: ينتمى إلى قبيلة طاحية، كان نصر انيا، قرأ الكتب، قدم إلى المدينة

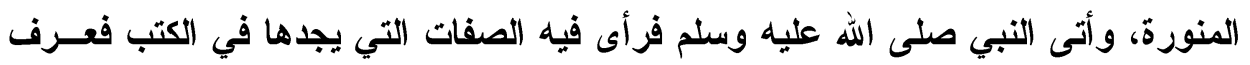
أنه نبي مرسل، فعرض عليه النبي صلى الله عليه وسلم الإسلام فأسلم. العوتبي، الأسلاب،

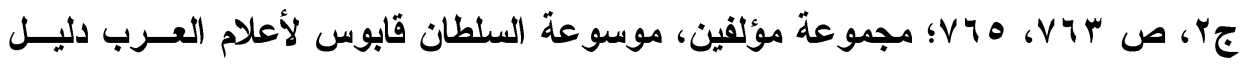

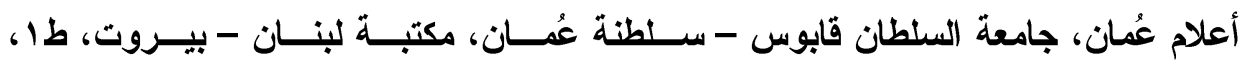

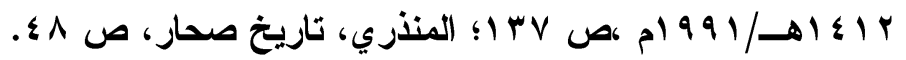

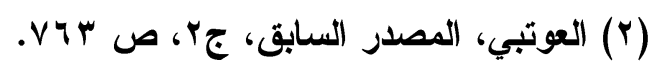

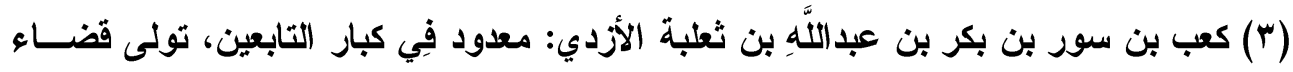

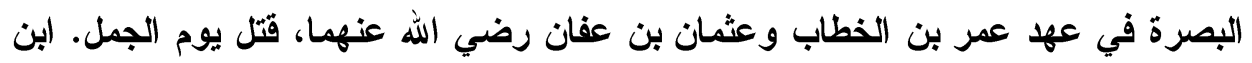

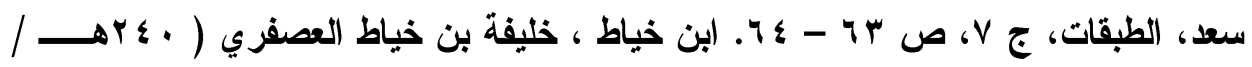

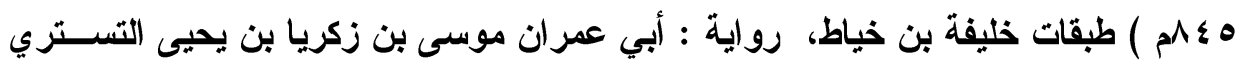

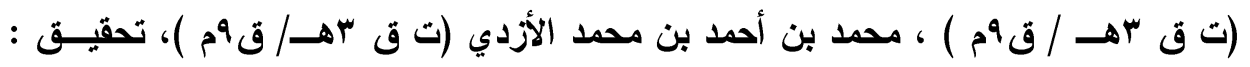

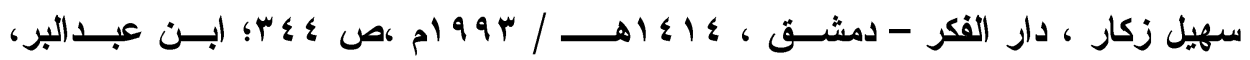

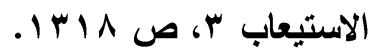

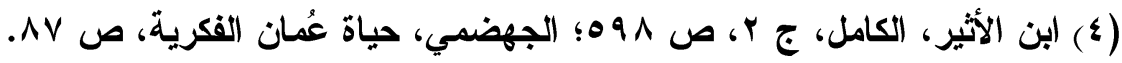


هي مكان تواجد هذا الصنم(1). وذات يوم قدّم مازن بن غضوبة(r) لذلك الصنم ذبيحة فسمع صوتًا يقول:

يا مازن أقبل إلي أقبل

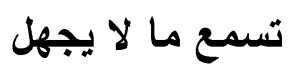

هذا نبي مرسل

جاء بحق منزل

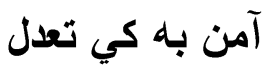

عن حر نار تشعل

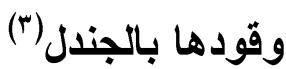

فتعجب مازن بن غضوبة لذلك، ثم ذبح بعد أيام قربانًا آخر، فسمع صوتا يقول: يا مازن اسمع تشر ظهرَ خير وبطن شر بعث نبي من مضر بدين الله الكبر

فذع نَميتّا من حجر

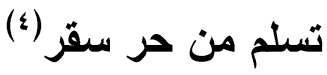

وفي هذه الأثناء قدم رجل من أهل الحجاز فسألوه "ما وراعك؟ فقال: ظهر رجل من

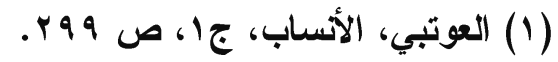

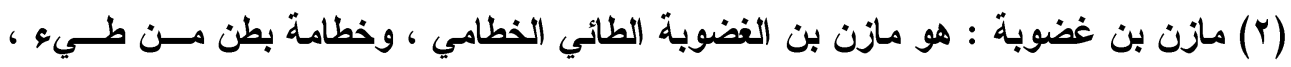

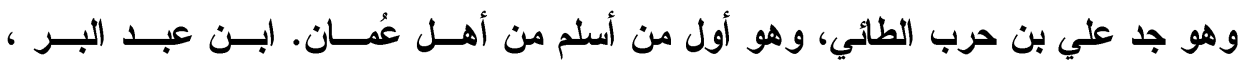

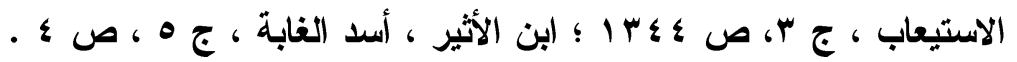

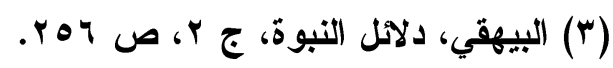

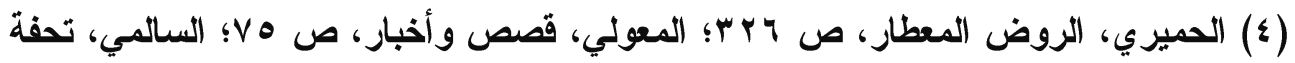

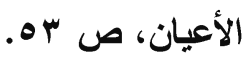




\section{الترقير الدولخ \\ ISSN 2356-9050}

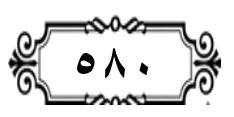

يقال له "أحمد" يقول لمن أتاه "(جيبوا داعي الله"(1)، فثار مازن إلى الصنم فكسره، وشد راحلته حتى أتى النبي صلى الله عليه وسلم بالمدينة المنورة وكان ذلك في سنة 7هـ / TV/م، فشرح الله صدره للإسلام فأسلم، ثم عاود مازن بن غضوبة مرة أخرى الوفود إلى المدينة المنورة للالتقاء بالنبي صلى الله عليه وسلم وكان ذلك في سنة Vه / Y T Tــ، وكان على رأس وفد من بني طيئ، ليطلع النبي

صلى الله عليه وسلم على ما استجد من تتابع دخول الناس في دين الإسلام(؟). ومن خلال ما سبق نرى أن مازن بن غضوبة وفد للقاء النبي صلى الله عليه وسلم مرة أخرى بصحبة وفد من قومه، إلا أنتا لم نتمكن من معرفة عددهم بالتحديل، وقد أوفدهم مازن بن غضوبة معه حرصًا منه على أن ينعموا معه مأه برؤية النبي صلى الله عليه وسلم والجلوس معه، وإرواءً لظمأ شوقه بلقائه صلى الله عليه وسلم تارة بعد تارة، وتلمسا لمعرفة ما نزل من الأكر الدكيم، وطلبًا للتفقه في الدين، ليصبح بذلك من أوائل الدعاة العُمانيين وأولهم إسلاما وصحبة. أما الوفد الثالث فكان على يد بنى طاحية؛ ففي أواخر السنة السادسة

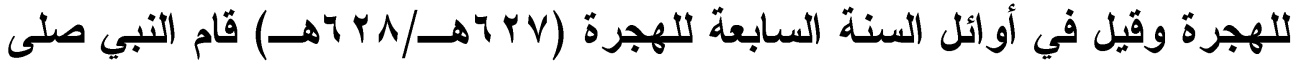
الله عليه وسلم بإرسال رسالة إلى ملوك وسلاطين الممالك من حول الجزيرة العربية، ومن بين رسله الأين أرسلهم رسوله لملك فارس كسرى أبرويز بن هرمز بن كسرى أنوشروان(")، ياعوه للإسلام، فلما وصله كتاب التبي صلى الله عليه وسلم قام بتمزيقه، فقال النبي صلى الله عليه وسلم لما بلغه خبر تمزيقه

$$
\begin{aligned}
& \text { (1) ابن الأثير، أسد الغابة، ج ه، ص ؛. }
\end{aligned}
$$

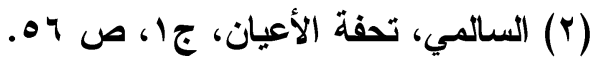

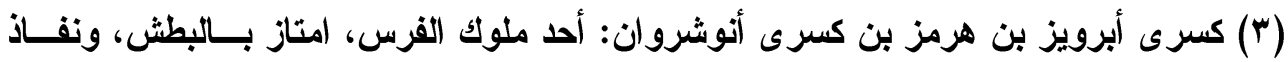

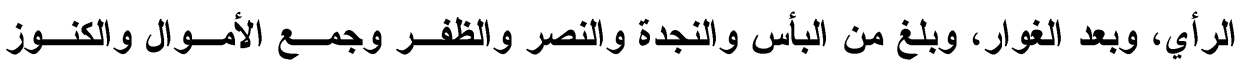

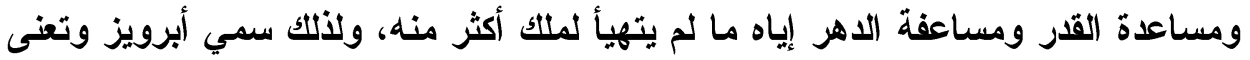

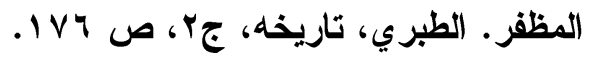

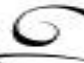


للكتاب(1): "مزّق الله ملكه"() فلم تمض على كسرى أيام حتى سلط الله عليه ابنه شيرويه فقتله نتيجة ثورة كبيرة ضد كسرى من داخل بيته بعد أن لاقت جيوشه هزيمة منكرة أمام جنود قيصر . ونتيجة لألك أبدى شيرويه اهتمامه بأمر النبي صلى الله عليه وسلم بعد جلوسه على كرسي الملك؛ حيث كان يخشى على نفسه ومملكته من هذا الرجل الأي يتسارع نجمه من ناحية الجزيرة العربية، فأمر عامل رعاياه من الفرس في

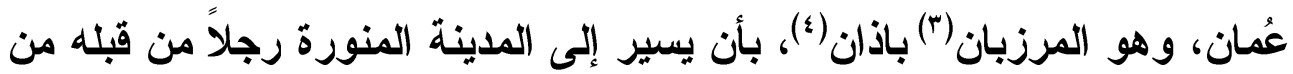
أجل أن يستطلع له أمر هذا النبي الأي ظهر في الجزيرة العربية ويأتيه بخبره، فوقع الاختيار على كعب بن برشة الطاحي للقيام بهذه المهمة حيث كان مجيدا للغة العربية والفارسية، وكان قارئًا لكتب أهل الكتاب، فاستجاب كعب بن برشة الطاحي لألك، فركب راحلته، وتوجه إلى الحجاز ليستطلع ويتحقق من خبر هذا الرجل، فلما وصل إلى المدينة المنورة أتى التبي صلى الله عليه وسلم فدار بينهما حوار استثف من خلاله الصفات التي حفظها من الكتب، فعرض عليه النبي صلى التى الله عليه وسلم الإسلام فأسلم، ولما عاد كعب بن برشة الطاحي إلى صحار أتى باذان وأخبره أن الرجل نبي مرسل، وأنه قد صدقه وآمن به(ه).

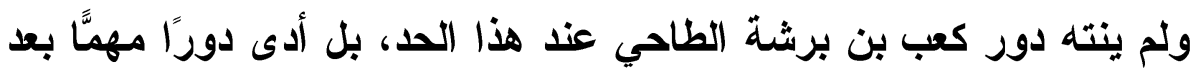
ذلك؛ حيث سعى إلى دعوة قومه للاخول في الإسلام، فاستجاب له قومه فدخلوا في دين الإسلام، مما مهد الطريق أمام قبائل صحار وغيرها من البلان بعد ذلك

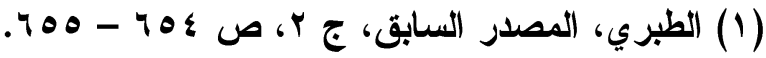

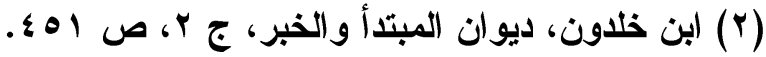

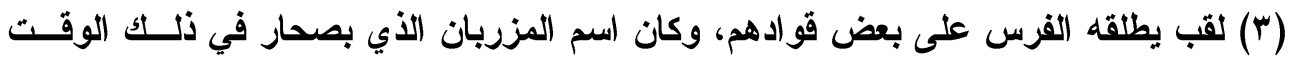

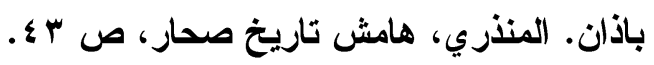

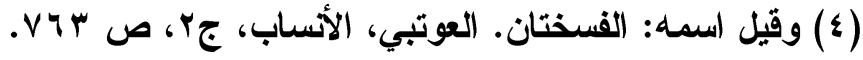

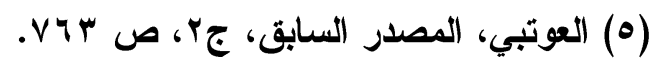

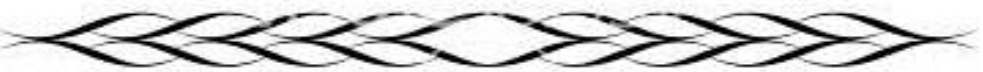




\section{الترقير الدولخ \\ ISSN 2356-9050}

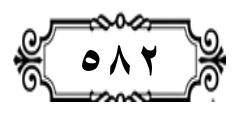

للخروج لملاقاة التبي صلى الله عليه وسلم، فمن أثهر تلك الوفود وفد بني طاحية الثاني برياسة أسد بن يبرح الطاحي(')، وهو يُعد الوفد الرابع الذي قدم إلى لئ

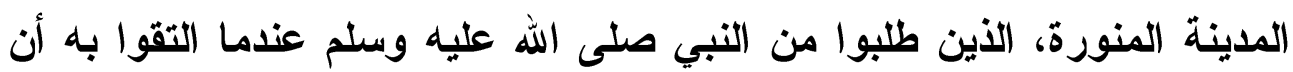
يبعث لهم رجلا يعلمهم أمور دينهم، فبعث معهم مخرمة العبدي(r)، فنهب معهم إلى عُمان ليعلمهم أمور دينهم (ّ). وفي سنة ^هـ/9 \آم بعث النبي صلى الله عليه وسلم عمرو بن العاص وأبا زيد الأنصاري بكتاب إلى جيفر وعبد ابني الجلندي الأزدي بعُمان(؛) بدعوهما

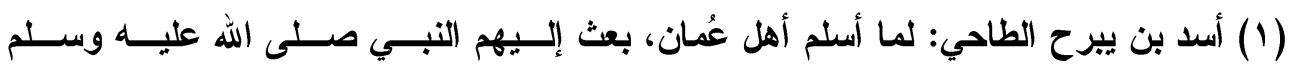

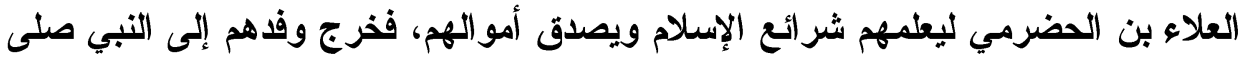

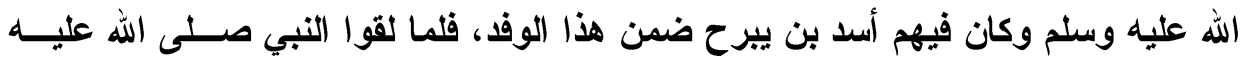

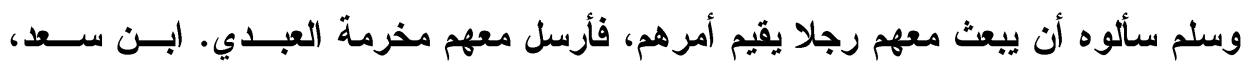

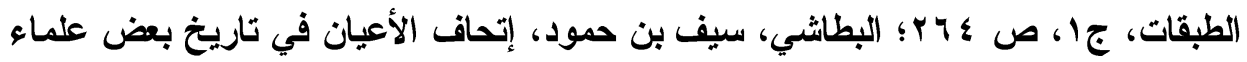

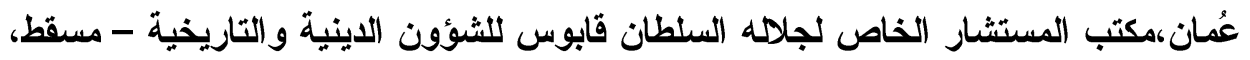

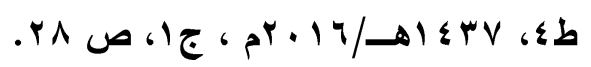

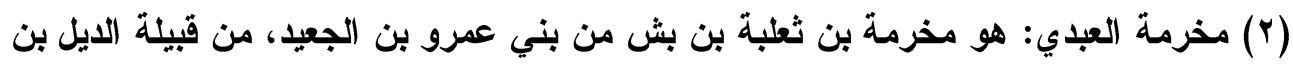

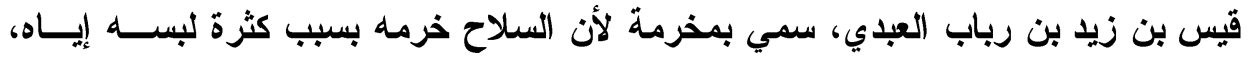

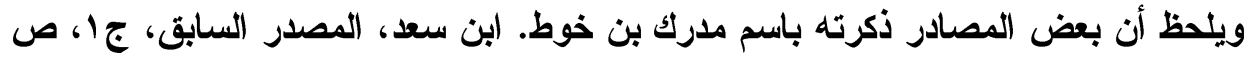

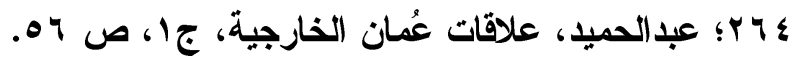

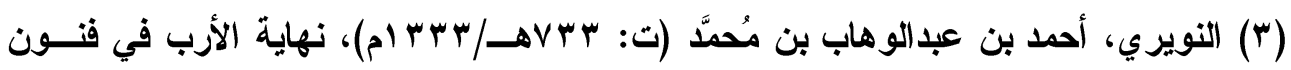

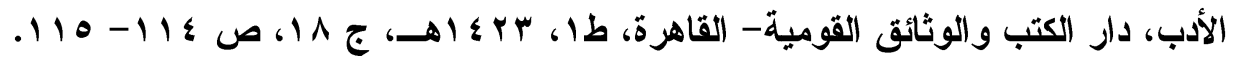

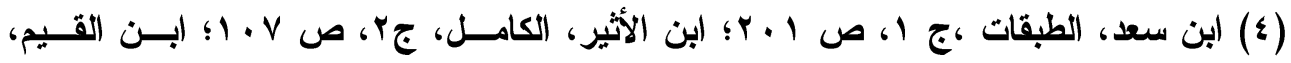

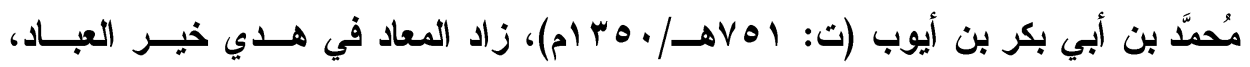

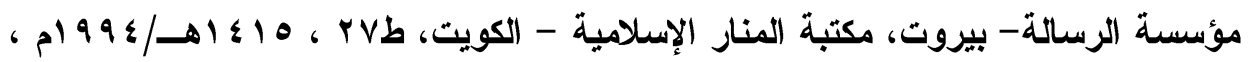

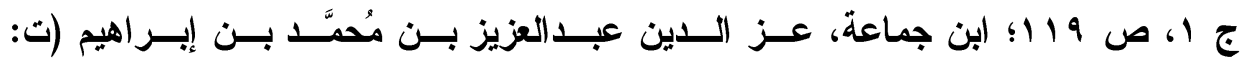

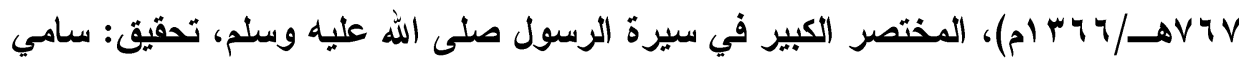

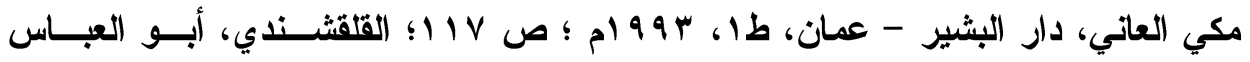

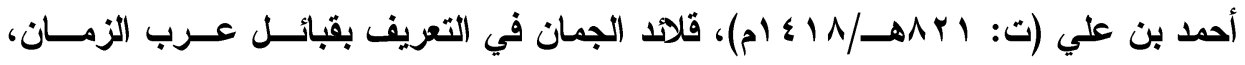

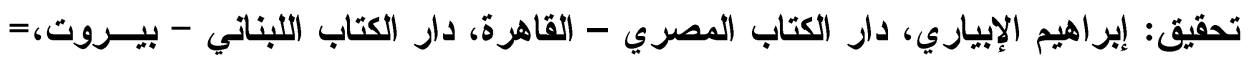

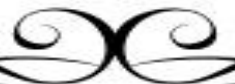


للإسـلام، فأسلما وصدقا(')، فأرسل جيفر إلى جميع نواحي عُمان، يدعوها للاخول في الإسلام، فأجابوه إلى ذلك إلا الفرس، فحاربهم أهل عُمان وطردوهم من

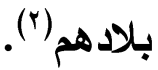

وخلال هذه الأثناء تتابع قدوم الوفود إلى المدينة المنورة؛ ومنهم وفد سلمة بن عياذ الأزدي(ّ) في أناس من قومه(؛)، ثم جاء وفد ثمالة برياسة عبدالله بن علس الثمالي، ووفد بنى الحدان بن شمس برياسة مسلية بن هزان الحداني(•)، وبصحبتهما عدد من رجالات قومهما، وكاتت وفادتهم بعد فتح مكة

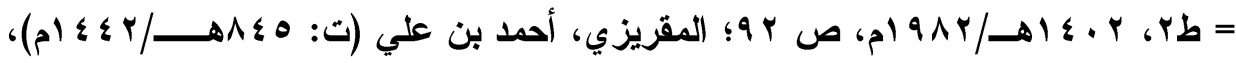

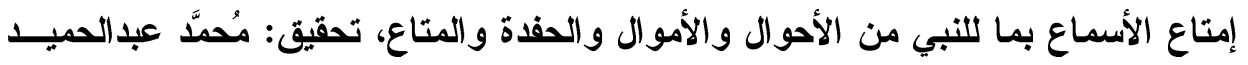

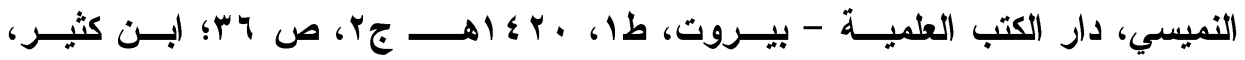

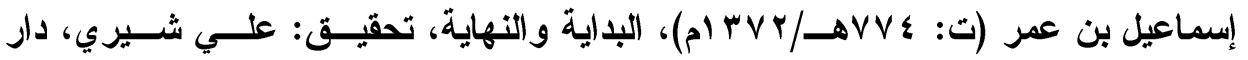

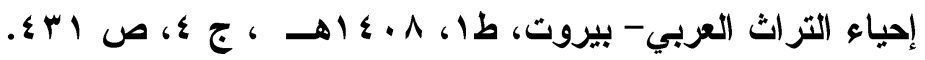

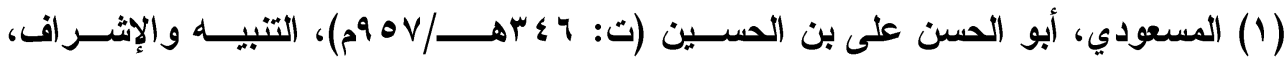
تصحيع: عبدالله إسماعيل الصاوي، دار الصاوي - القاهرة، د.ت، ص · ع ب؛ ابــن الأثبــر،

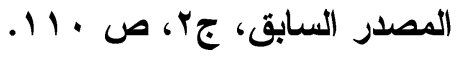

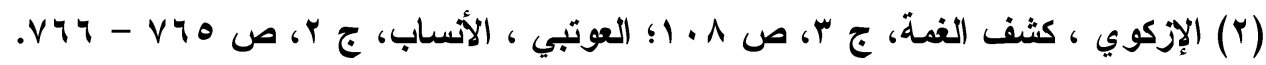

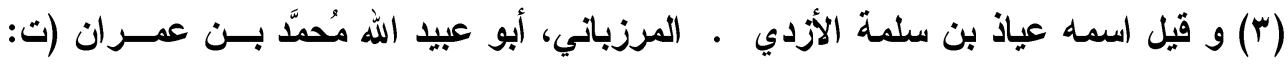

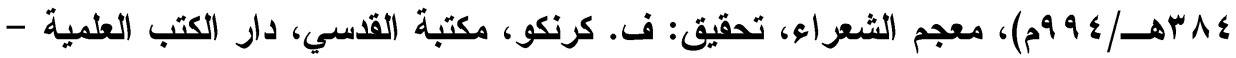

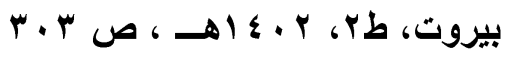

(ع) ابن سعد، الطبقات، جا، ص ع צr؛ علي، جواد، المفصل في تاريخ العرب قبل الإسـلام،

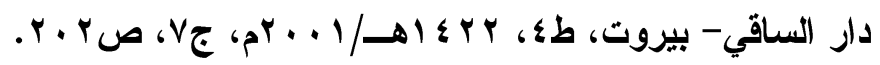

(•) عبد الله بن علس الثمالي: وفد هو ومسلية بن هزان الحداني، في مجموعة من قومهــا، على رسول الله صلى الله عليه وسلم بالمدينة المنورة، فأسلموا وبايعوا التبـي صــلى الله عليه وسلم على قومهم، وكتب لهم كتاباً بما فرض عليهم من الصدقة في أمسـوالهم. ابـن

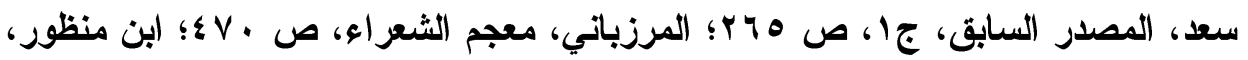

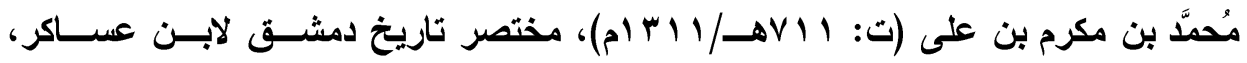

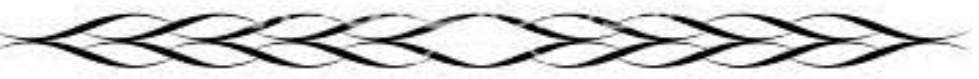


المكرمة(1)، فأسلموا وبايعوا رسول الله صلى الله عليه وسلم وكتب لهم كتابًا بما فرض عليهم من الصدقة في أموالهم(r)، ثم جاء وفد أبي صفرة العتكي العُماني (ז)، فذخل أبو صفرة على رسول اللَّه صلى الله عليه وسلم على أن يبايعه، وعليه حلة صفراء، وكان ذا قامة طويلة، يتسم بالجمال والفصاحة فلما رآه النبي صلى الله عليه وسلم أعجبه ما رأى منه، فقال له: 》من أنت؟ه قال: أنا قاطع بن لن سارق بن ظالم بن عمر بن شهاب بن الهلقام بن الجلند بن السلم الّأي كان يأخذ كل" سفينة غصبا، أنا الملك بن الملك. فقال له النبي صلى الله عليه وسلم: 》أتت أبو صفرة، دع عنك سارقا وظالماه. فقال: "أشهر أن لا إله إلا اللَّه وأنك عبده

ورسوله حقا"(ז).

تحقيق: روحية النحاس، رياض عبدالحميد مراد، مُحمَّد مطيع، دار الفكر - دمثـق، طا،

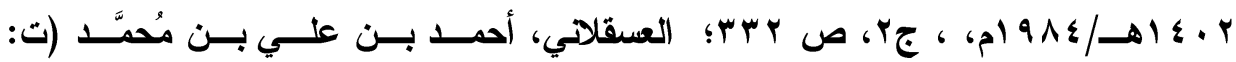

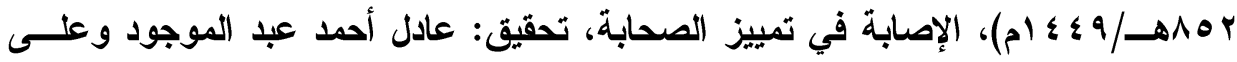

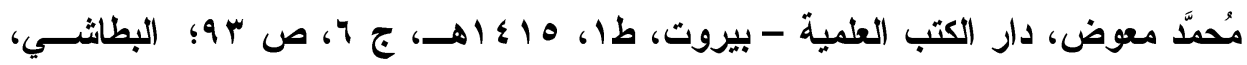

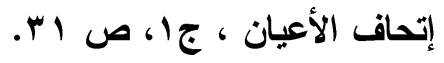

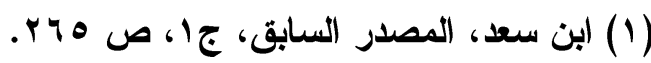

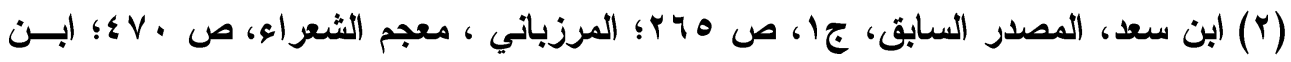

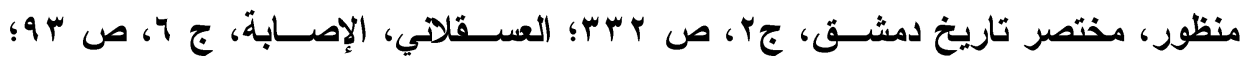

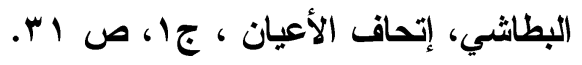

(T) أبو صفرة العتكي العُماني: اسمه ظالم بن سراق بل بن صبح الأزدي، من أزد دباء، وقد كانوا

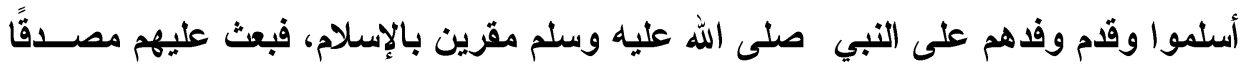

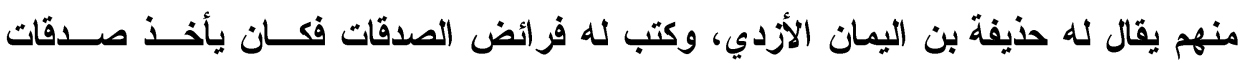

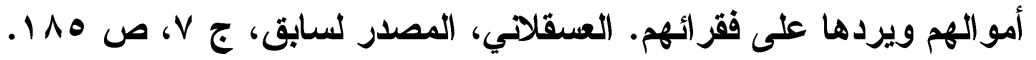

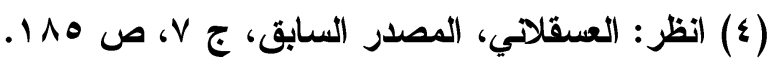


ثم جاء وفد صحار بن العبّاس العبديّ(')، فدخل على التبي صلى الله عليه وسلم وأسلم(؟)، ثم جاء وفد حمامي بن جرو الفراهيدي العماني(ّ)، وهو من أجداد

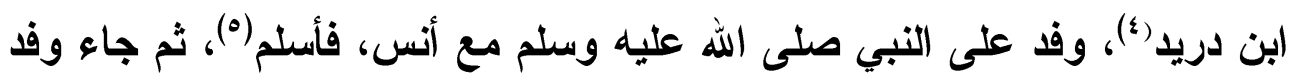

(1) صحار بن العباس: اثتهز بطلم الأساب، والخطابة، روى عن النبي صلى الله عليه وســلم

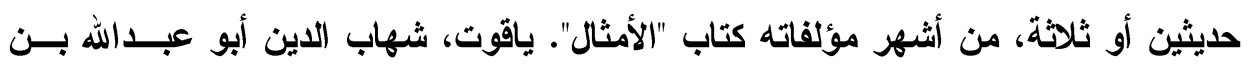

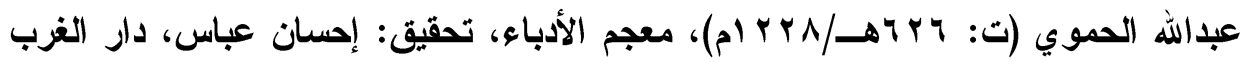

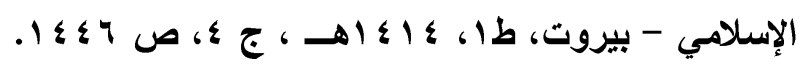

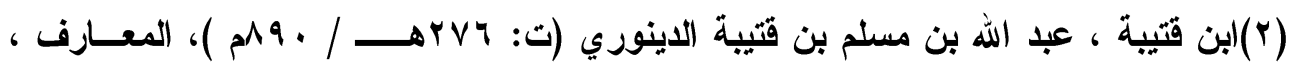

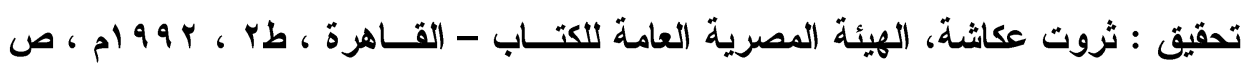

q

(r) حمامي بن جرو الفراهياي: هو الصحابي حمامي بن جرو بــن واســـع بـن ســلمة بــن

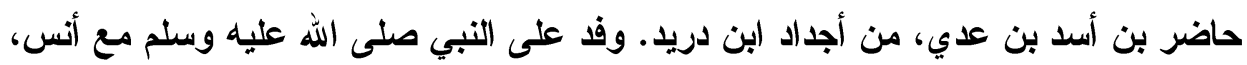

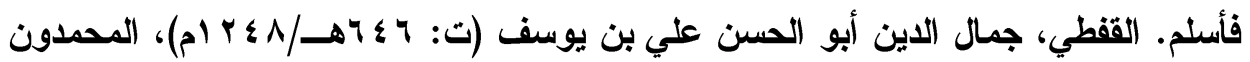

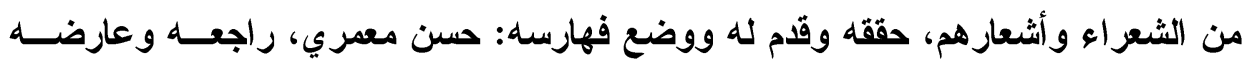

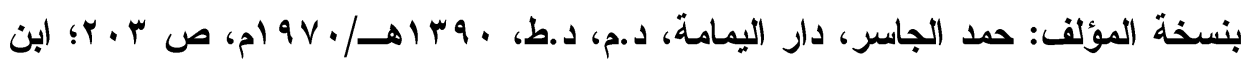

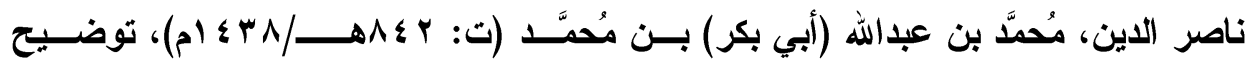

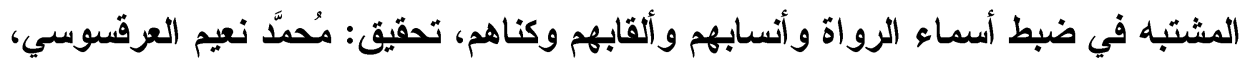

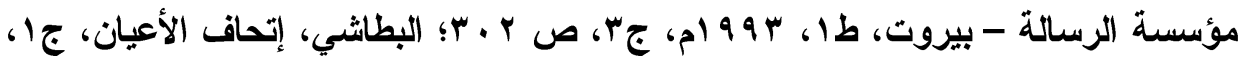
صهr.

(؛)(ابن دريد: هو أبو بكر محمد بن الحسن بن دريد بن عتاهية بن حنتم بن حسن بن حمـامي

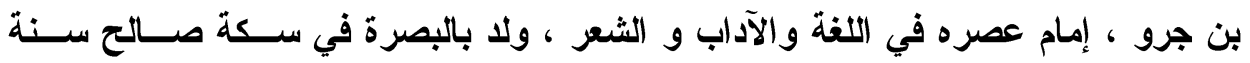

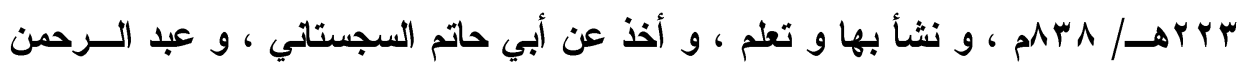

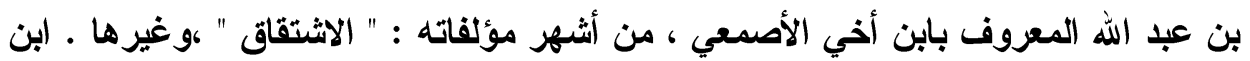

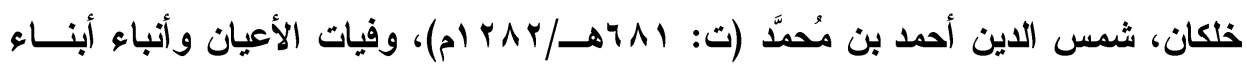

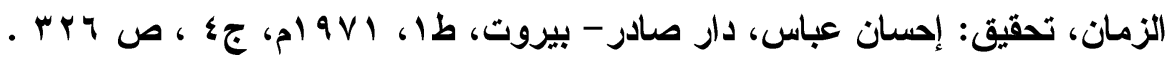

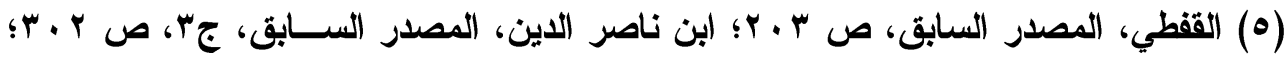

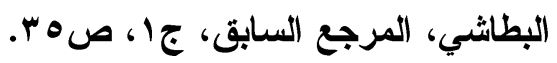




\section{الترقير الدولخ}

ISSN 2356-9050

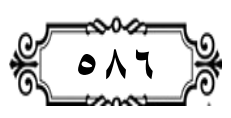

حولية كلية اللغة العربية بجرجا مجلة علمية محكمة

حذيفة بن محصن الغلفاني(') -الذي وفذ على النبي صلى الله عليه وسلم وكان من صحابته- وكان برفقته عبدالله بن وهب الزاسبي(r) وجابر بن عبدالله

الر اسبي(")، أبو وزاع الراسبي رضي الله عنه (ع).

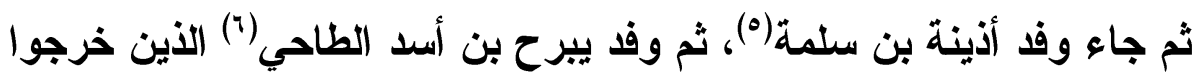

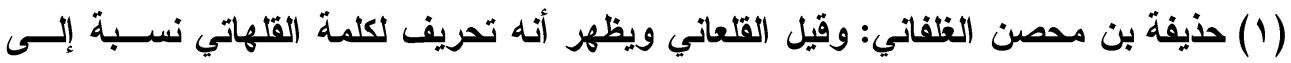

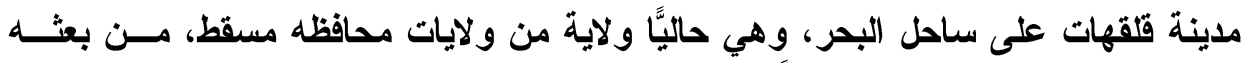

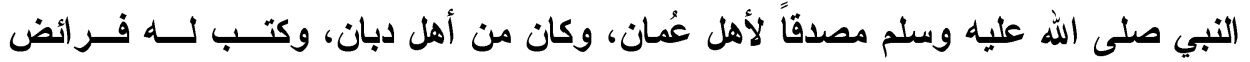

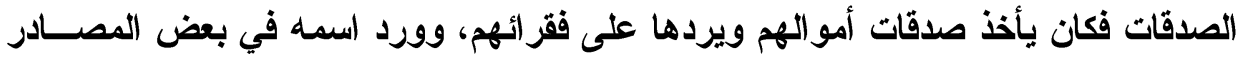

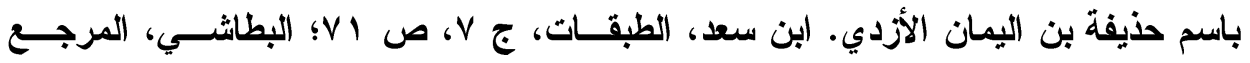

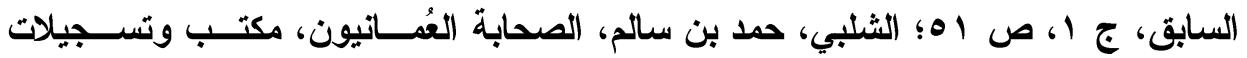

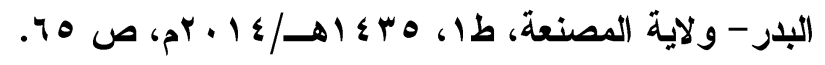

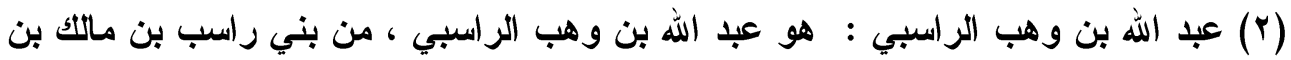

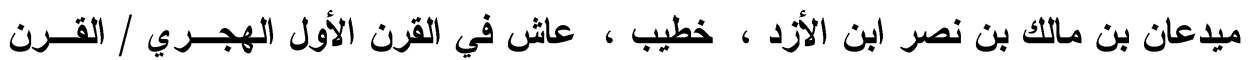

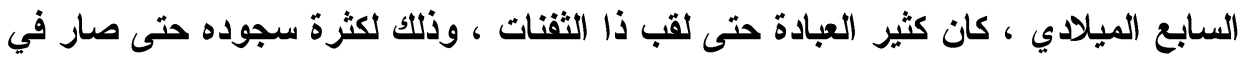

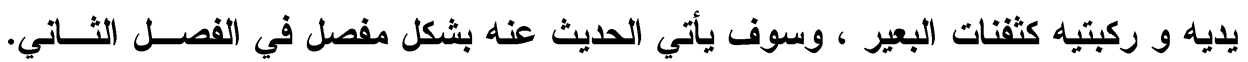

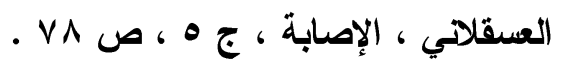

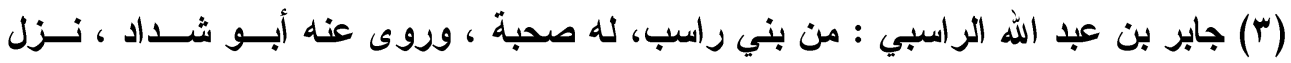

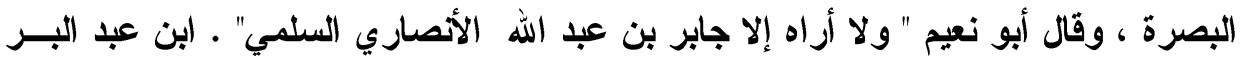

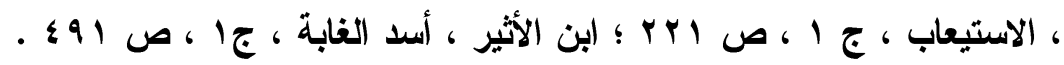

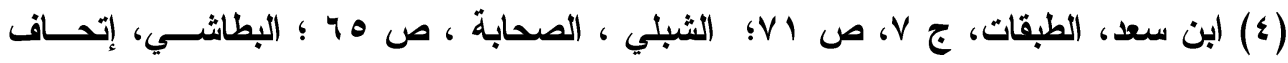

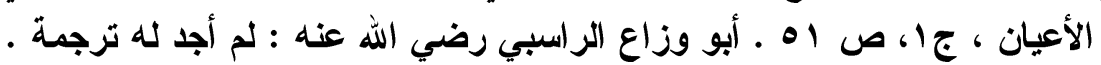

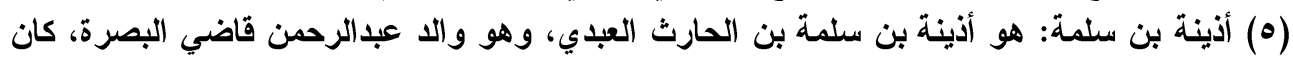

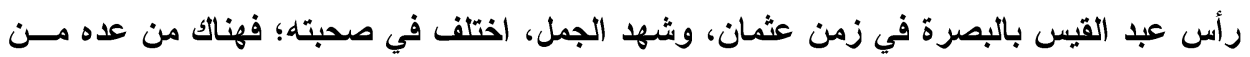

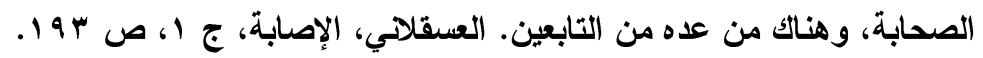

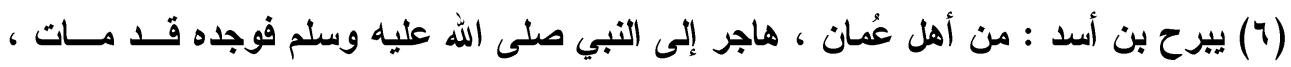

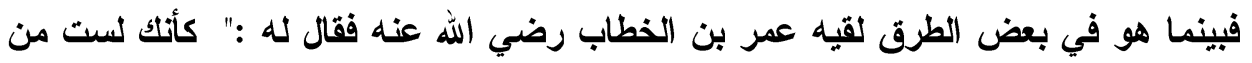

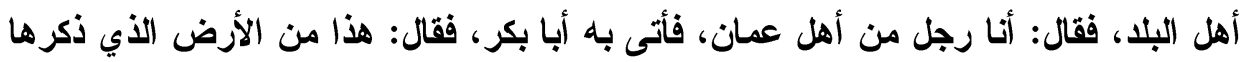

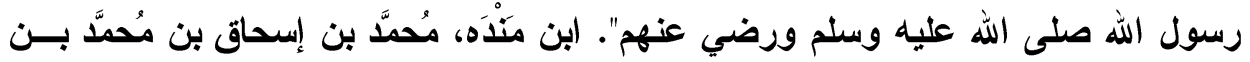

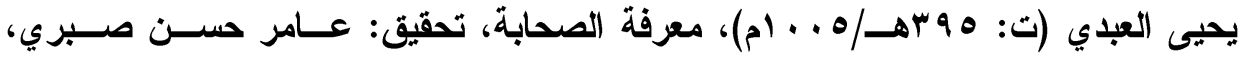

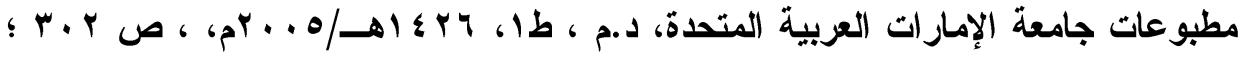

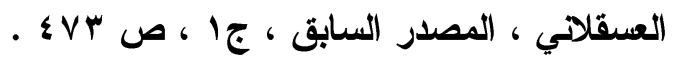


من صحار متوجهين إلى المدينة المنورة لملاقاة النبي صلى الله عليه وسلم إلا أنهم وصلوها والنبي صلى الله عليه وسلم قد توفي، وهناك من قال بأن يبرح قد وصل المدينة والنبي صلى الله عليه وسلم لم يُقبر بعد، وقد رآه في حال موته؛ حيث كان الصحابة يُخلون عليه الناس أرسالا للصلاة عليه وتوديعه، فتثبت صحبته من هذا الباب، وإن لم يجالسه ويتكلم معه('). بعد ذلك وفد عقبة بن النعمان(r) على النبي صلى الله عليه وسلم ولكنه لم

يدركه لأن النبي صلى الله عليه وسلم قد مات بَّ. ولم تقتصر تلك الوفود على الرجال، وإنما أوفدوا نساءهم؛ وذلك كي يلتقين بأمهات المؤمنين ويقمن بزيارتهن؛ حيث يذكر أن نسوة من أهل عُمان استأذن على عائشة -رضى الله عنها- فأذنت لهن، فلخلن وسلمن عليهاءئ. أما بعد وفاة التبي صلى الله عليه وسلم فقد استمرت الوفادات إلى المدينة المنورة، ومن أهمها الوفد الكبير الأي صحب عمرو بن العاصنيك إلى المدينة المنورة بعد وفاة النبي صلى الله عليه وسلم والأي يعد حلقة من حلقات التواصل العلمي؛ لما يضمه ذلك الوفا من قيادات سياسية وفكرية، ويدل على ذلك تلك الكلمة الفصيحة التي تبادلها الوفد مع خليفة رسول الله صلى الله عليه وسلم أبي

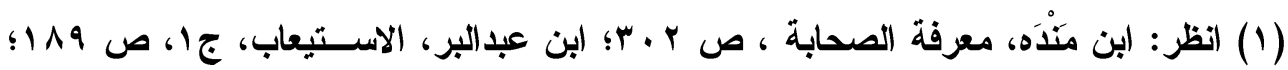

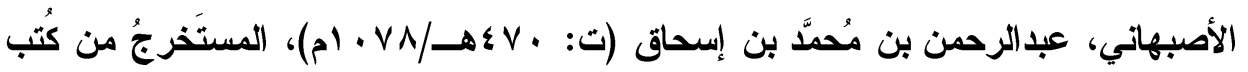

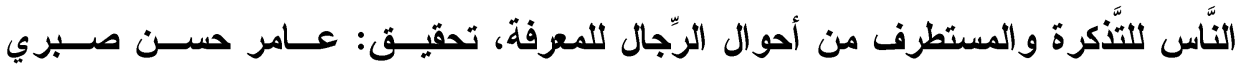

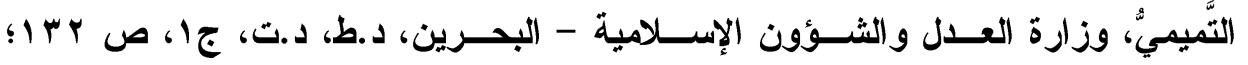

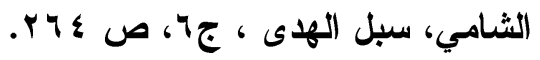
(Y) عقبة بن النعمان العتكي، من أهل عُمان، أتى النبي صلى الله عليه وسلم حين مات، وشيّع

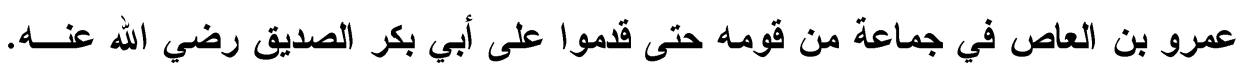

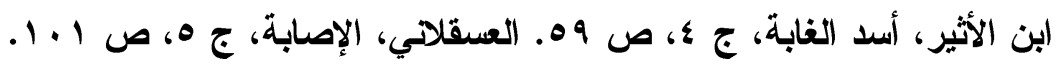

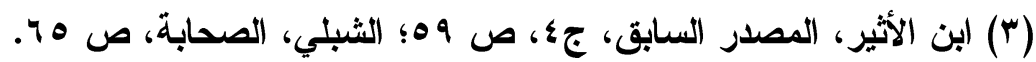

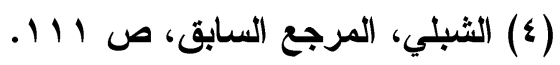




\section{الترقير الدولخ}

ISSN 2356-9050

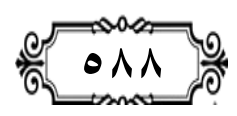

بكر الصديق رضي الله عنه؛ حيث ضم ذلك الوفد نحو سبعين فارسنًا، على رأسهم أحد ملكي عُمان وهو عبد بن الجلندي، ويضم أيضًا جيفر بن جثم العتكي(') ، وأبا صفرة، وحمامي بن جرو بن واسع بن وهب(ז)، وعندما وصل عمرو بن العاص إلى المدينة المنورة، التقى الوفد العُماني المصاحب لعمرو بالخليفة أبي

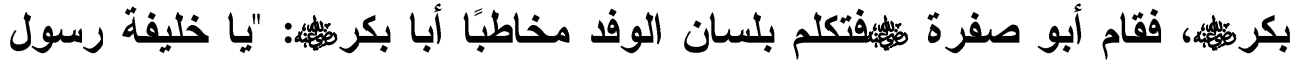
الله ويا معشر قريش هذه أمانة كاتت في أيدينا وفي ذمتنا وديعة لرسول الله صلى الله عليه وسلم فقد برئنا منها إليك، فقال أبو بكر : جز اكم الله خيرا"("آ. ولقد شهدت العديد من الدول الإسلامية انتشار العديد من الفرق الإسلامية؛ حيث وقعت الكثير من الاختلاقات في الإسلام -كغيره من الثرائع السماويةبعضها في الأصول: وخاصة في موضوع علم الكلام، في أربع قواعد منه؛ وهي الصفات والتوحيد، والقضاء والقدر، والوعد والوعيد، وأخيرًا التبوة والإمامة،

(1) جيفر بن جشم العتكي : لم أجد لله ترجمة .

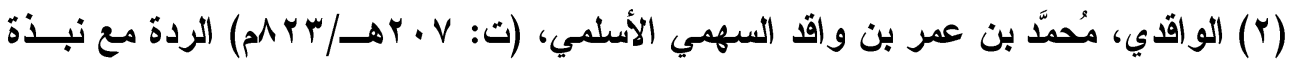

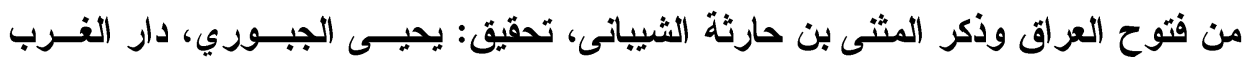

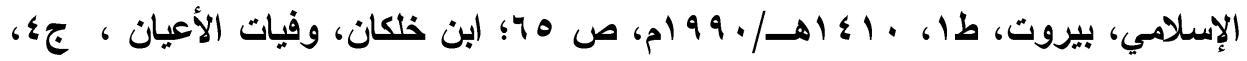

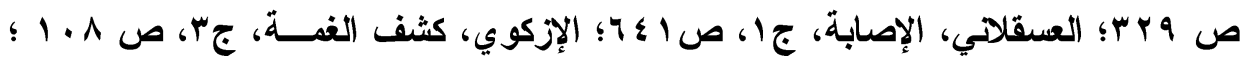

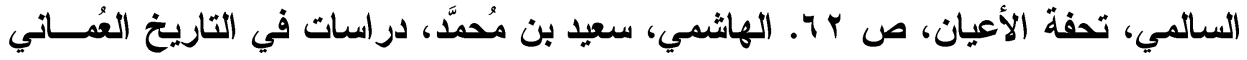

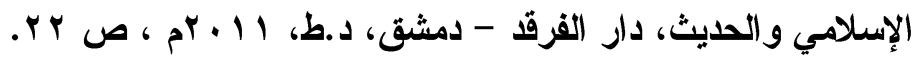

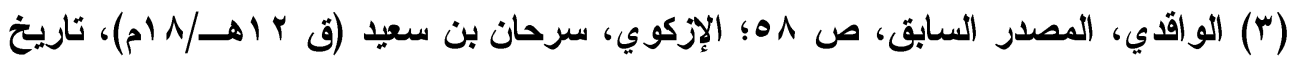

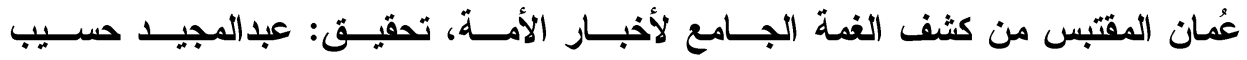

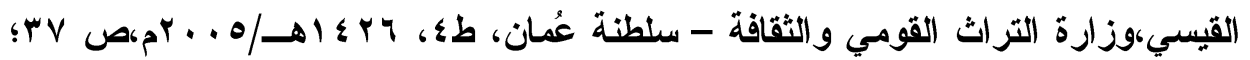

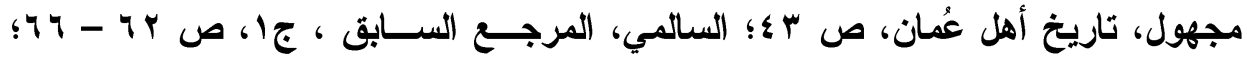

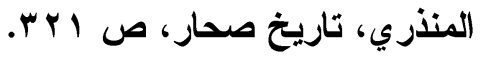

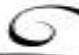


و البعض الآخر في الفروع وهي في علم الفقه(1).

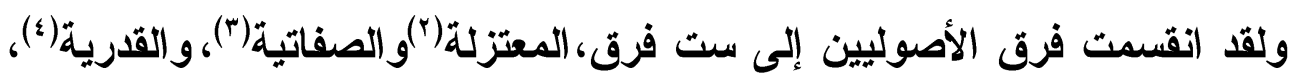

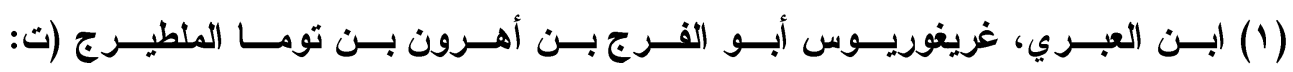

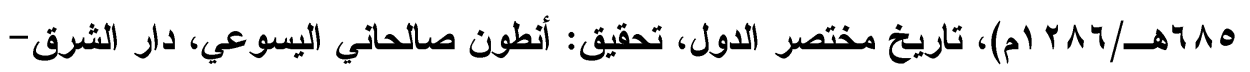

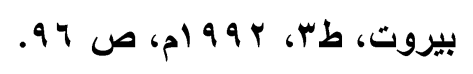

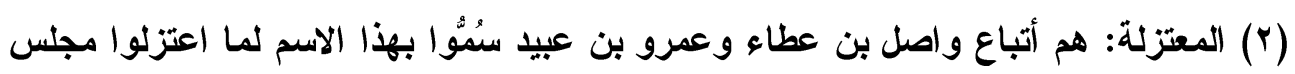

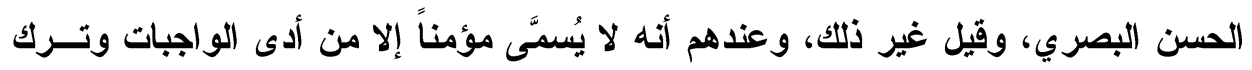

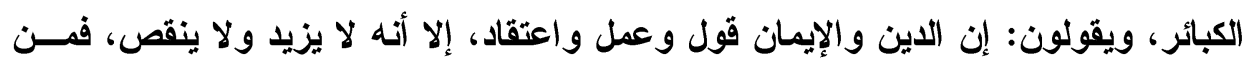

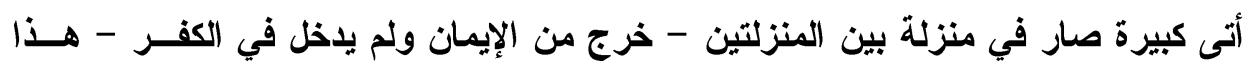

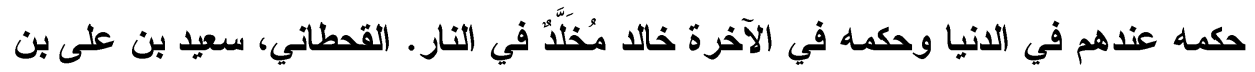

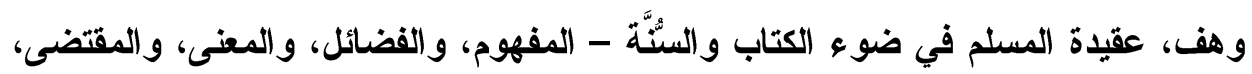

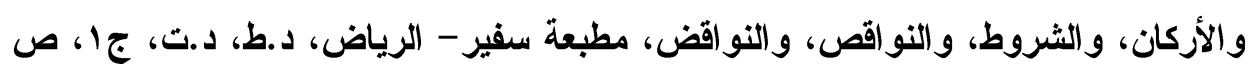
.119

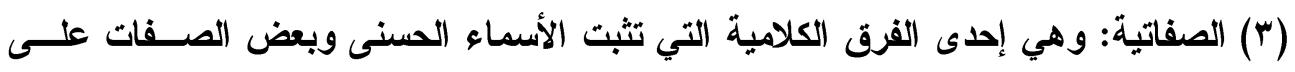

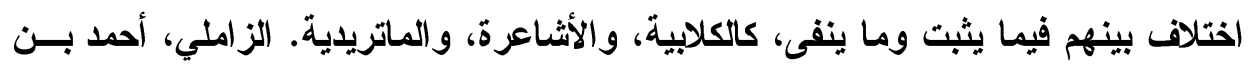

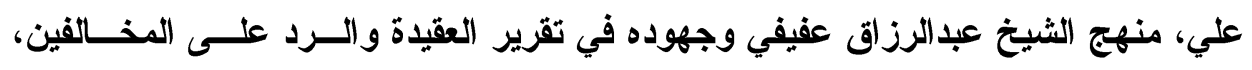

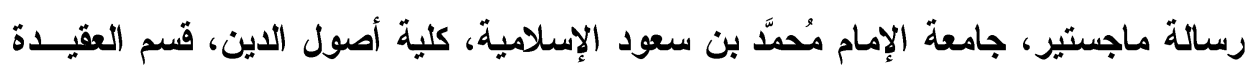

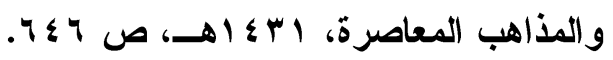

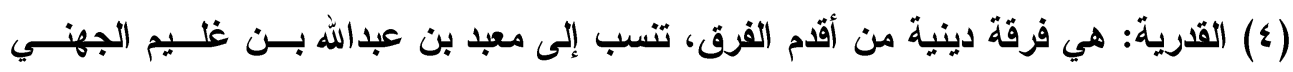

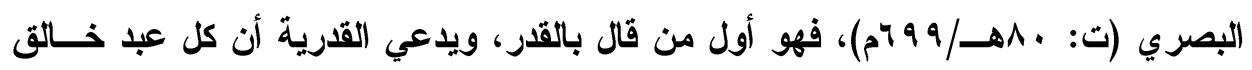

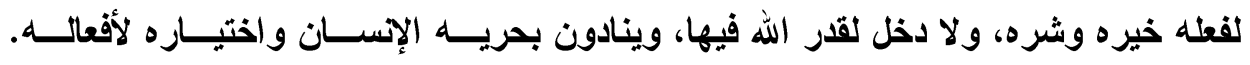

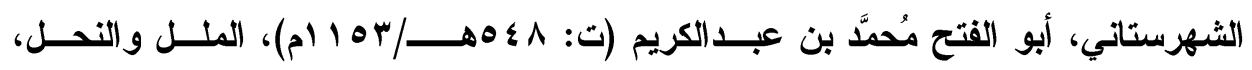

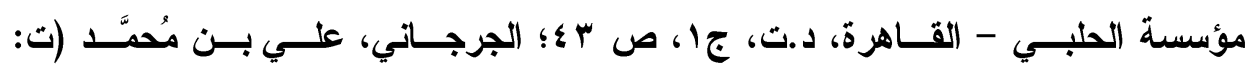

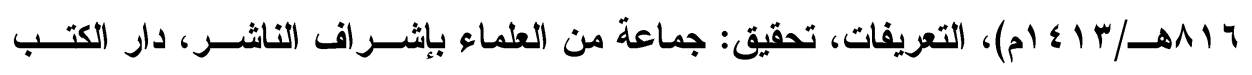

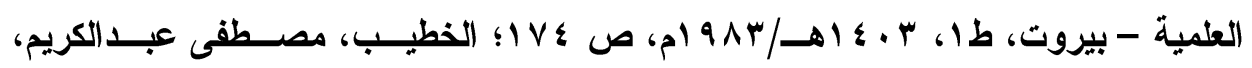

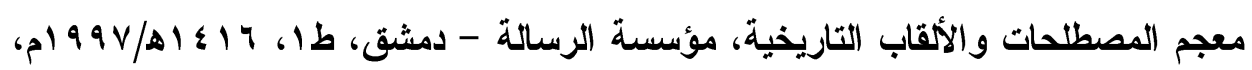

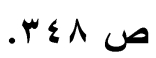

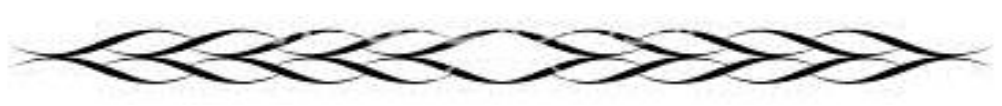




\section{الترقير الدولخ \\ ISSN 2356-9050}

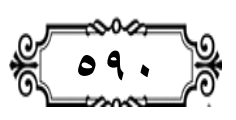

والجبرية (1)، والمرجئة(r) و الثيعة(")، ويتشعب عن كل فرقة أصناف تصل بها إلى ثلاث وسبعين فرقة؛ حيث ثبث عن التبي صلى الله عليه وسلم قوله:

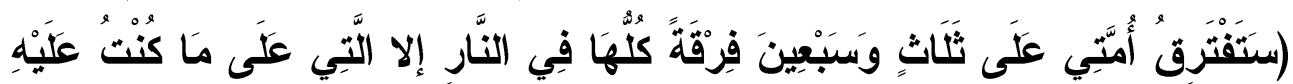

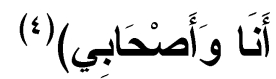

(1) الجبرية: إحدى الفرق الإسلامية، قالت إن الأفاعيل من الله؛ أي أن القدر خيره وشره من

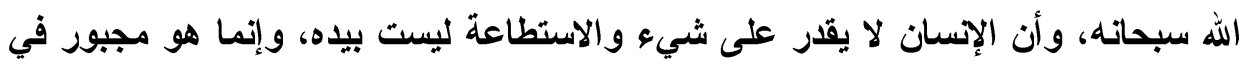

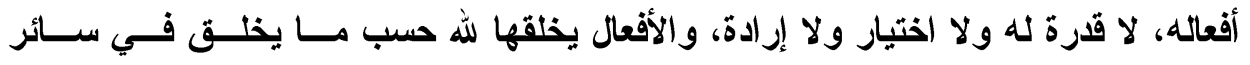

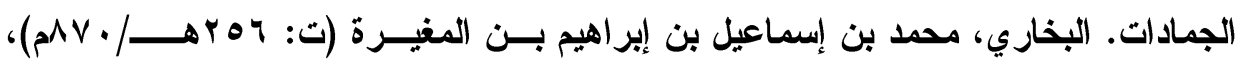

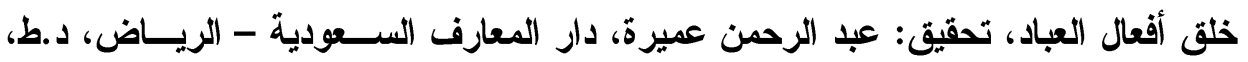

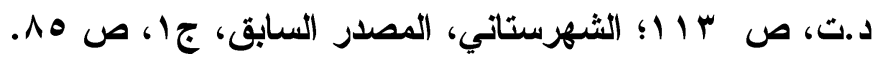

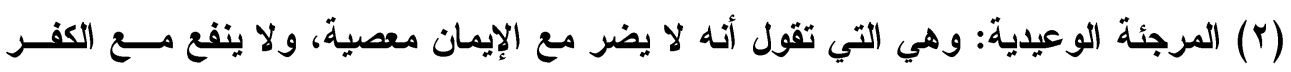

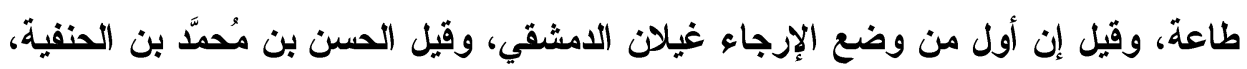

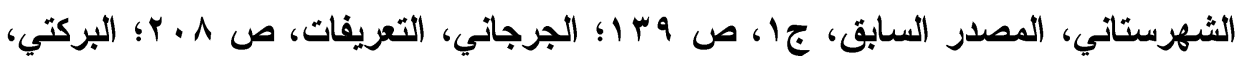

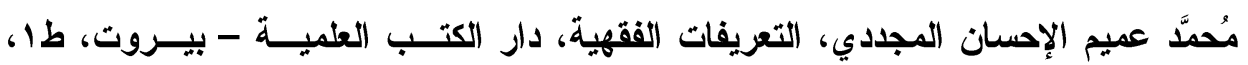

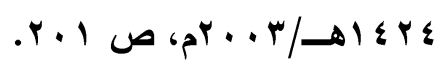

(ए) الثيعة: هم أقدم المذاهب السياسية الإسلامية، ظهروا في آخر عهل عثمان رضي الله عنه

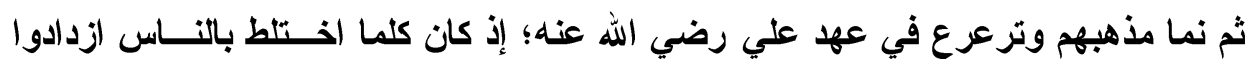

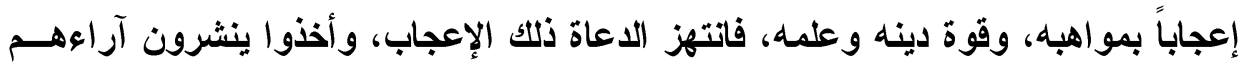

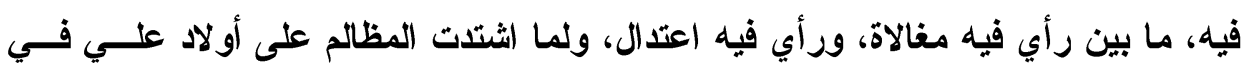

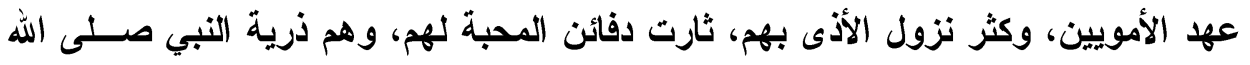

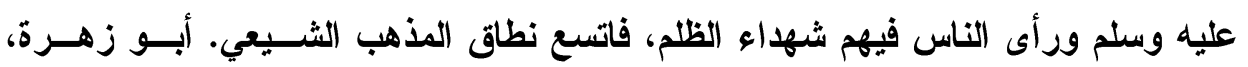

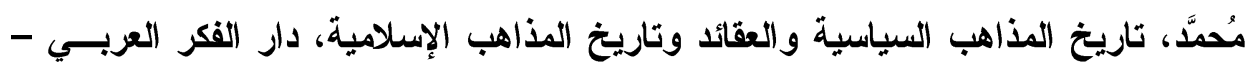

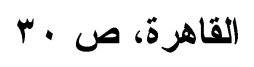

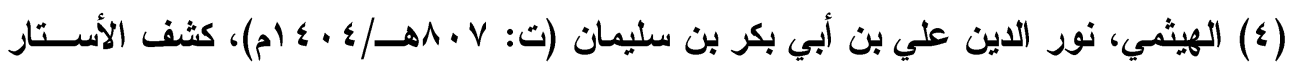

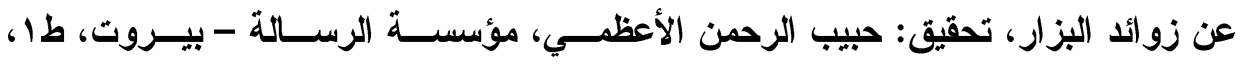

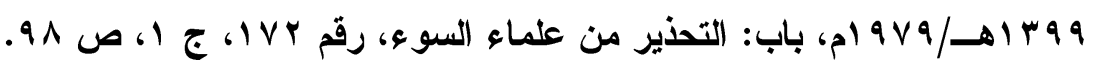

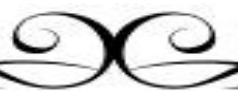


وشهدت عُمان في نهاية القرن الثالث الهجري/القرن التاسع الميلادي تفشي

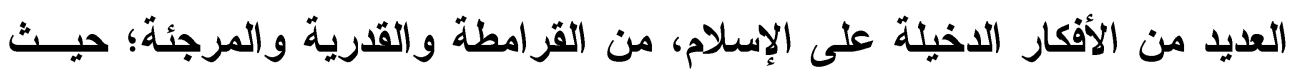

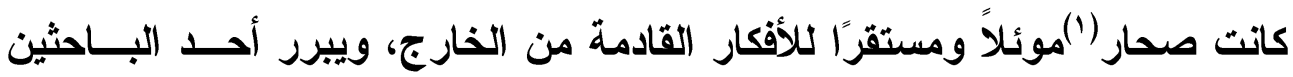
احتضان صحار لهذه الأفكار ببقائها مفتوحة الأبــواب لمختلــف الأجنــاس مــن

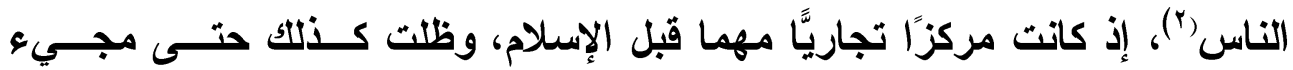

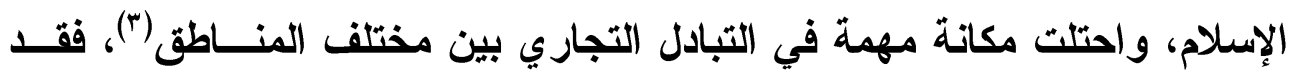
كانت "دهليز الصين وخزنة الشرق و العراق ومغوثة اليمن"(؛). وعلى الرغم من أن المصادر لا تفيدنا بالكثير من المعلومات عن هذه المذاهب الاخيلة، إلا أنها تؤكد انتثار المذهب الإباضي بين أهلها، وفي حقيقة الأمر فقد وقف أهل عُمان موقف المعارض من تثرب الأفكار الخارجية إليهم منذ وقت مبكر، فتنكر المصادر التاريخية موقفه الحازم ضد تشرب أفكار النجدات(ه)،

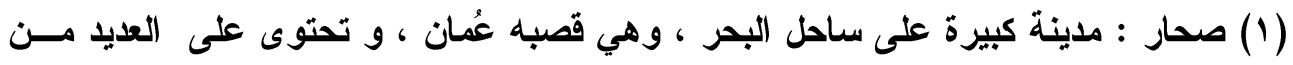

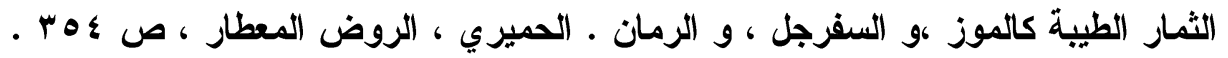

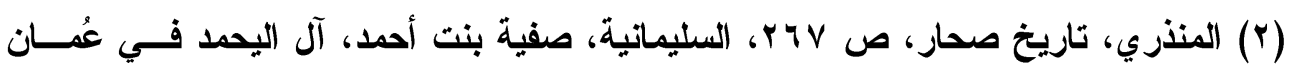

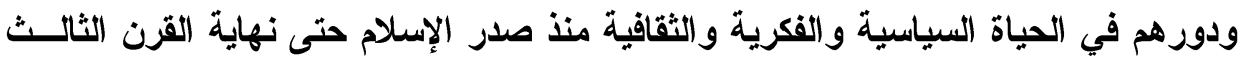

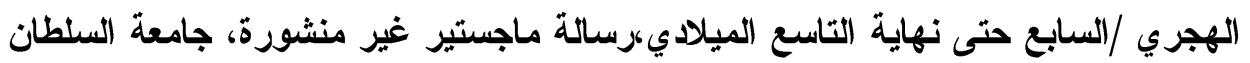

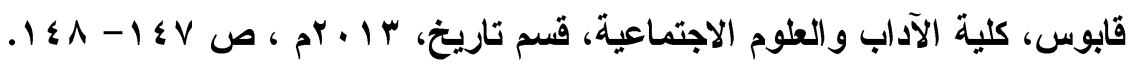

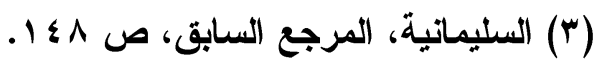

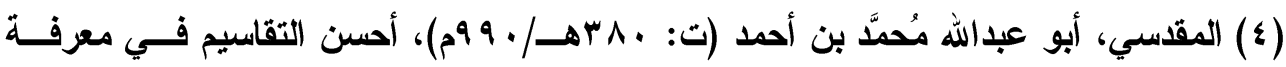

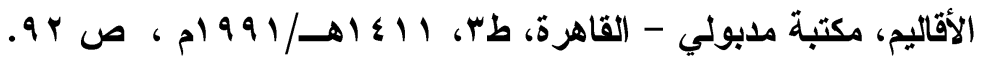

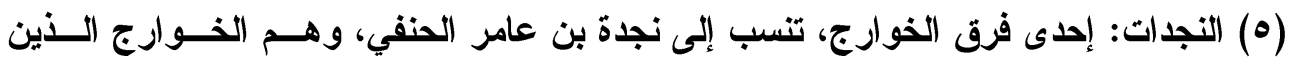

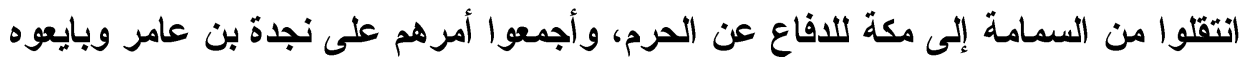

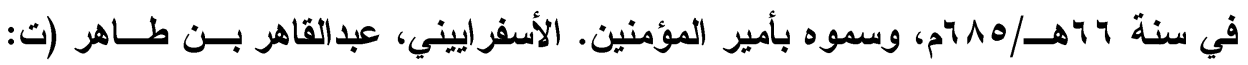

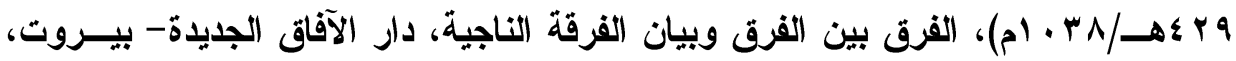

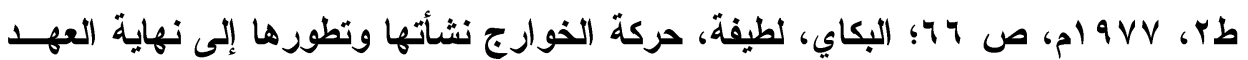

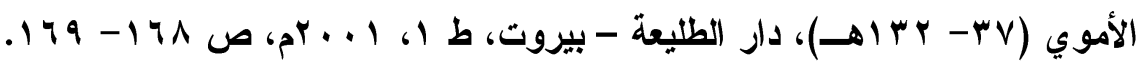




\section{الترقير الدولخ}

ISSN 2356-9050

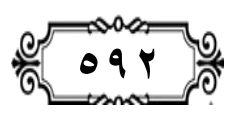

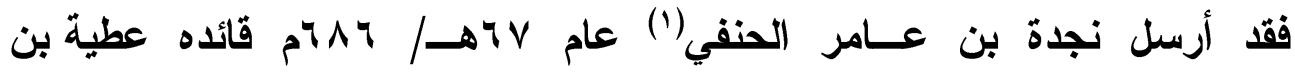
الأســــــود الحنفي(؟) لضم عُمان إلى دولته التي أنثأها في منطقة اليمامة وشرقي الجزيرة العربية، وعلى عُمان في ذلك الوقت عباد بن عبدالله الجلندي، ويعاونه ولاه سعيد وسليمان(")، ولقد استطاع عطية دخول عُمان بعد أن تمكن

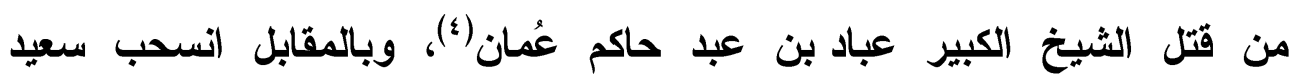
وسليمان إلى المناطق الأخلية، وبقي نجدة في عمان عدة أثهر ليعود بعدها إلى اليمامة مستخلفا عليها أبا القاسم، فانتهز العُمانيون فرصة رجوعه ليجمعا

(1) نجدة بن عامر : هو نجدة بن عامر الحروري الحنفي من بني حنيفة، إليه تنســب الفرقــة

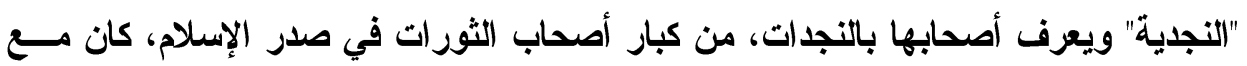

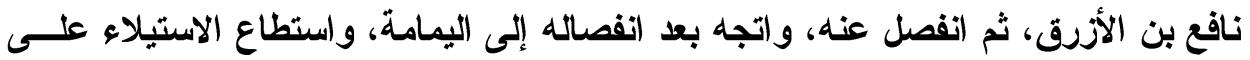

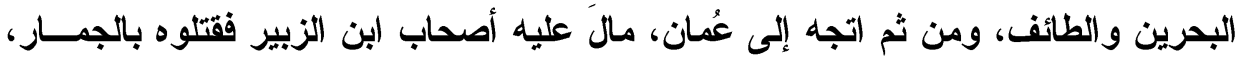

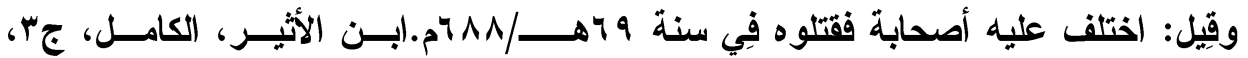

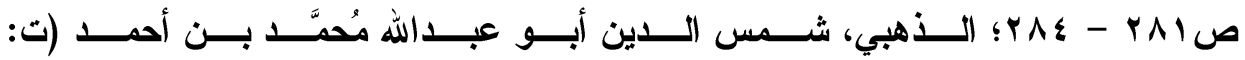

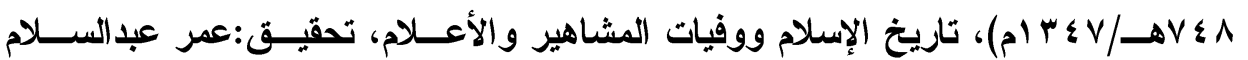

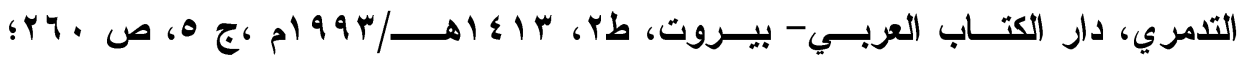

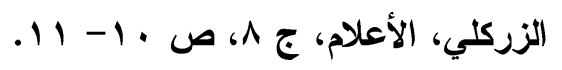

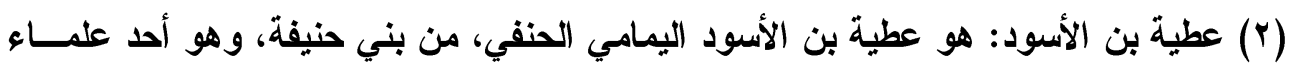

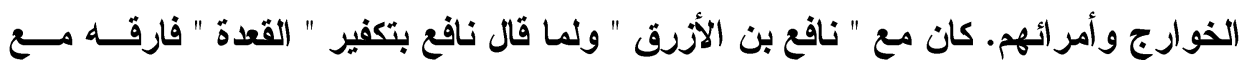

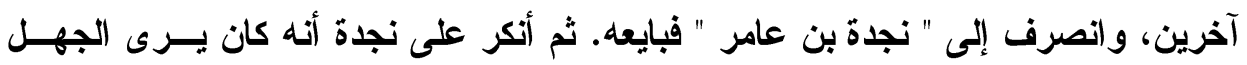

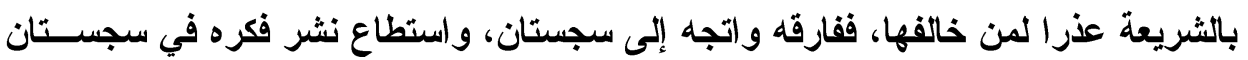

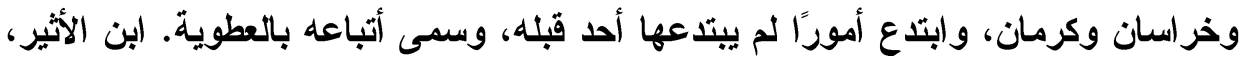

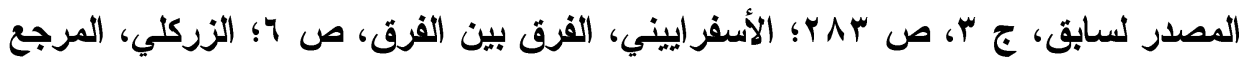
السابق، ج \&، ص V ₹ r.

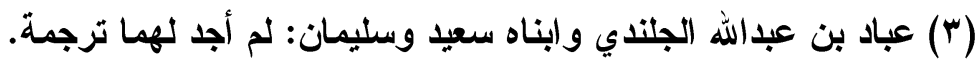

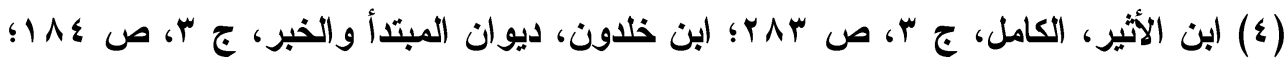

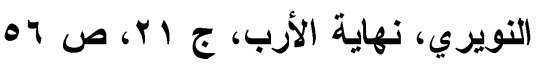

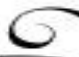


كلمتهم حول سعيد وسليمان أبناء عباد؛ حيث استطاعوا قتل أبي القاسم والقضاء

على أتباعه وإعادة الأمور إلى ما كاتت عليه قبل مجيئهم (1). وفي الجانب الآخر حدث خلاف بين نجدة بن عامر وقائده عطية بن الأسود فترك عطية اليمامة متجهًا إلى عمان ليتفاجأ بمقتل خليفته أبي القاسم والقضاء بله على أتباعه، وباعت محاولة دخوله إليها بالفشل ليثد رحله إلى كرمان بلانلا عندd)

تؤكد المصادر التاريخية عدم تقبل العُمانيين لأفكار الخوارج المتطرفين؛ حيث وجدت- الصفرية-في عمان أرضا خصبة، إلا أن أهل عُمان قاموا

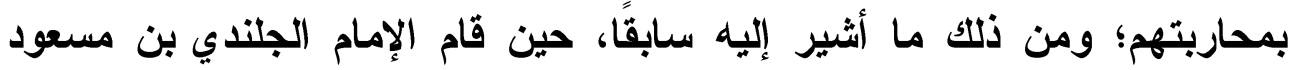
بمحاربة شيبان الصفري عند مقدمه لُعُمان، كما خرج رجلان من أصحاب الإمام

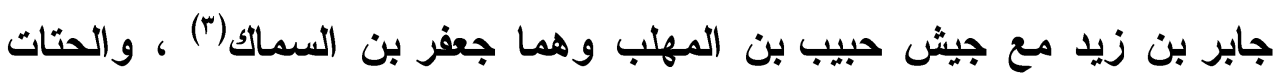

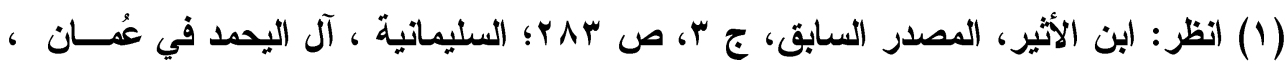

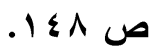

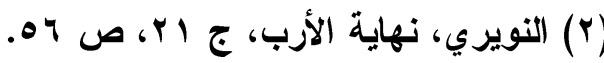

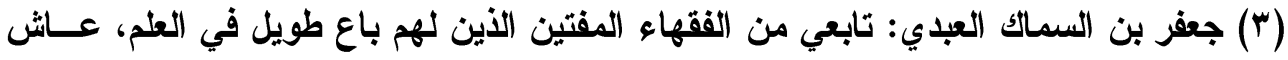

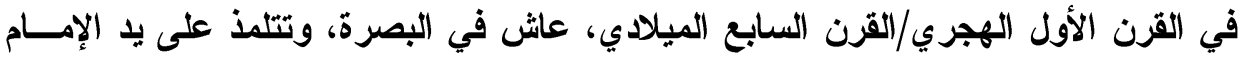

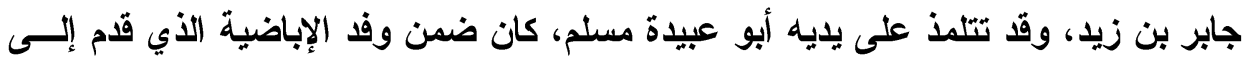

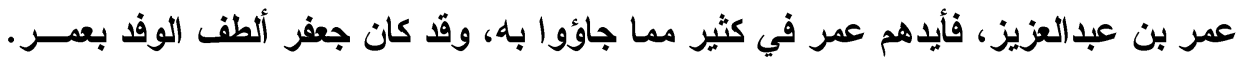

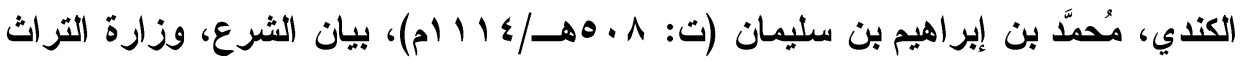

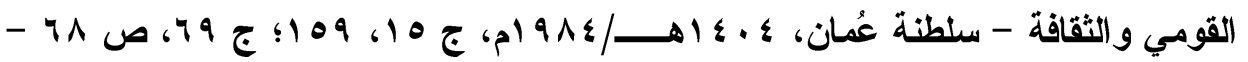

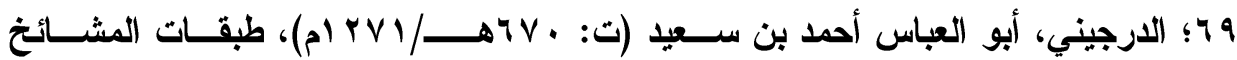

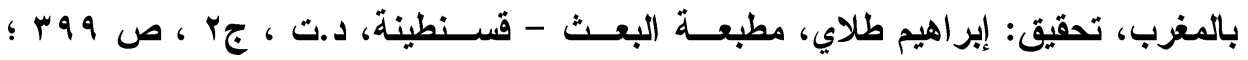

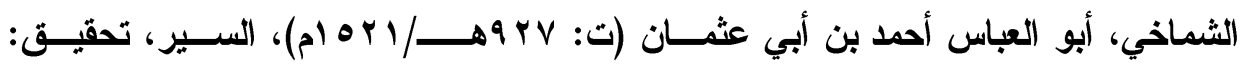

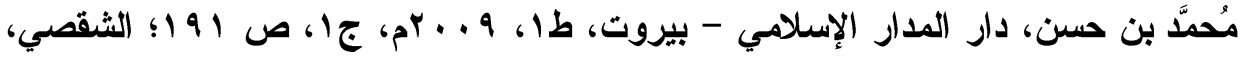

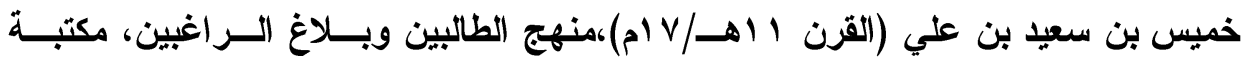

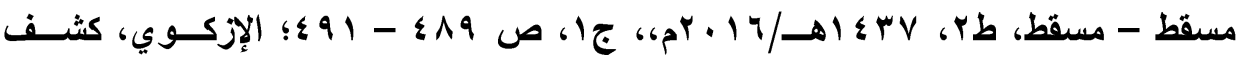

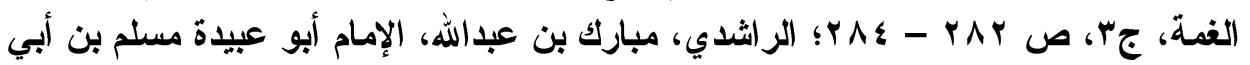

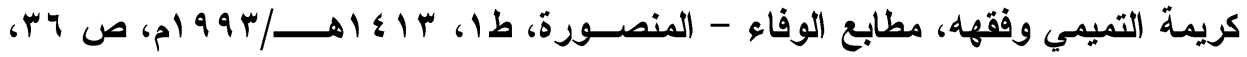

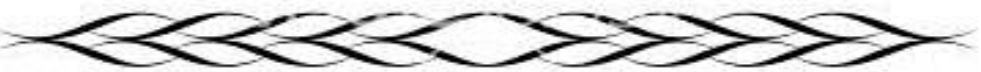


بن الكاتب(1).

ولم تذكر المصادر التاريخية متى أصبحت الإباضية العقيدة المنتشــرة فــي

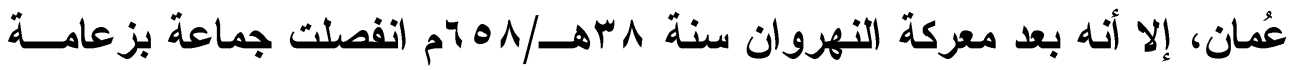
أبي بلال مرداس بن حدير التميمي(؟)، فقضلت السلم وعــدم اللجــوء لاســتخدام السيف لفرض آرائها متخذة من مدينة البصرة مقر الها، وأصبحت هذه الجماعـة

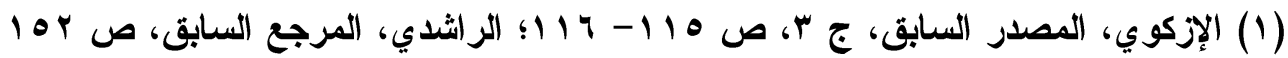

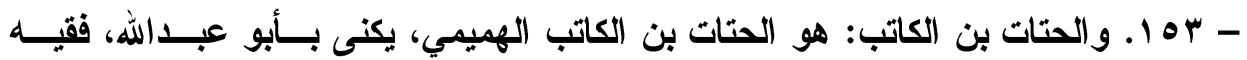

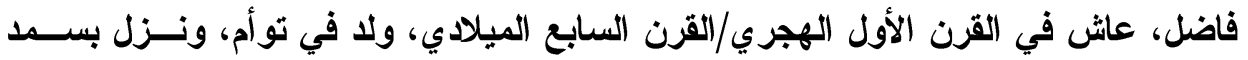
نزوى واستوطنها، وخرج من عمان إلى البصرة لطلب العلم، خرج هو وجعفر بن الســـاك

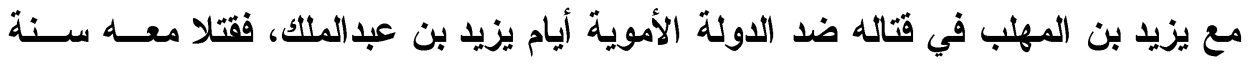

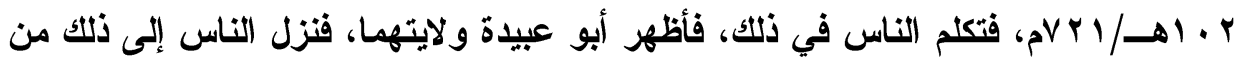

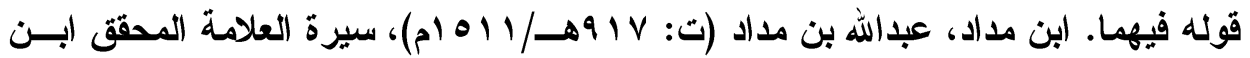

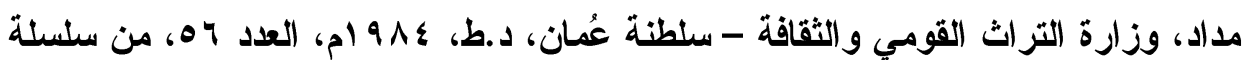

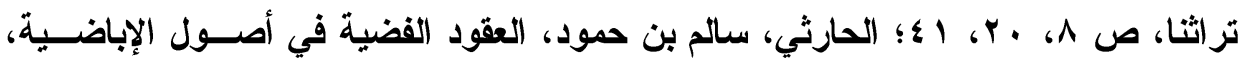

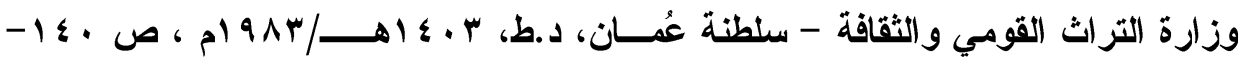
إ ا؛ الراشدي، المرجع السابق، ص ro 1؛؛ الفارسي، ناصر بن منصور بن ناصر، نزوى

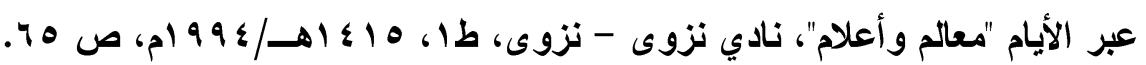

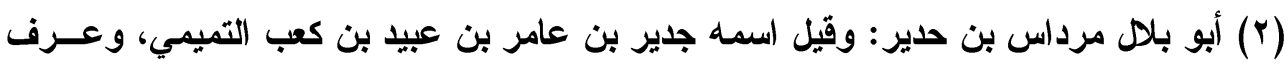

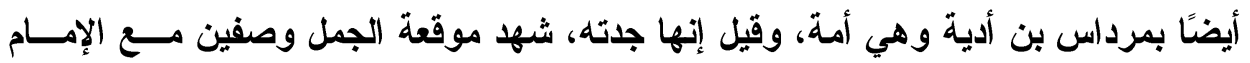

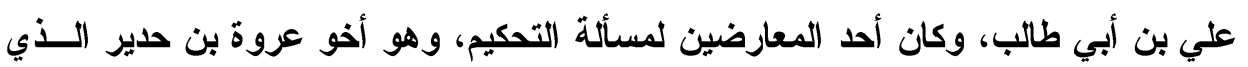

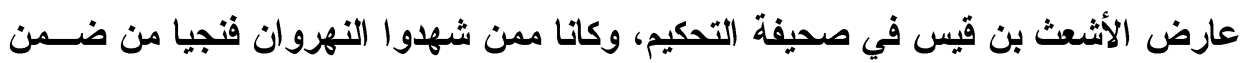

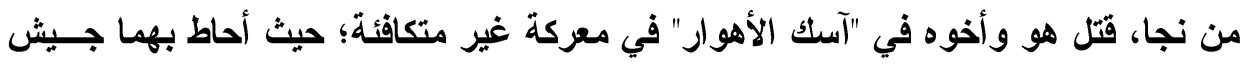

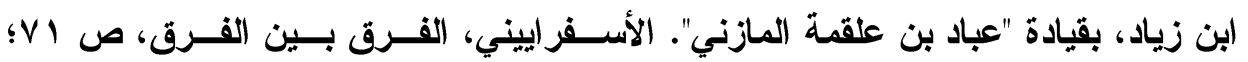

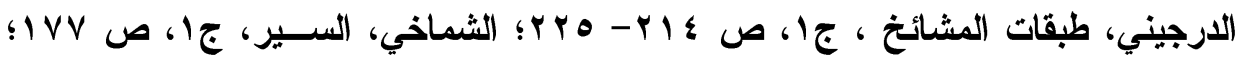

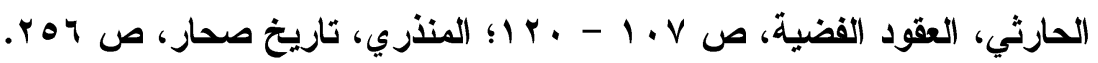

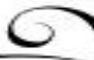


فيما بعد الأسـاس الأي قامت عليه فرقة الإباضية(')، "فقام أبو بلال بنشر دعوتــه و أفكاره فيها، فأنكروا قتل المخالفين واستعر اض الناس علــى طريقـــة متطرفــي الخوارج، وحرموا خروج النساء، ودعا أبو بلال أتباعه إلا يجــردوا ســلاحا ولا يقاتلوا أحدا إلا إذا تعرضوا لعدوان وأجبروا على القتال"(ז)، "ووجدت هذه الأفكار التي كان أبو بلال ينادي بها آذانا صاغية، فانضم إليه الكثير من الناس، وكانـــ هي أساس الافتراق عن منهج الغلاة والمتثددين من المحكمة الذين اعتبروا دار المخالفين دار شرك وأقروا مبدأ قتل كل المخالفين حتى الأطفال والنساء، ووجوب الخروج والهجرة من بلاد المسلمين المخالفين لهم، وقد تزعم الفريـق المتثــدد نافع بن الأزرق()، أما الفريق المعتدل الأي آثر القعود عن قتال أهل التوحيد فقد

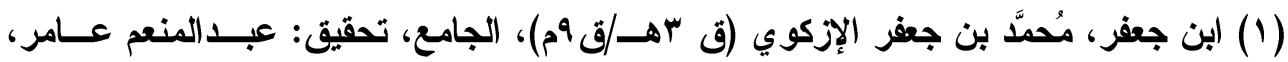

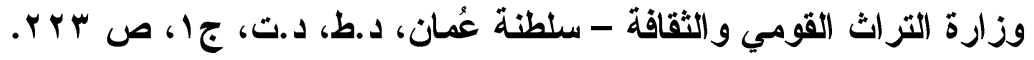

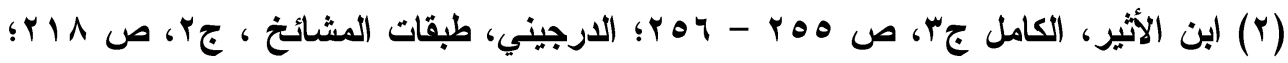

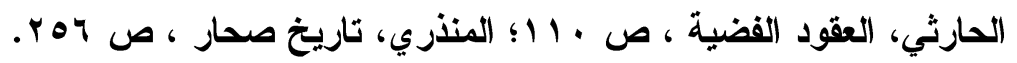

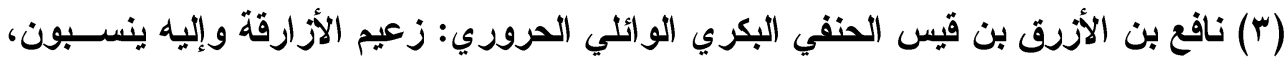
وكان أمير قومهه وفقيههم من أهل البصرة، صحب في بلاية أمره عبدالله بن عبـاس، ولــهـ

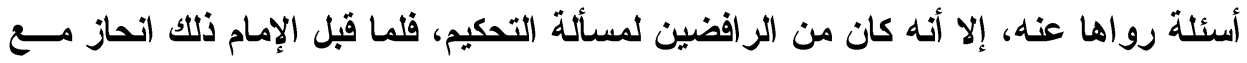

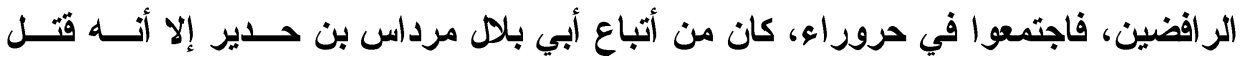

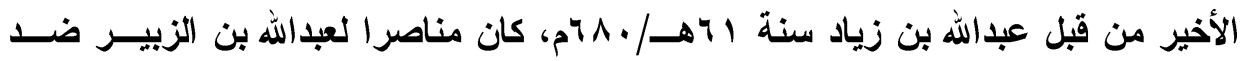

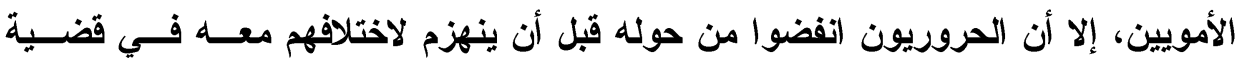

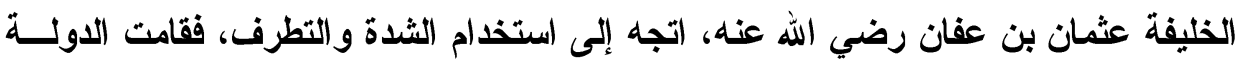

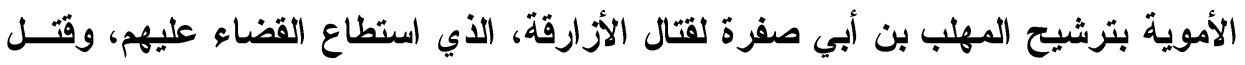

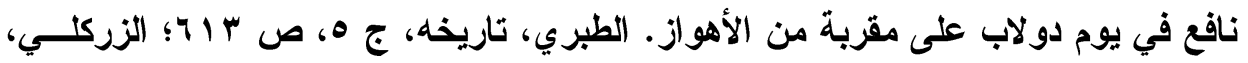

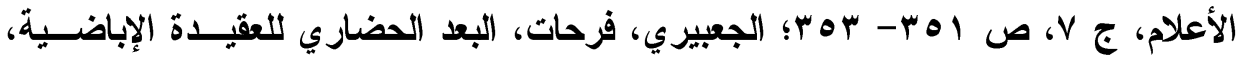

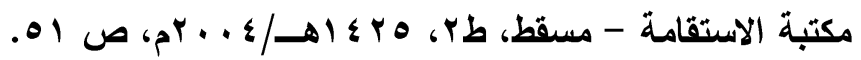

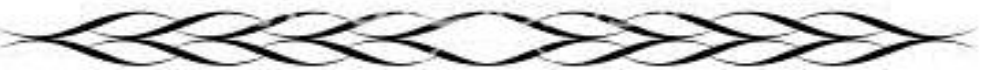




\section{الترقير الدولخ ISSN 2356-9050}

تز تممة ظاهريا عبدالله بن إباض(')، إلا أنه كان ينطلق من راي الإمام جـابر بـن

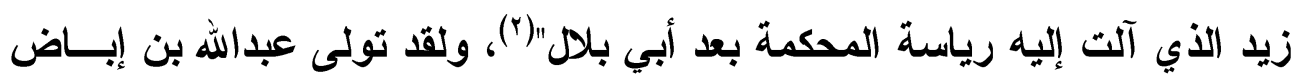

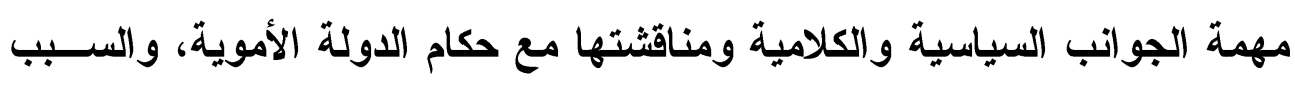

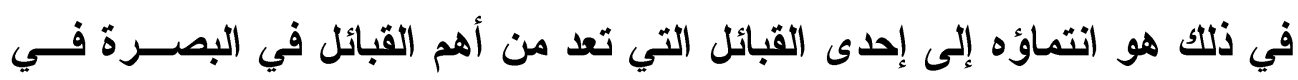

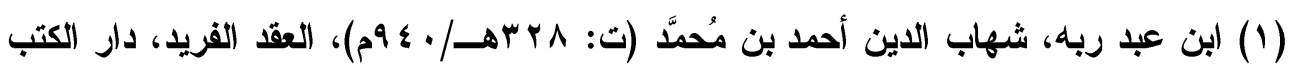

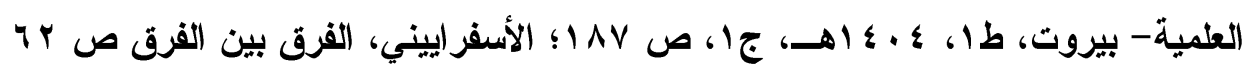

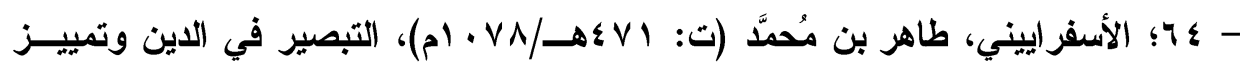

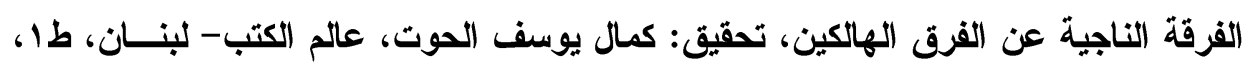

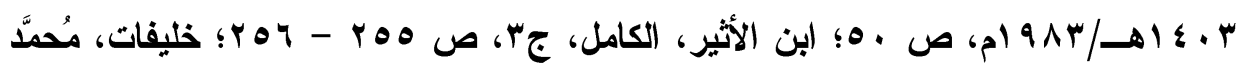

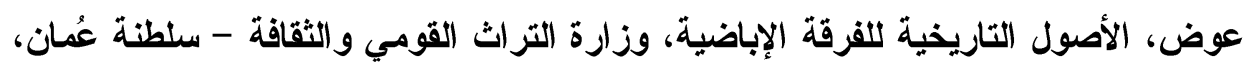

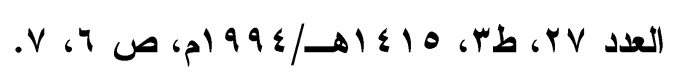

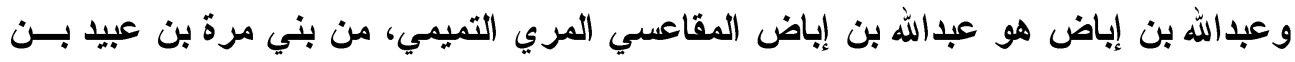

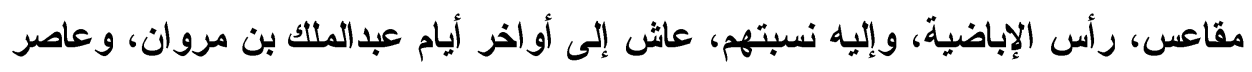

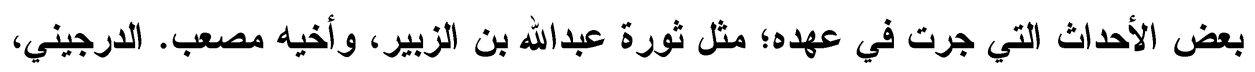

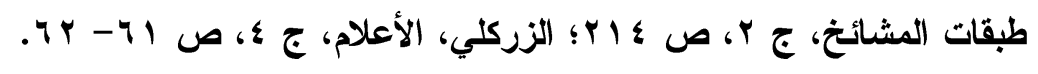

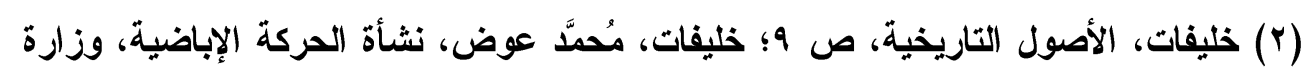

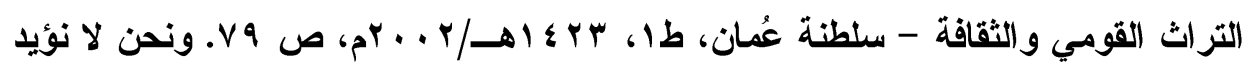

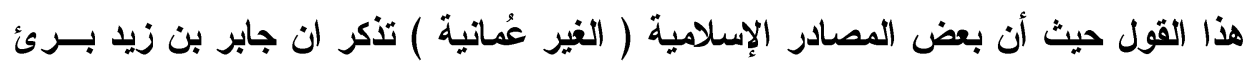

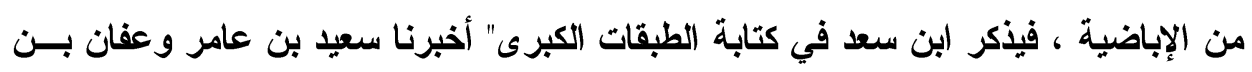

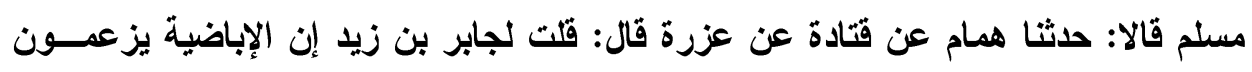

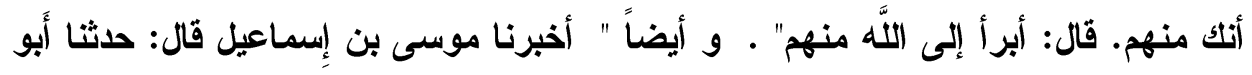

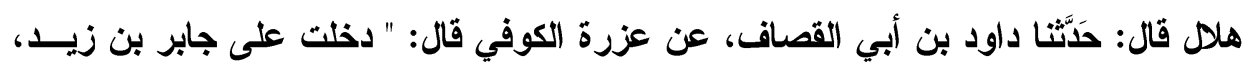

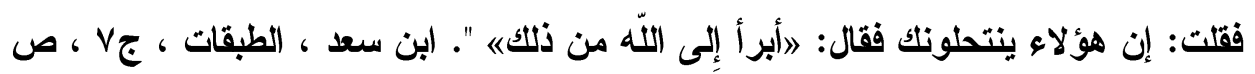

\section{0}


صدر الإسـلام ألا وهي قبيلة بني تميم؛ حيث كاتت سنده القوي(')، ولقـــ ســـي المذهب الإباضي باسمه، رغم أن الإباضية أنفسهم لم يقروا هذه التسمية إلا فــي القرن الثالث الهجري/القرن التاسع الميلادي؛ حيث لم يجدوا حرجا(؟) من التسمي

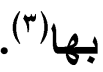

ولقد انتشر الفكر القرامطي أيضًا في عُمان؛ حيث تذكر بعـض المصــادر

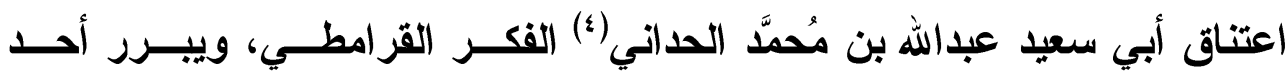
المؤرخين موقفه بأنه كان ربما تقية من أعدائه ليبعد عُمان والإمامة عن أعمالهم العدوانية التي طالت مناطق عديدة من شرقي الجزيرة العربية وجنــوبي غربــي العراق، وأيضًا لكسبهم إلى جانبه ضد أعداء الإمامة في الاخل والخارج(ه).

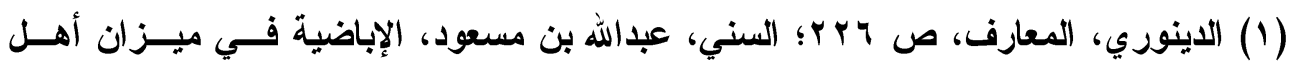

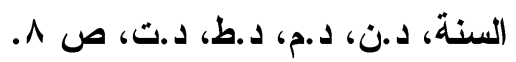

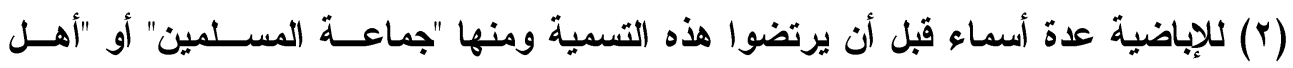

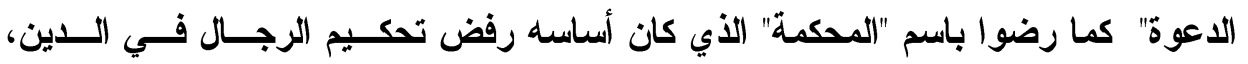

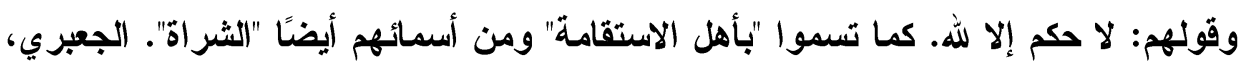

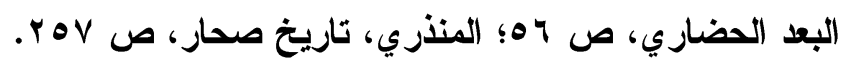

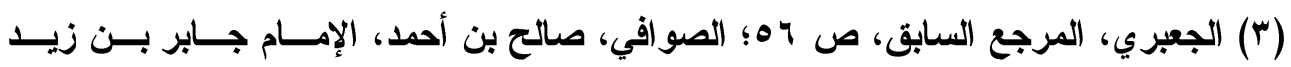

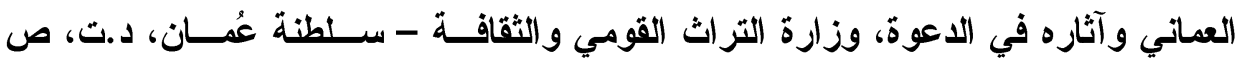

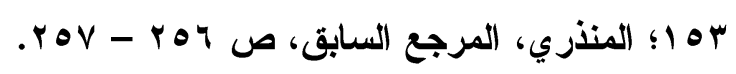

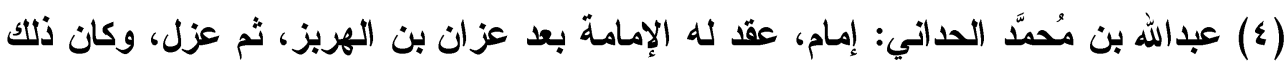

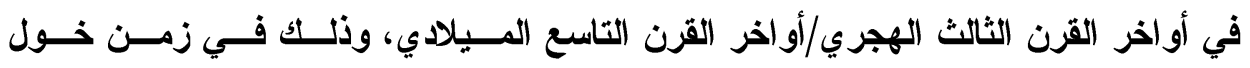

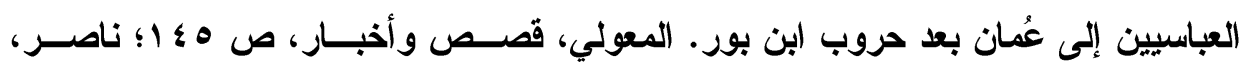

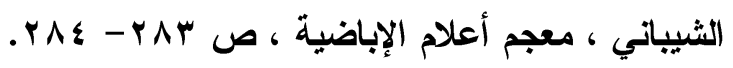

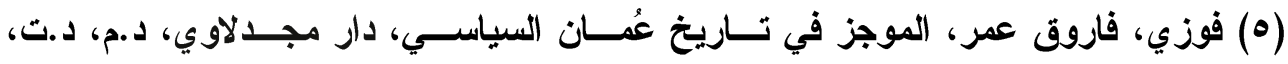

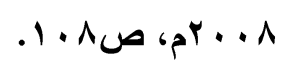

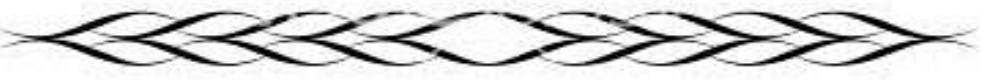


الترقير الدولإ ISSN 2356-9050

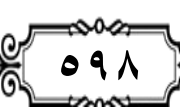

091
حولية كلية اللفة العربية بجرجا مجلة علمية محكمة

وقد لاقى موقفه معارضة من قبل علماء الإباضية خسر بسببها منصــبه، فأصدر الفقيه أبو الحواري حكمًا بالبراعة منه، وعلى أثره عزل من الإمامة: "تحن هون نبرأ من أبي سعيد، ونبرأ ممن تولاه، ونبرأ ممن وقف عنه، ونبرأ ممن شك فيه من بعد رجوعه من السوق إلى نزوى (1)، هذا وأما عقد إمامته فلا نقــول فيهـــا شيئًا، وأما من بعد خروجه من نزوى ورجوعه إليها من بعد دخوله في القرامطة فنحن نبرأ منه بعد ذلك إلى هذا اليوم"(؟)، وقد شدد العلماء عليه لارجة أن قالوا: "ولا ينبغي لعاقل أن يناظر في أبي سعيد ولا في عقد إمامته"()، قال: "وإنما كــان

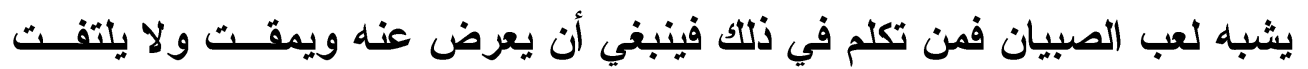
إليه"( (๕)

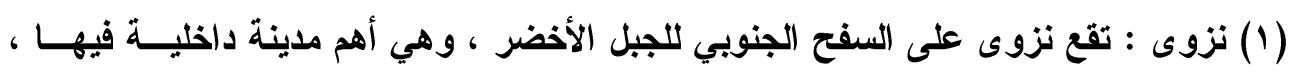

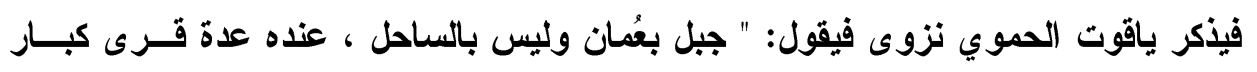

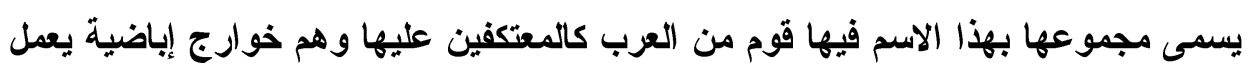

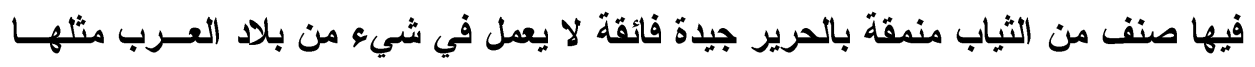

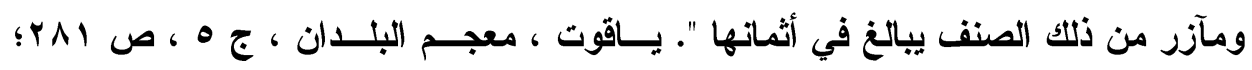

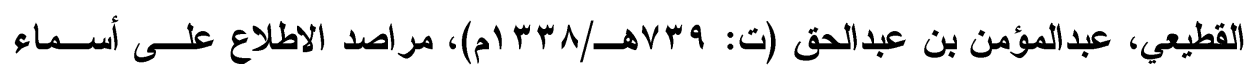

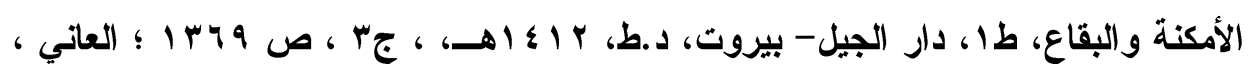

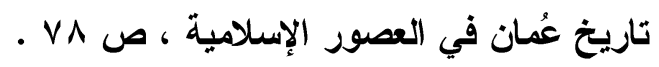

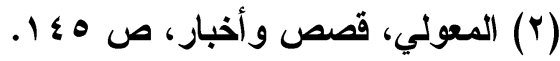

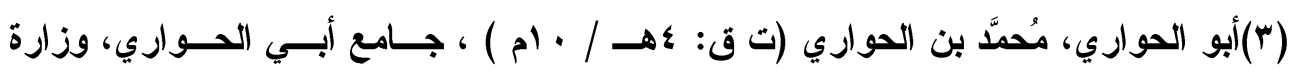

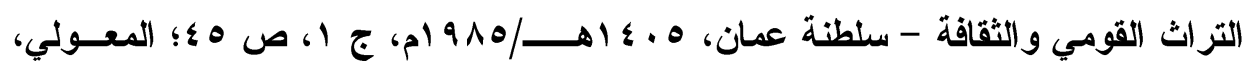

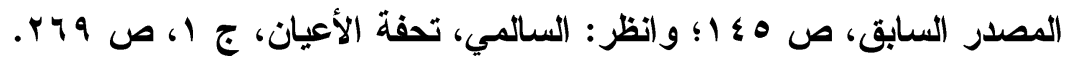

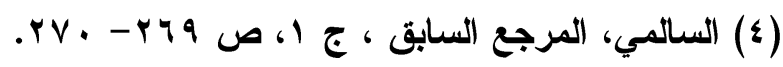


وأدى بعض العلماء دورًا كبيرًا في محاولة قمع فتنة القرامطة والحد مـن

انتشارها في المجتمع، فقد أطلق العالم أبو المؤثر الصلت بن خميس الخروصي(') الحكم بحقهم إذ دعا بحرق بيوتهم (ץ)؛ وذلك لأنه "لا بـ للقوم من مخاصم أحرقــوه لئلا يرجعوا إليها"()، وحجته في ذلتك أنهم "أحرقوا منازل الناس وســـاروا فـيهم بسيرة أهل الشرك؛ لأن أهل الشرك يجوز تخريب منازلهم وقطع نخلهم وشجرهم ما دامت الحرب قائمة فإذا انهزموا لم يحل شيء مــن ذلــك وصــارت أمــوالهم غنيمة" (๕) ولقد استنكر المسلمون كافة ما قام بـه أبو المؤثر من الحـــرق وقــالوا: إن كان القوم بغاة وأحرقوا فعليهم غرم ما أحرقوا، وإن كانوا مشــركين وأمــوالهم غنيمة، فلم تُحرق بيوت المسلمين؟ إلا أن أبا المؤثر أعرض عنهم غاضبًا وبـين موقفه للمسلمين أنه لا بد من مخاصم لهؤلاء القوم فتحرق بيوتهم كي لا يرجعوا يسكنونها، والمسلمون لا يعرفون بالتحديد من اعتدى من القرامطة على حرمسـات

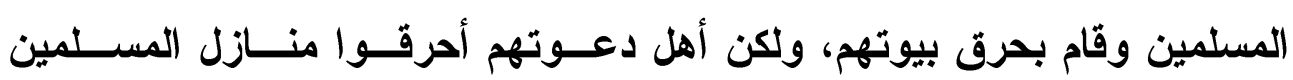
واستحلوا أموال الناس ودماءهم، واستحقوا بذلك الحكم بحرق بيوتهم(ه).

(1) الصلت بن خميس الخروصي: عالم، فقيه، عاث في القرن الثالث الهجري/القرن التاســـع

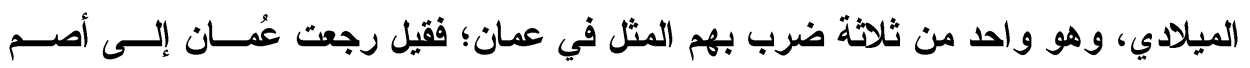

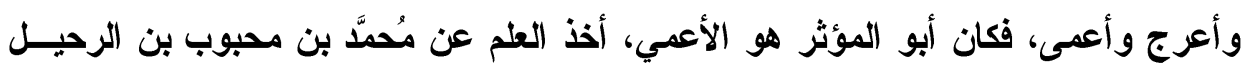

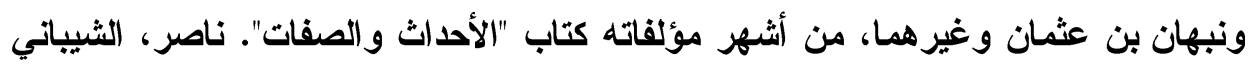

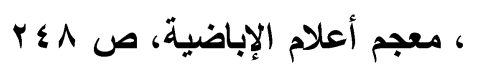

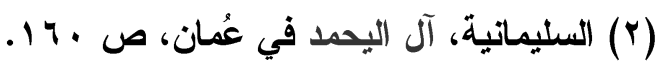

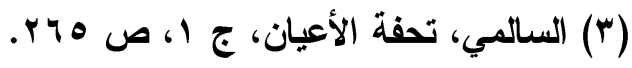

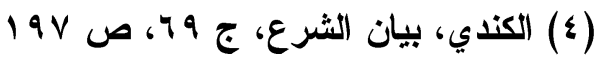

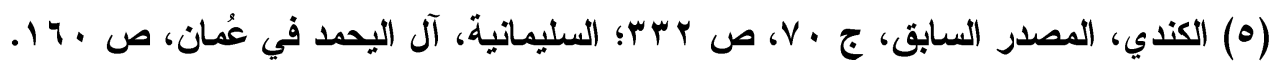




\section{الترقير الدولخ}

ISSN 2356-9050

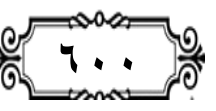

ويشبه العلماء هذا الحكم بحم النبي صلى الله عليه وسلم حين حكم بحرق

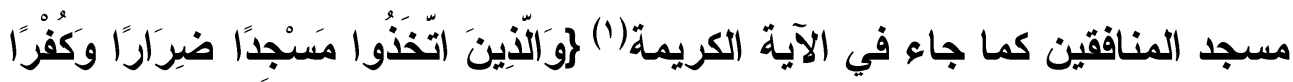

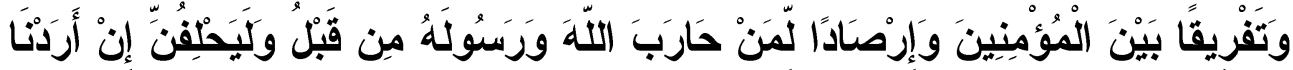

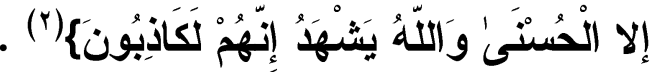
ولقد ظهرت من الناحية الفكرية بعض المسائل الفقهية الجديدة في أحكـام المعاملات المرتبطة بالفرقة القرمطية، والتي حكم فيها العلماء بالقياس ميع أحكام

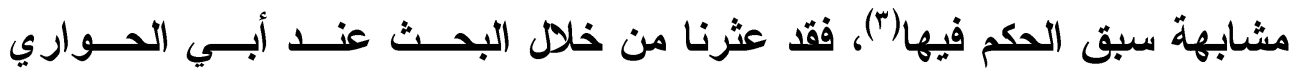

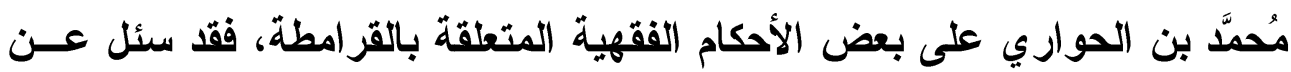

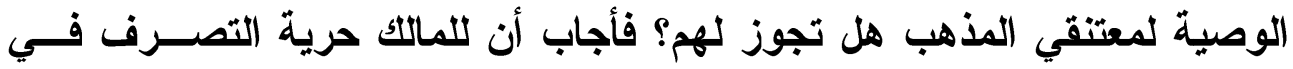

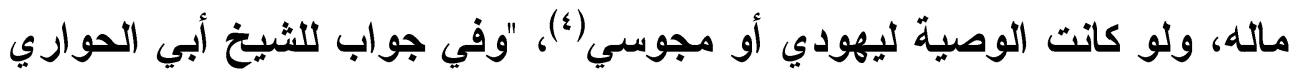

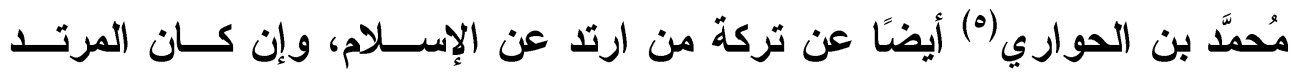

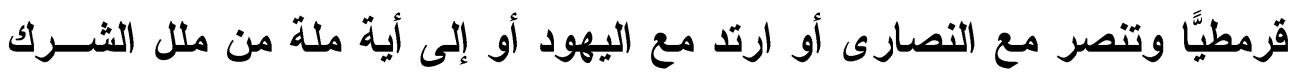

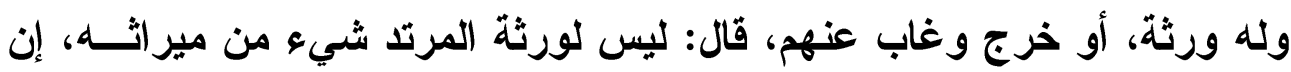

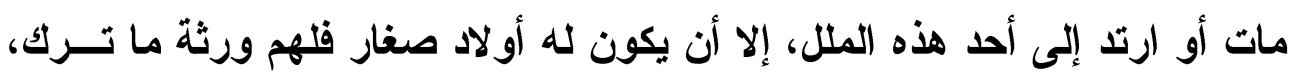

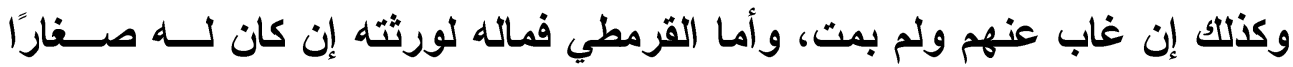

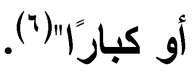

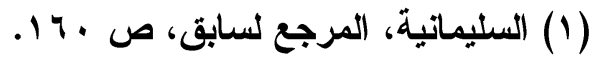

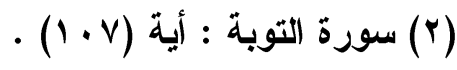

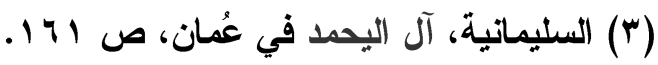

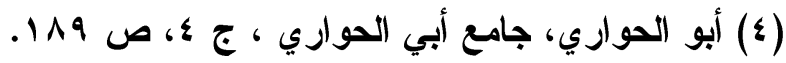

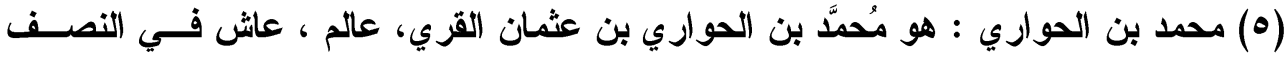

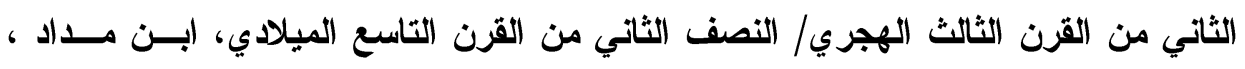

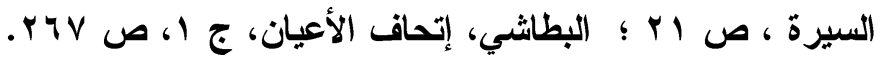

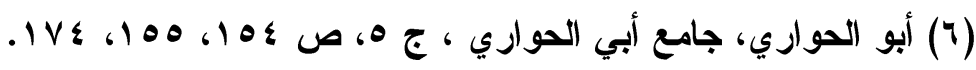

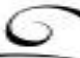


كما عثرنا على مسألة تختص برجل له شراكة في مال لغائب في البحرين من القرامطة فأراد الرجل تقسيم الثراكة، وأقام المسلمون وكيلاً يشهر سهمه هـه بحضور العدول وأعطوا الغائب أحسن السهام وفيها زيادة، فكان جوابه الجواز في

ذلك (')

ومن خلال ما سبق يمكننا أن نستنتج أن العلماء كانوا شديدي الحرص على قلع جذور الفتنة، وذلك خثية من اعتناق المزيد من العُمانيين لأفكار المذهب اقتلاء بمن سبقهم من إخوانهم.

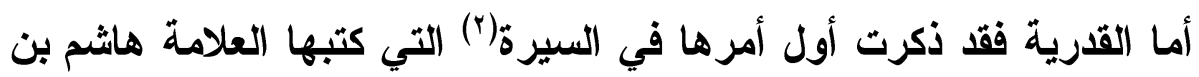

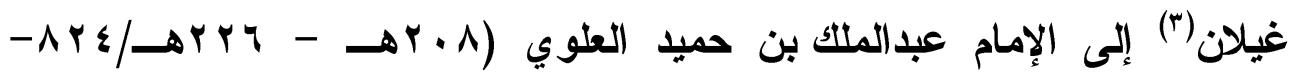

$$
\text { (1) أبو الحواري، المصدر السابق، ج ه، ص } 10 \text { (1) }
$$

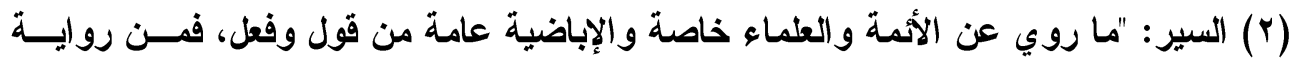

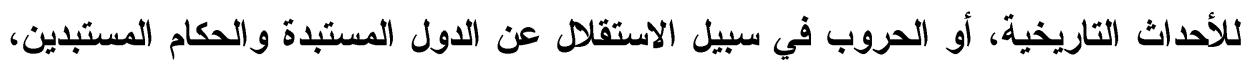

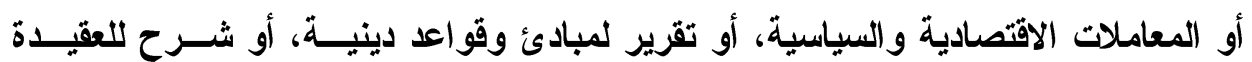

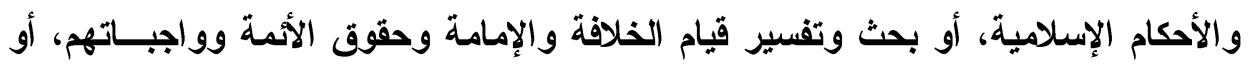

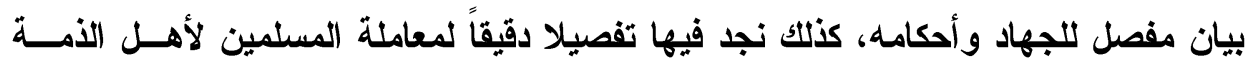
و المشركين، إلى غير ذلك مما يسجل تاريخ شعب أولا بأول". مجهول ، السير و الجوابـات ولهات

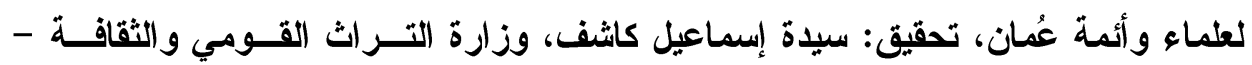

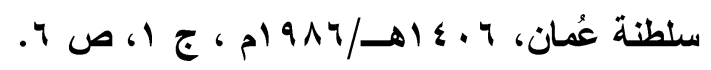

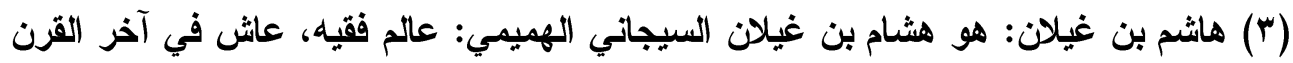

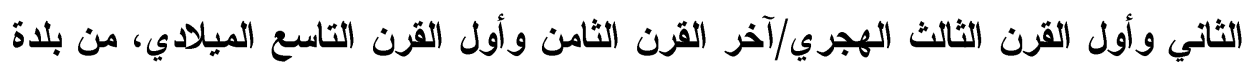

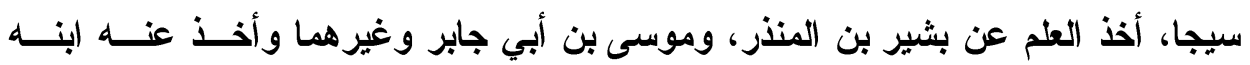

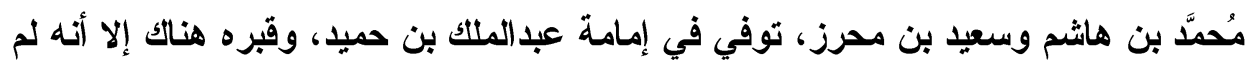

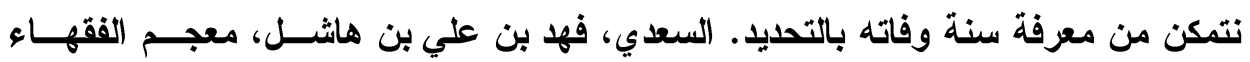

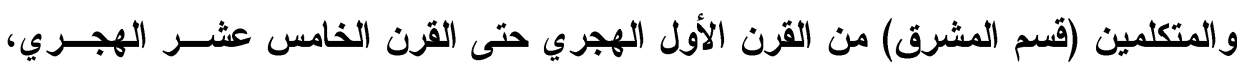

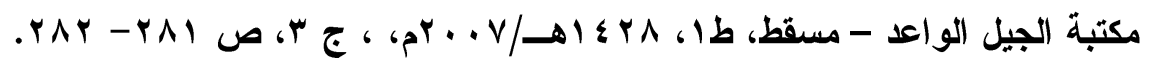




\section{الترقير الدول\$ \\ ISSN 2356-9050}

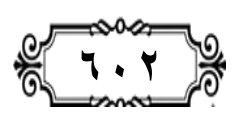

اءیم)(') حيث جاء فيها: "وأن بلغنا أن قومًا من القدرية.. بصحار قد أظهرو دينهم ودعوا (لناس إليه، وقد كثر المستجيبون لهم، ثم صاروا بتوم(؟) وغيرها

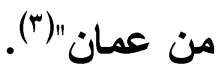

وكان أول أمر ظهورها في صحار، ومنها انتقلت إلى تؤام، ومنها إلى بقية المناطق، وحين تسربت أفكارهم بين أهل عُمان اعتنقها البعض منهم، لكن العلماء كانت لهم ردة فعل حيث وقفوا موقفًا حازمًا ضدها، فقد أثشار العلامة هاشم في أنمان

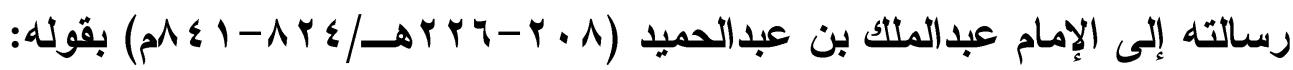
"وقا يحق عليك أن تنكر ذلك عليهم، فإنا نخاف أن يعلو أمرهم في سلطان المسلمين فاؤمر يزيد واكتب إليه ألا يترك أهل البدع على إظهار دعوتهم حتى لهم يطقى الظلال والبدع"(๕). وفي ذلك الوقت كتب الثيخ أبو المؤثر الصلت بن خميس عن فرقة القدرية سيرة له، موضحًا للناس حقيقة عقيدتهم، فقال: "ومن ذلك أيضًا ما أحلثت القدرية، من قولهم إن لله تبارك وتعالى لم يخلق الحركات ولا السكون من الحيوان وإنه لم يخلق شيئًا من أفعال العباد"(ه) وبالفعل وقف الإمام موقفًا صارمًا ضد أصحاب هذه الفرقة؛ إذ أرسل إليهم ياعوهم إلى العودة إلى حظيرة الاين

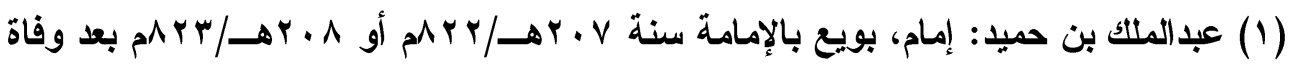

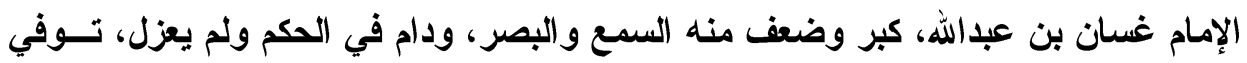

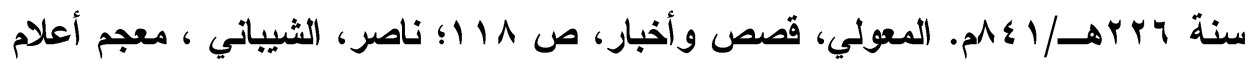

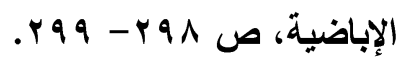

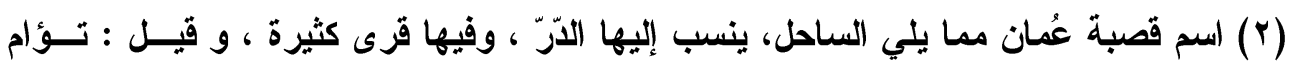

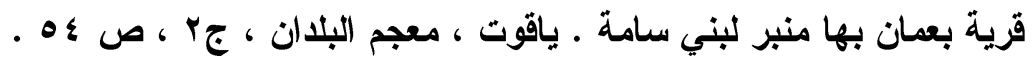

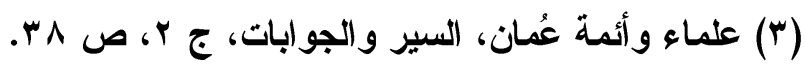

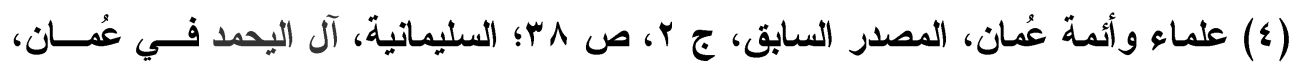
ص ص

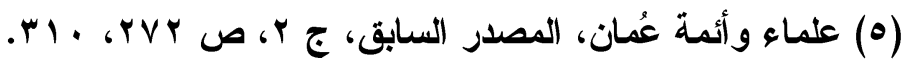


القويم، واصفا لهم حقيقة الدين ومثبتا القدر، فمن قبل كلامه عفى عنه وأطلق سراحه ومن أصر على قوله وجب حبسه ومعاقبته('). وللمسلمين منهج يتبعونه ويطبقونه مع الفئات من غير المسلمين الذين يعيشون تحت ظل الدولة الإسلامية، فقد وضح هاشم بن غيلان ذلك في سيرته حين قال: "وكانوا رحمة لله عليهم إذا بلغهم من أحد أنه على غير دين المسلمين أرسلوا إليه وعرضوا عليه دينهم، فإن قبله كان له ما لهم وعليه ما عليهم، وإن أبى إلا أن يظهر غير ما عليه دين الإسلام أمروه بالخروج من بلادهم، فإن خرج تركوه، وإن لم يتب ولم يخرج لم يقروه على ذلك، وأكرهوه على قبول

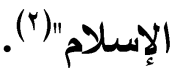
ولقد سعت جماعة القدرية لإشثاء مدارس خاصة بهم في صحار لنشر دعوتهم خلال إمامة عبدالملك بن حميد لكنها باعت بالفشل الذريع؛ وذلك بسبب جهود الأئمة والعلماء العُماتيين(ّ). وقام العلماء في ذلك الوقت بإصدار بعض الأحكام المتعلقة بالقدرية، وما يجب التعامل به معهم؛ منها ما ذكره أبو الحسن البسيوي(؛) في سيرته، ذاكرًا عقيدتهم والأحكام المترتبة على من اعتنق دينهم(•): "فإن رجع إلى دين القدرية وقال "لا قر" وادعى القدرة والمشيئة والإرادة إليه.." قال: "في كل هذه تلزمه

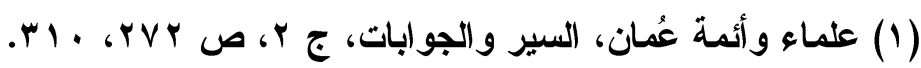

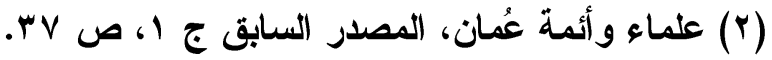

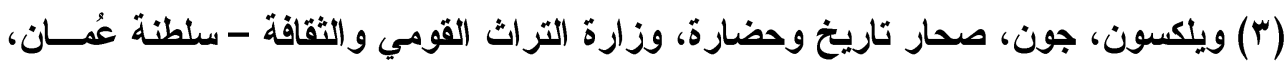

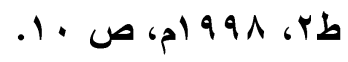

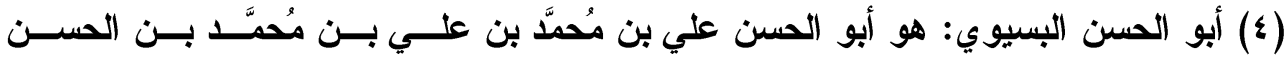

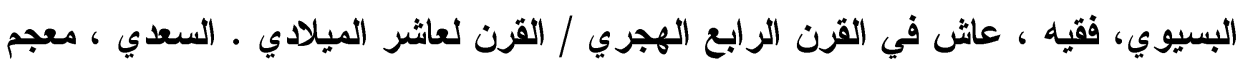

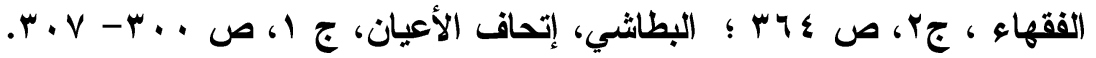

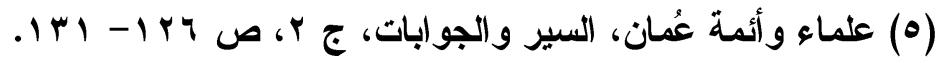




\section{الترقير الدولخ}

ISSN 2356-9050

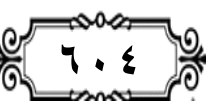

البراعة والمفارقة"(1)، وقوله في مكان آخر : "واستتبه فإن تاب قبل منه، وإن أصر

برئ منه وزالت إمامته وحورب حتى يعزل أو يقتل ويقدم إمام غيره"(؟).

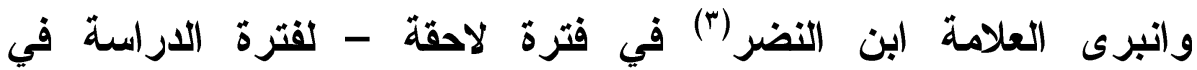
معارضتهم، فألف فيهم قصيدة، جاء فيها:

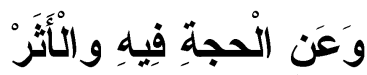

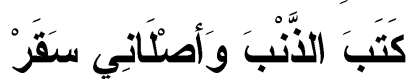

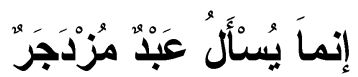

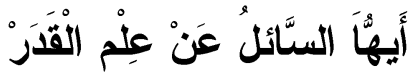

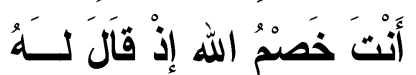

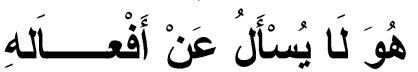

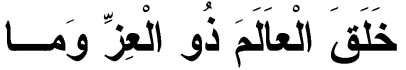

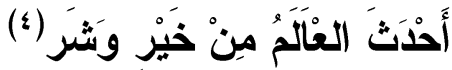

أما المرجئة فقد ظهرت أول أمرها في صحار، ومنها انتقلت إلى بقية

المناطق، وفي ذكرها يقول العلامة هاشم بن غيلان للإمام عبدالملك (1 •rهـــ

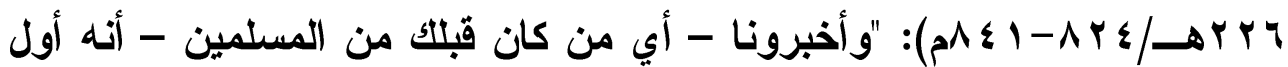
شيء ساروا به في الناس أن علموهم دينهم... ومن كان على غير دين المسلمين من أصناف الخوارج والثكاك.... ذم يلعوهم على ذلك حتى دخل الناس في الإسلام... وأنه بلفنا أن قومًا من أهل المرجئة بصحار قد أظهروا دينهم ودعوا الناس إليهم، وقد كثر المستجيب لهم، ثم صاروا بتوام وغيره، وقد يحق للك أن

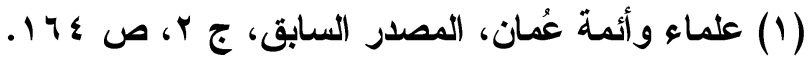

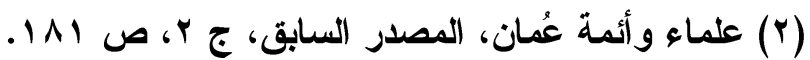

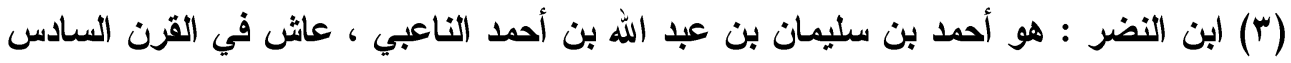

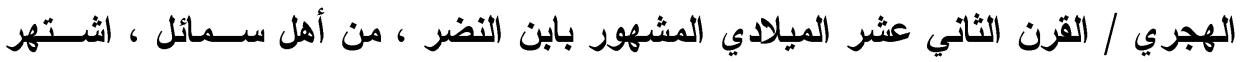

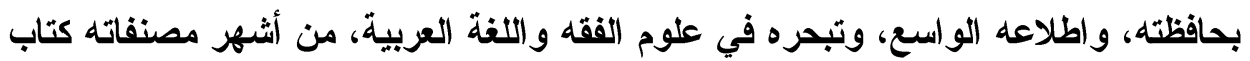

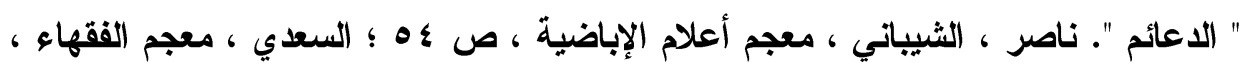

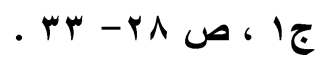

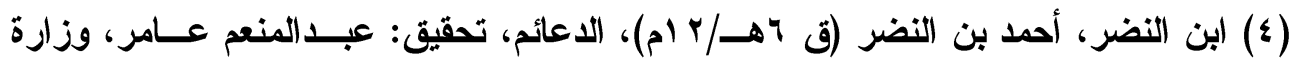

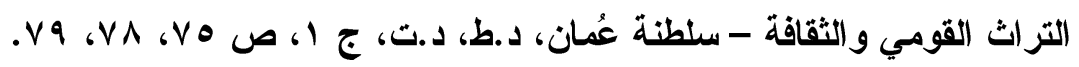


تنكر ذلك عليهم، فإنا نخاف أن يعلو أمرهم في سلطان المسلمين"(1). ونستدل مما سبق على أن فكر القدرية والمرجئة انتشر وأصبح سمة بارزة، حتى إنه لفت انتباه العلماء في عُمان، فوقفت منه موقفا صارمًا، ولقد انعكس ذلك على المصنفات العُمانية التي تناولت أفكار المرجئة والقدرية بالعرض و المناقشة؛ حيث ناقشها العلامة ابن بركة(؟) في كتابه "الموازنة"، والعلامة أبو

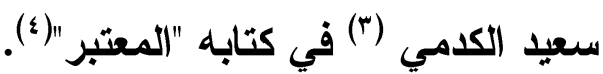
ومع ظهور الكثير من المذاهب و الافكار في عُمان ألا أن المذهب الســي ماز ال منتشراً في عُمان ففي نهاية القرن الثالث والنصف الأول من القرن الرابع الهجري/نهايه القرن التاســع المــيلادي والنصــف الأول مــن القـــن العاثــر الميلادي،وذلك بسبب تبعيتها للخلافة العباسية، فقد تولى السلطة فيها ولاة مسن قبل الخلافة، أولهم أحمد بن هلال(ه)، ثم أسرة آل وجيه التي كانت السلطة فيهـا

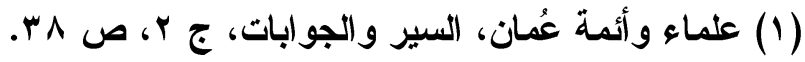

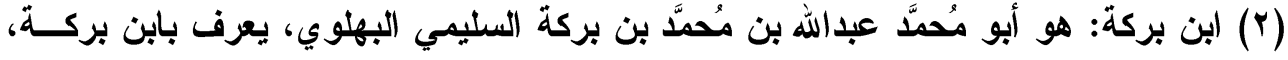

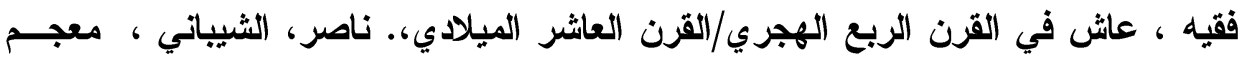

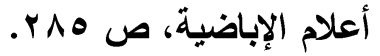

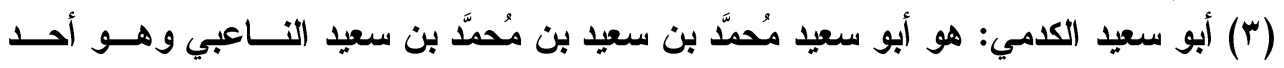

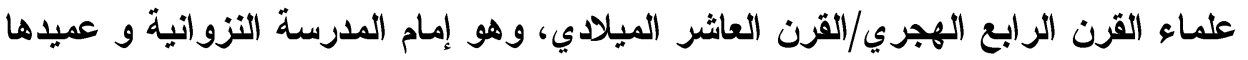

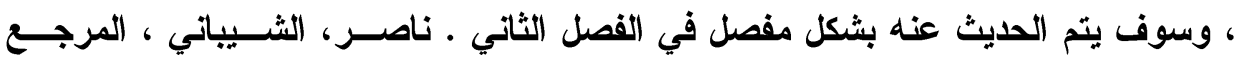

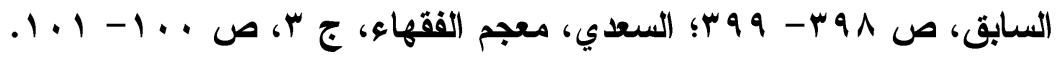

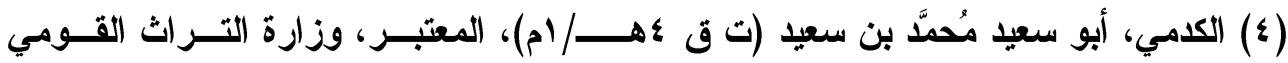

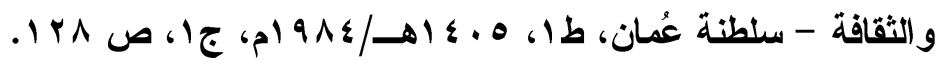

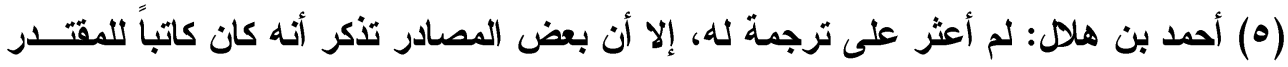

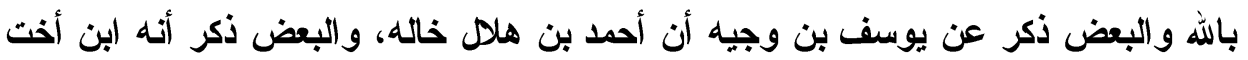

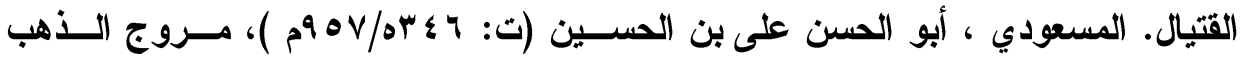

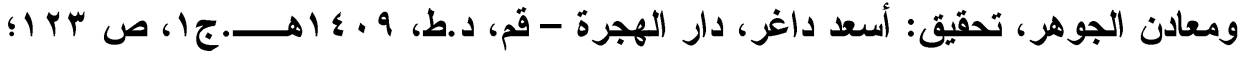

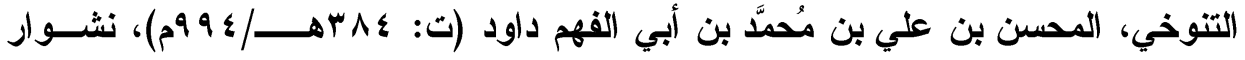

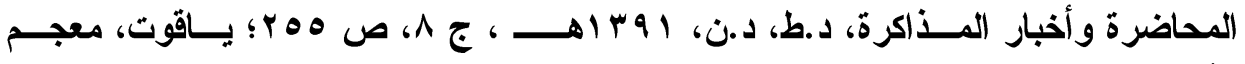

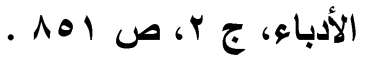




\section{الترقير الدولخ \\ ISSN 2356-9050}

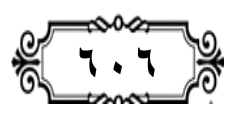

وراثية حتى منتصف العقد السـادس من القرن الرابـــع الهجري/منتصــف القــــن

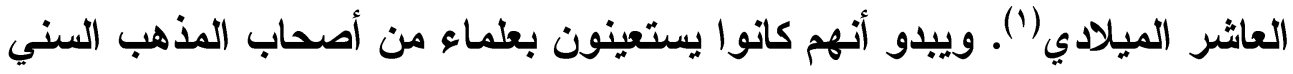

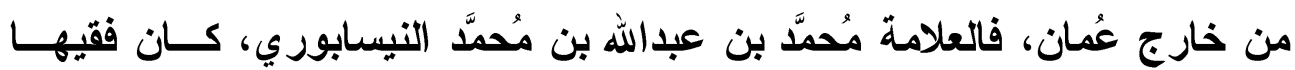

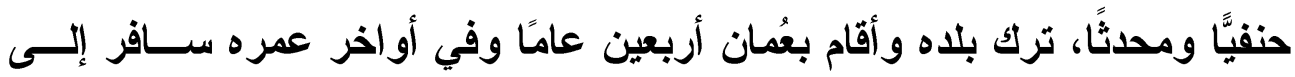

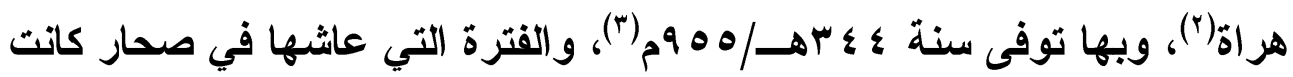
تحت سلطة الخلافة العباسية وولاتها الأين تقدم ذكرهم، وعذدما تغلب البويهيون على صحار وكانوا على المذهب الثيعي تولت لهم أسرة بني مكرم السلطة فــي

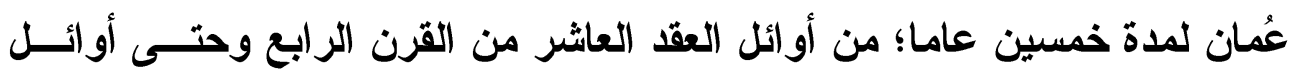

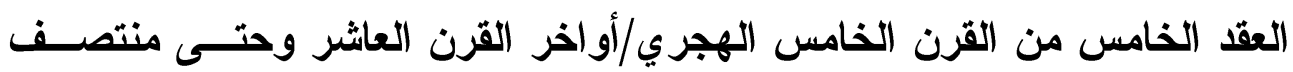

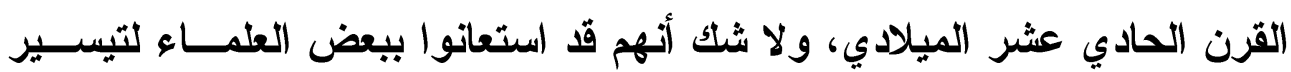
أمور حكمهم، ولقد عرفت عمان المذهب الثيعي قبل ذلك التاريخ بزمن طويل(؛)؛ كما كان للمعتزلة ذكر في صحار (•).

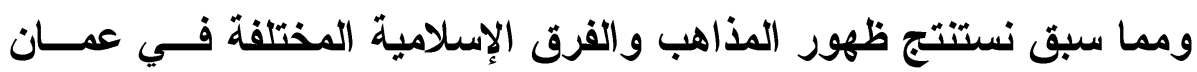
كالمذهب السني والثيعي والقرامطي وغيرها بالإضافة إلى المذهب الإباضي الذي عرفه العُمانيون قبل غيره من المذاهب فشكل ركيزة المجتمع.

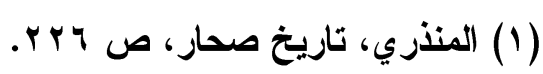

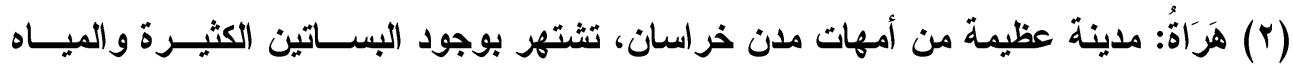

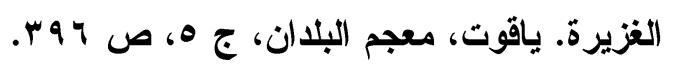

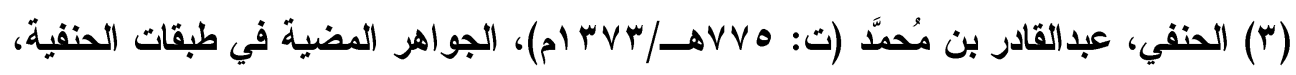

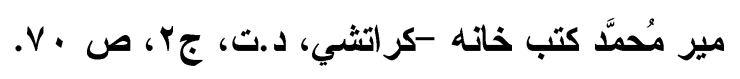

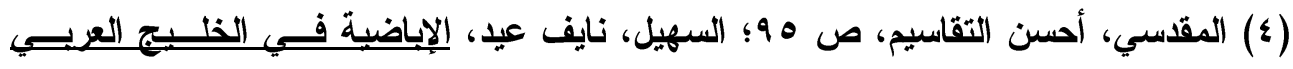

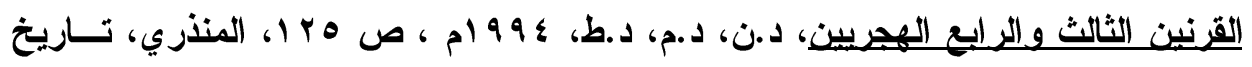

صحار، ص צ47.

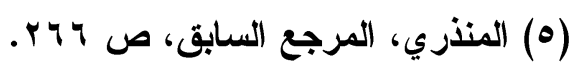




\section{الخاتمة :}

لقد تمتعت عُمان بموقع استراتجي مميز ، جعلها تحتلك بمن حولهــا مــن المدن سواء كان ذلتك لاهداف تجارية او علمية او دينيه أو غيرها، فانتشرت في عُمان كما مر بنا العديد من الفرق و المذاهب الإسلاميه ، فمن العرض السابق نستنتج ما يلي : n - n

ا- إن أول من أسلم من أهل عُمـان هو الصحابي مازن بن غضوبه رضــى الله

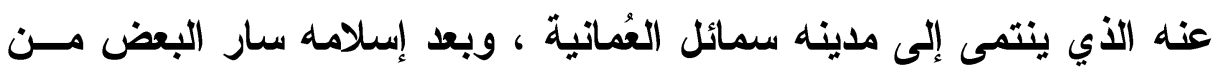

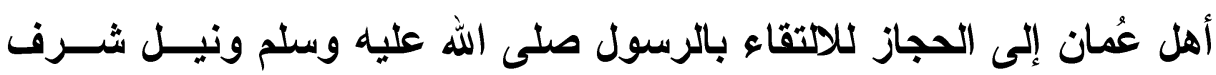
صحبته، والأخذ من معين علمه وإرشاداته، كما تثرف البعض الآخر مــنهم بصحبة صحابته حيث كاتت وفادتهم بعد وفاته صلى الله عليه وسلم.

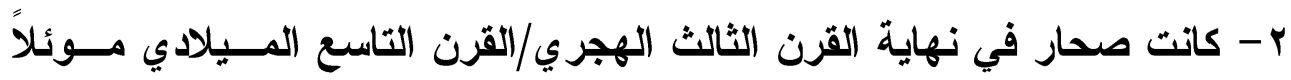

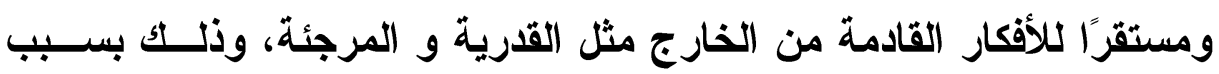
بيقائها مفتوحة الأبواب لمختلف الأجناس من الناس ،

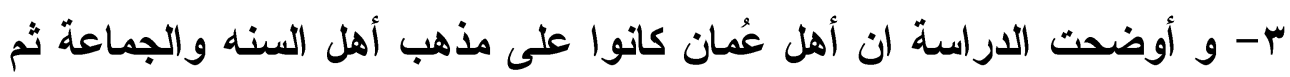
بعد ذلك ظهر المذهب الإباضي والأي ينسب البعض تأسيسه إلى جابر بن زيا

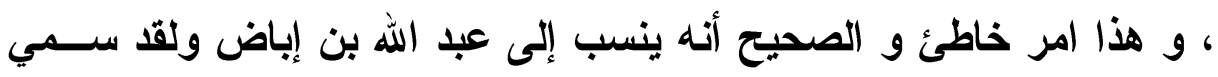
المذهب الإباضي بهذا الاسم نسبة إليه . ع- ولم تذكر المصادر التاريخية متى أصبحت الإباضية العقيدة المنتشــرة فــي

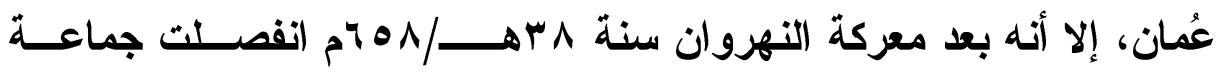
بزعامة أبي بلال مرداس بن حدير التميمي ، ففضلت السلم وعـدم اللجــوء

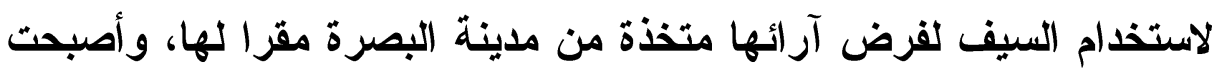
هذه الجماعة فيما بعد الأساس الأي قامت عليه فرقة الإباضية . 


\section{الترقيم الدولخ}

ISSN 2356-9050

ه- وقف علماء الاباضية موقف حازم ضد من يعتنق أي فكر دخيل عليهم مثــل

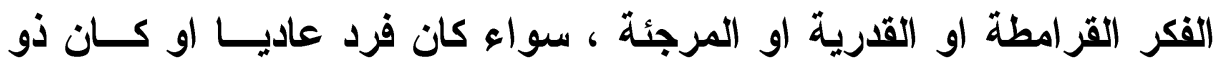
منصب في مجتمعهم ومن ذلك موقفهم الصـــارم مــع الإمــام أبــي ســعيد عبدالله بن مُحمَّد الحداني المذهب القرامطي الأي اعتنق الفكر القرامطي فكان نتجيه اعتناقه ان خسر منصبه . צ- ونستدل مما سبق على أن فكر القدرية والمرجئة انتشر وأصبح سمة بارزة، حتى إنه لفت انتباه العلماء في عُمان، فوققت منه موقفًا صارمًا، ولقد انعكس أنس ذلك على المصنفات العُمانية التي تناولت أفكار المرجئة والقدرية بـالعرض التص و المناقشة؛ حيث ناقشها العلامة ابن بركة في كتابه "الموازنة"، والعلامة أبو سعيد الكدمي في كتابه "المعتبر. V- ومع ظهور العديد من الأفكار و المذاهب في عُمان ، الإ ان المذهب السني ما

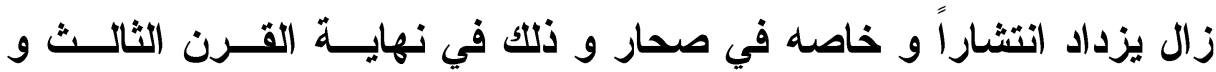
النصف الأول من القرن الرابع الهجري / نهاية القرن التاســع المــيلادي و النصف الأول من القرن العاشر الميلادي ، وذلك بســبـ تبعيتهـــا للخلافــة العباسية، فقد تولى السلطة فيها ولاة من قبل الخلافة؛ أولهم أحمد بن هلال، ثم أسرة آل وجيه، كما عرفت عُمان المذهب الثيعي فعندما تغلب البويهيون على صحار كانوا على المذهب الثيعي وتولت لهم أسرة بني مكرم الســلطة في عُمان لمدة خمسين عامًا. 


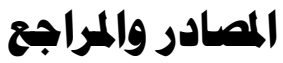

أولاً :المصادر:

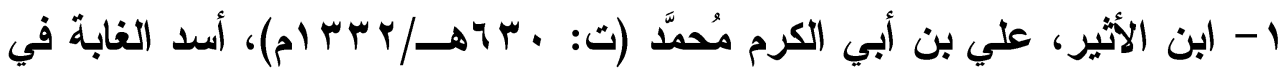

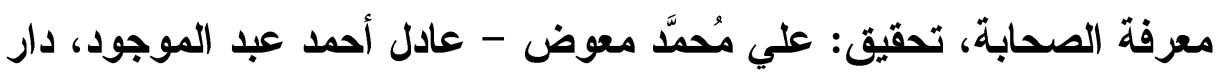

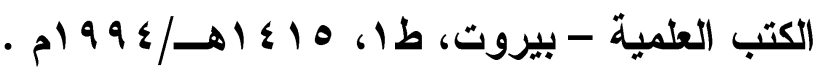

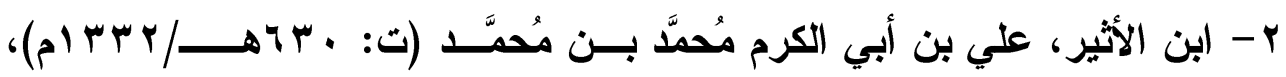

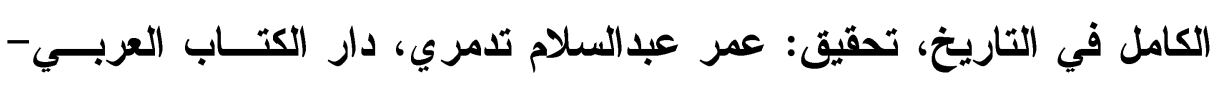

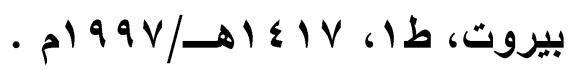

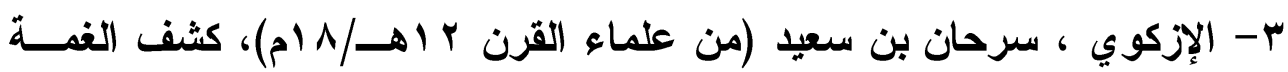

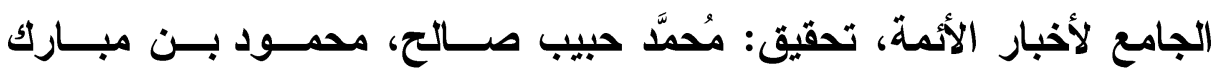

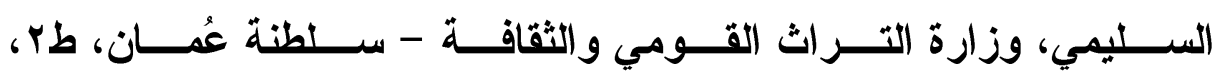

$$
\text { - }
$$

ع- الإزكوي ، سرحان بن سعيد (ق ب أهـ/1 ام)، تاريخ عُمان المقتبس من

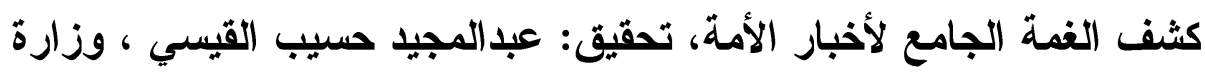

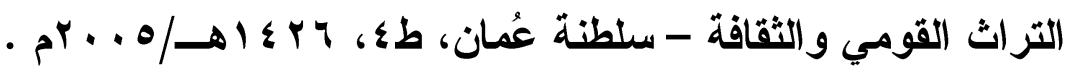

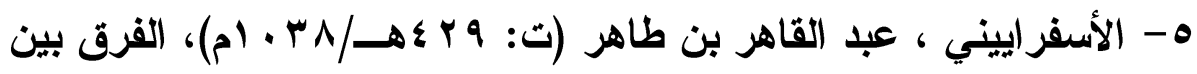
الفرق وبيان الفرقة الناجية، دار الآفاق الجديدة- بيروت، طץ،

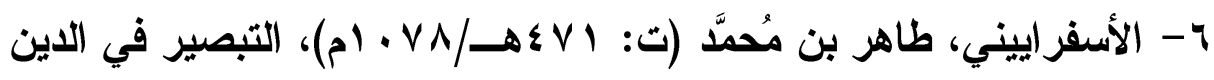

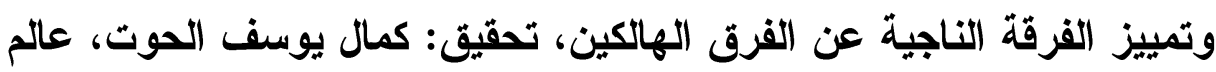

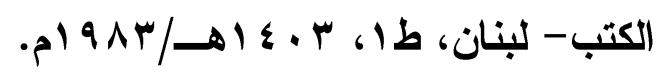

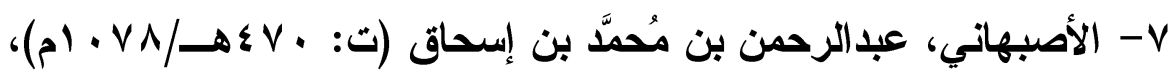

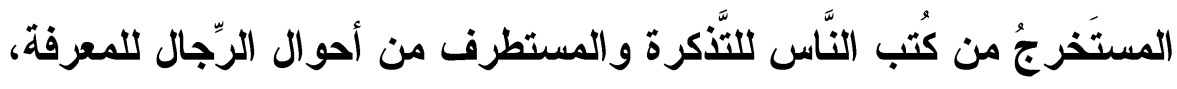

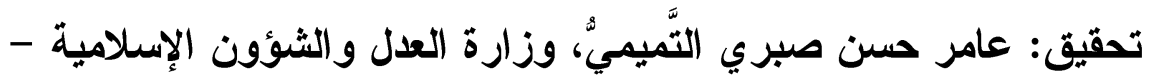

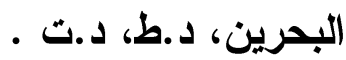

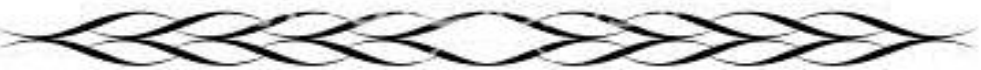




\section{الترقير الدولخ}

ISSN 2356-9050
Q 71 .

حولية كلية اللفة العربية بجرجا مجلة علمية محكمة

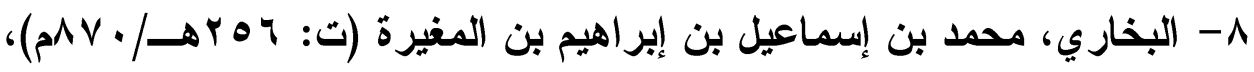

خلق أفعال العباد، تحقيق: عبد الرحمن عميرة، دار المعارف السعودية -

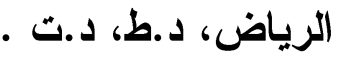

9- البركتي، مُحمَّ عميم الإحسان المجددي، التعريفات الفقهية، دار الكتب دهب دهات

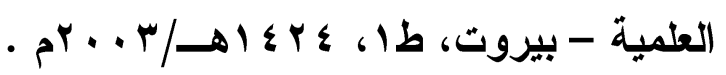

• 1 - البكري، أبو عبيد عبدالله بن عبدالعزيز بن مُحمَّ (ت:

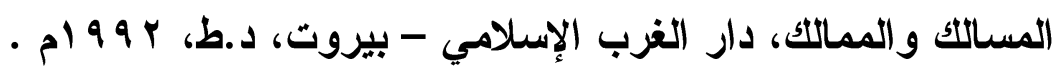

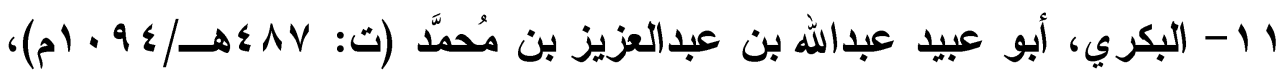

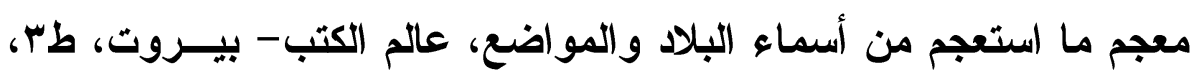

$$
\cdot \rightarrow 1 \varepsilon \cdot r
$$

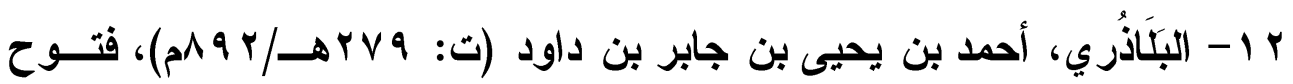

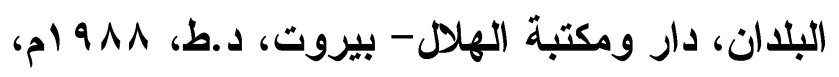

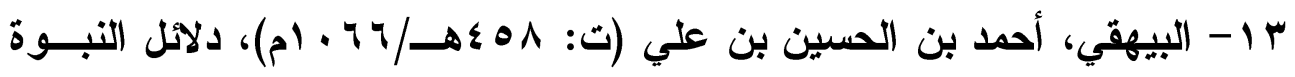

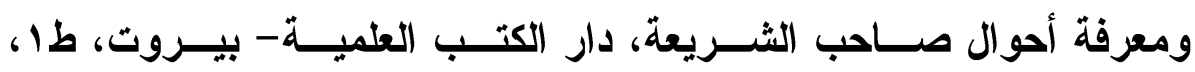

$$
\text { . } 1 \text {. } 0
$$

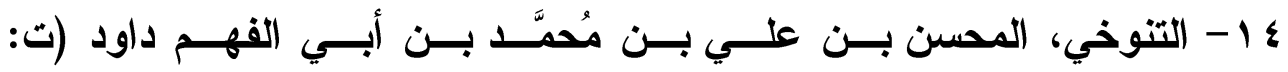

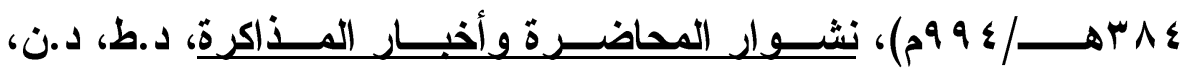

$$
\text { (1rqI }
$$

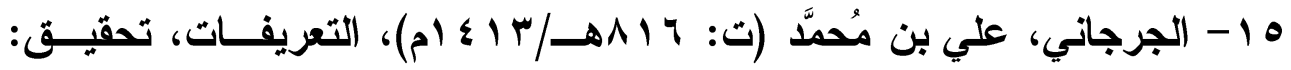

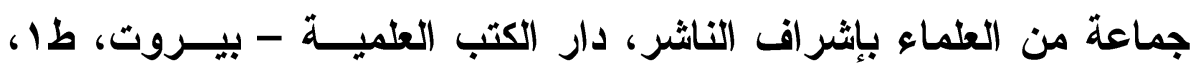

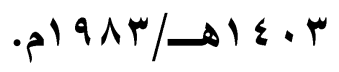

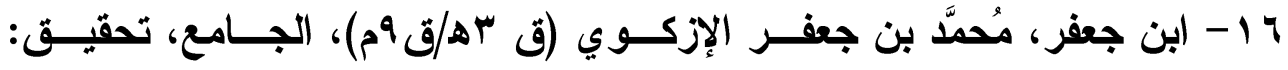

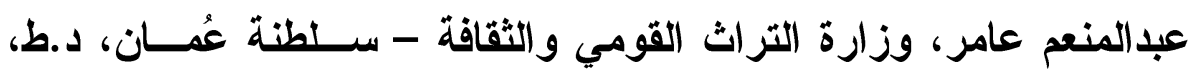

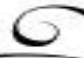




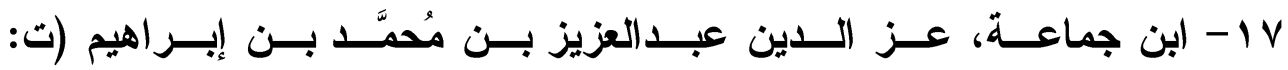

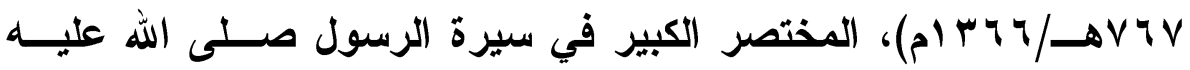

وسلم، تحقيق: سامي مكي العاني، دار البشير - عمان، طا، بـو9 ام. 9 ام.

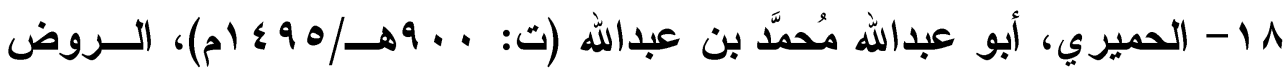
المعطار في خبر الأقطار، تحقيق: إحسان عباس، مؤسسة ناصر للثقافة -

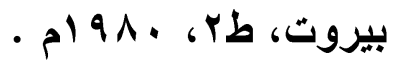

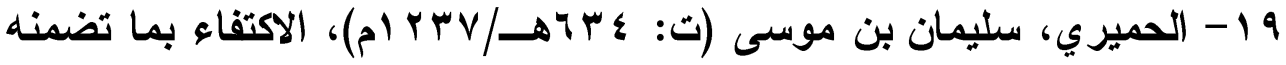
من مغازي رسول الله صلى الله عليه وسلم والثلاثة الخلفــاء، دار الكتــبـ

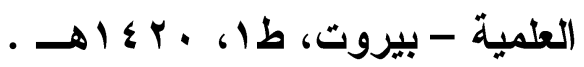

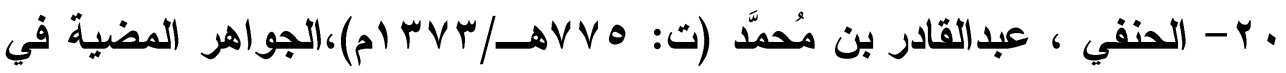

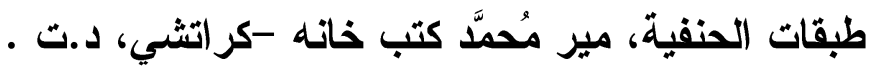

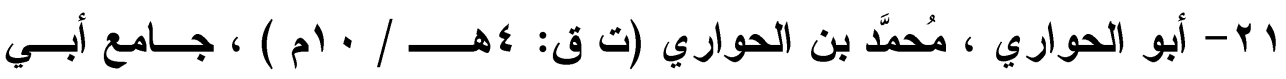

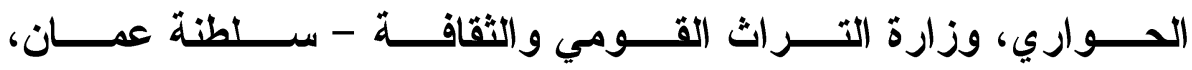

$$
\text { - مो90/- 18.0 }
$$

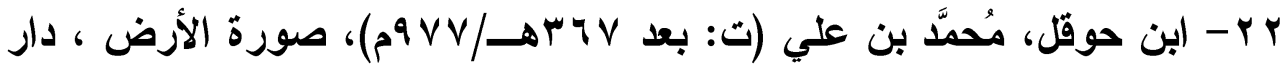

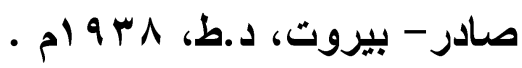

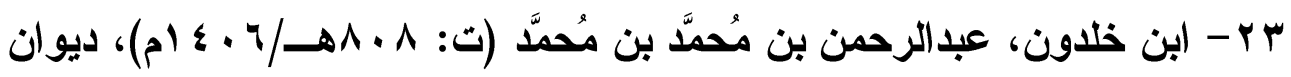
المبتدأ والخبر في تاريخ العرب والبربر ومن عاصرهم مسن ذوي الثــأن

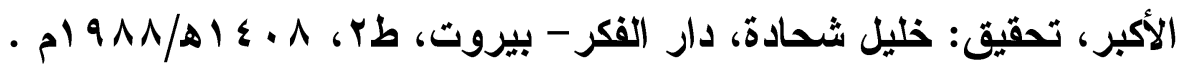

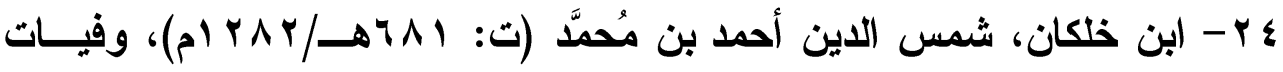

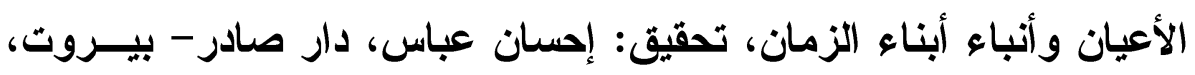

$$
\text { - pl9V1 b }
$$

ه - خليفات، مُحمَّ عوض، الأصول التاريخية للفرقة الإباضية، وزارة التــراث

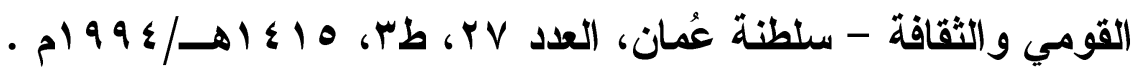

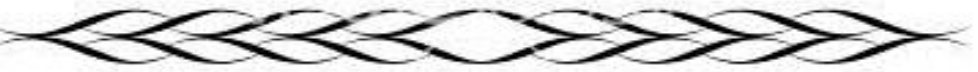




\section{الترقير الدولخ \\ ISSN 2356-9050}

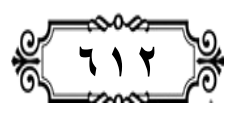

צr - نشأة الحركة الإباضية، وزارة التراث القومي والثقافة - ســلطنة عُمــان،

$$
\text { ط إ، س }
$$

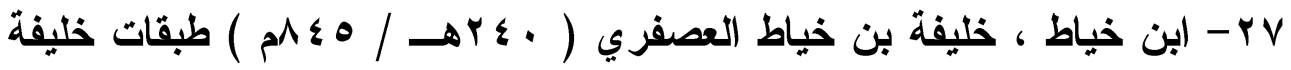
بن خياط، رواية : أبي عمران موسى بن زكريا بن يحيى التستري (ت ق

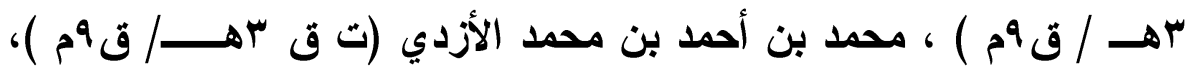

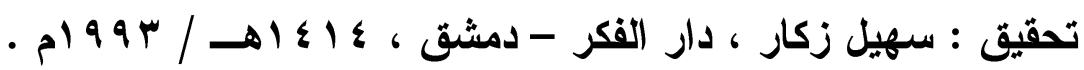

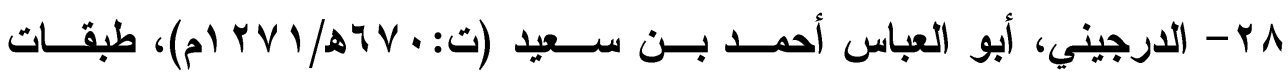

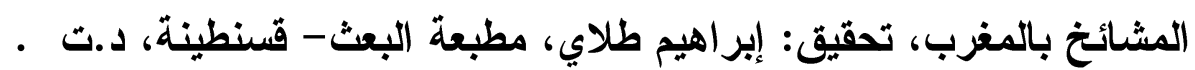

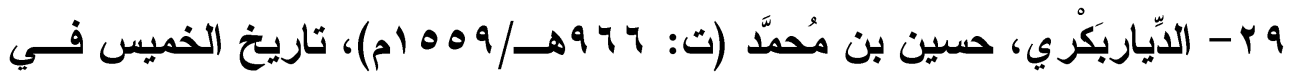

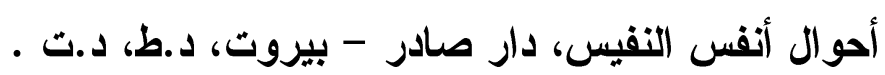

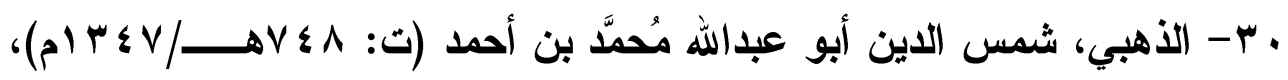
تاريخ الإسلام ووفيات المشاهير والأعلام، تحقيق:عمر عبدالسلام التدمري،

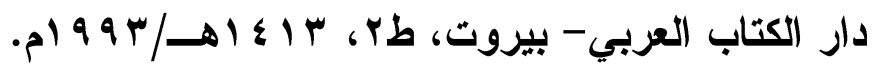

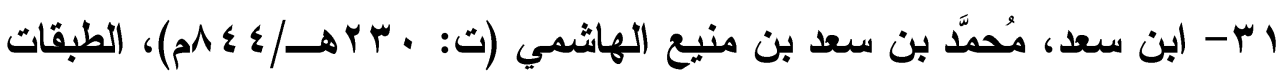

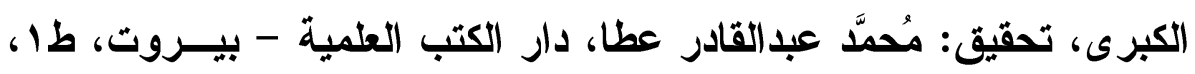
. $\rightarrow \leqslant 1$.

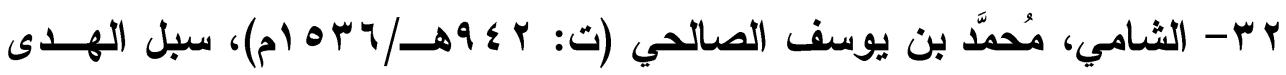
والرشاد في سبرة خير العباد، وذكر فضائله وأعلام نبوته وأفعاله وأحواله

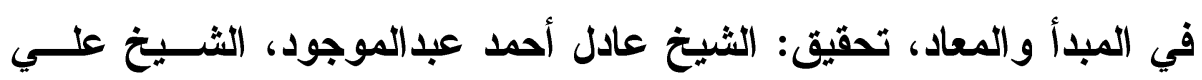

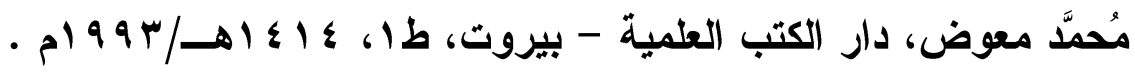
rr- الشقصي، خميس بن سعيد بن علي (القرن الهـ/ ا ام)،منهج الطـالبين

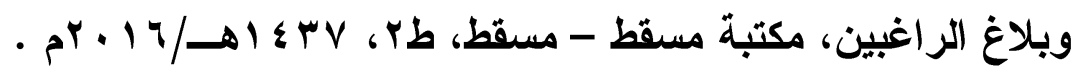

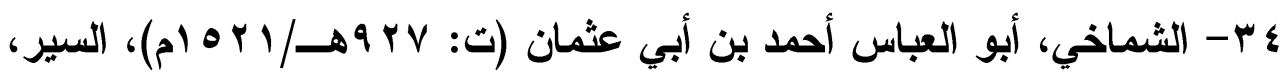

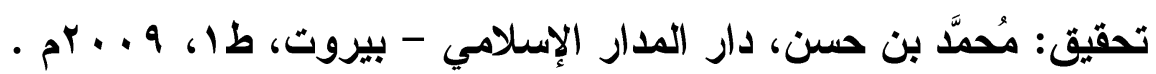

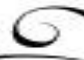




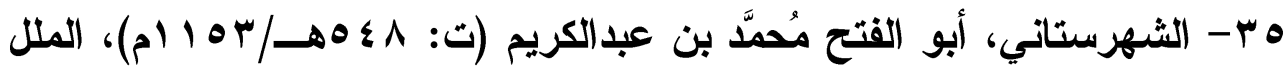

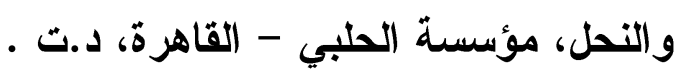

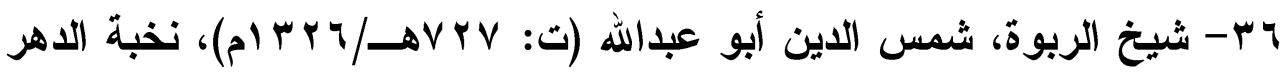
في عجائب البر والبحر، دار إحياء التــراث الإســلامي - بيـروت، طب،

$$
\text { - } 1991
$$

VV - الصوافي، صالح بن أحمد، الإمام جابر بن زيد العماني وآثاره في الدعوة،

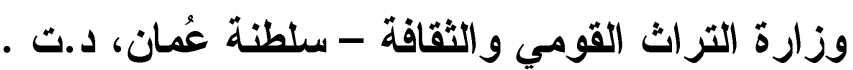

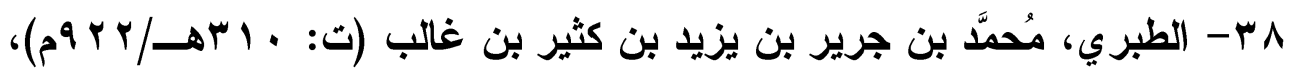

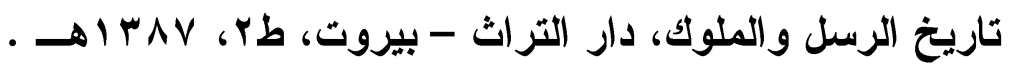

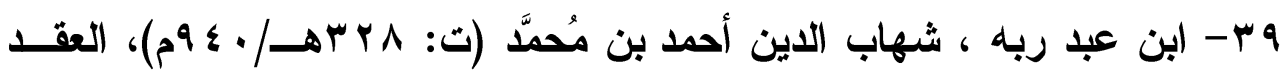

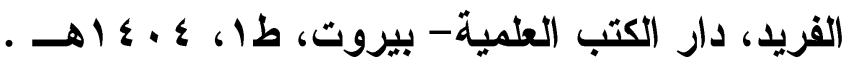

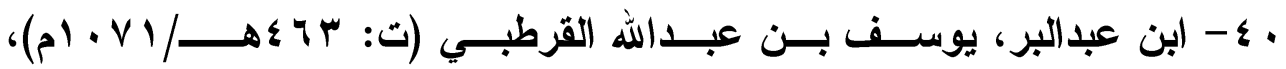
الاستيعاب في معرفة الأصحاب، تحقيق: علي مُحمَّد البجـــاوي، دار الجيـلـل

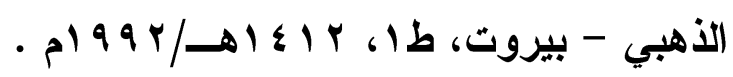

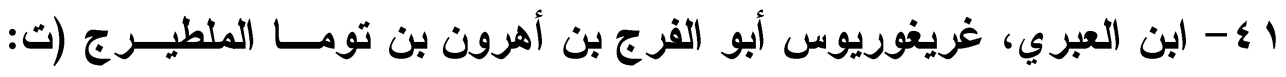

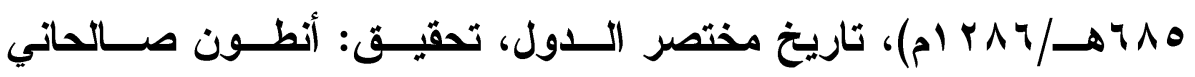

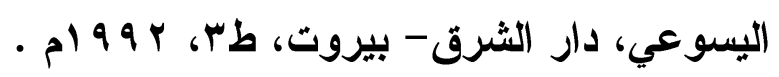

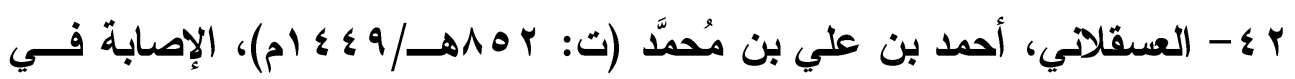

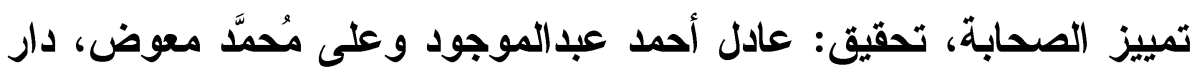

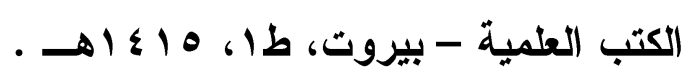

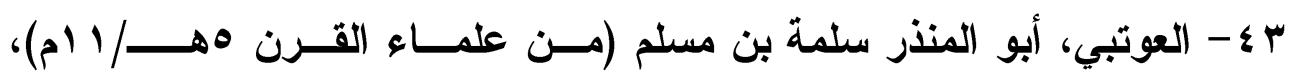

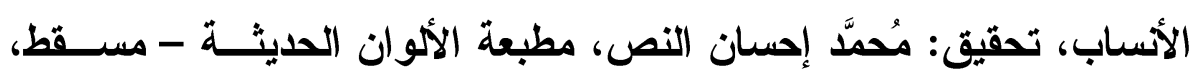

$$
\text { ط }
$$




\section{الترقير الدولخ}

ISSN 2356-9050

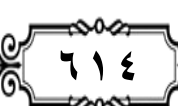

حولية كلية اللفة العربية بجرجا مجلة علمية محكمة

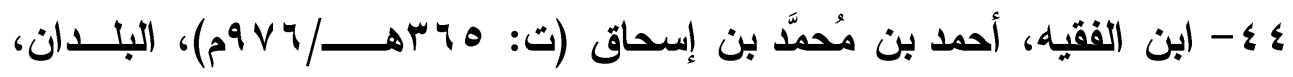

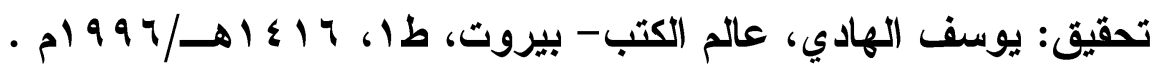

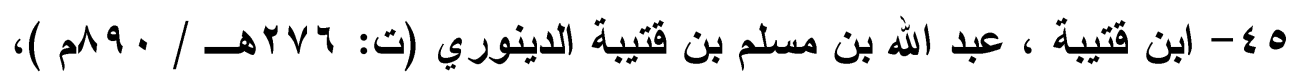
المعارف ، تحقيق : ثروت عكاثة، الهيئة المصرية العامة للكتاب - القاهرة

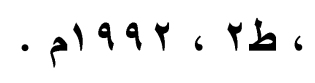

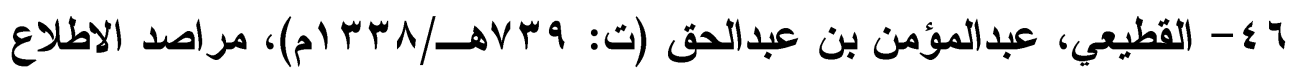

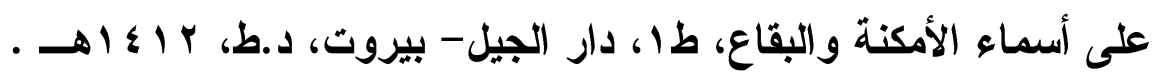

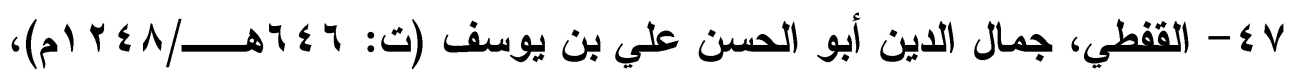

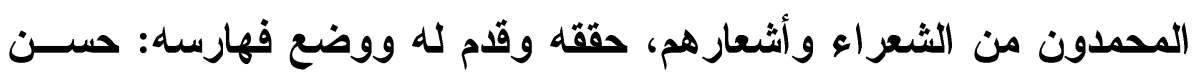

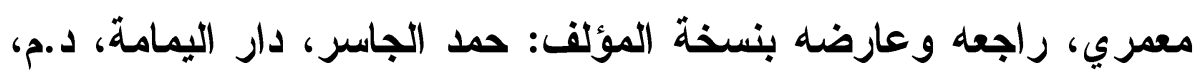

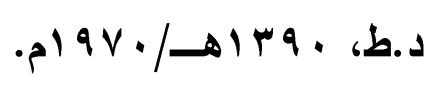

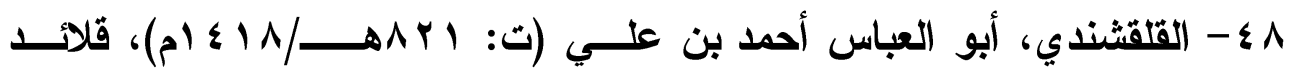
الجمان في التعريف بقبائل عرب الزمان، تحقيق: إبــراهيم الإبيـاري، دار

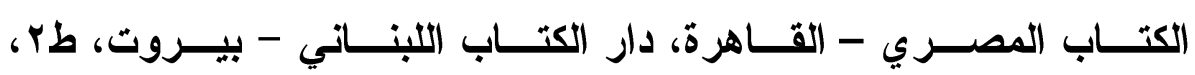

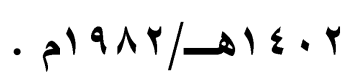

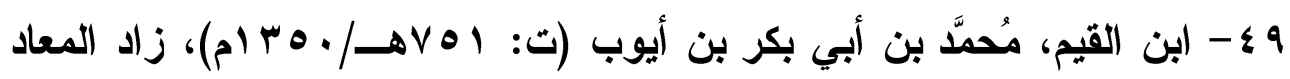

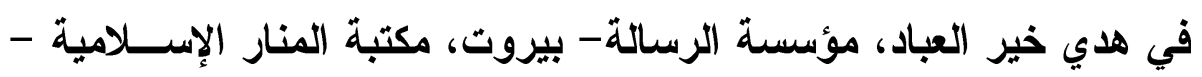

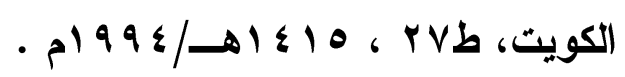

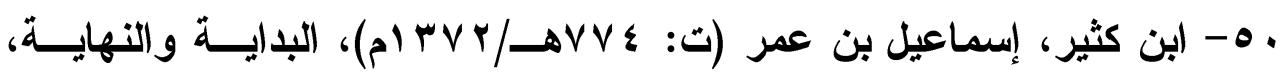

تحقيق: علي شيري، دار إحياء التراث العربي- بيزوت، طا، 1 ، ـ أهـ.

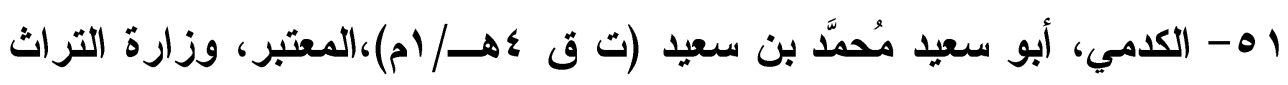

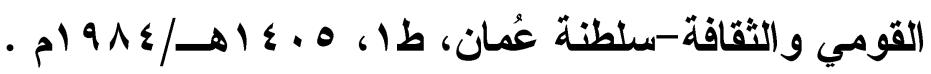




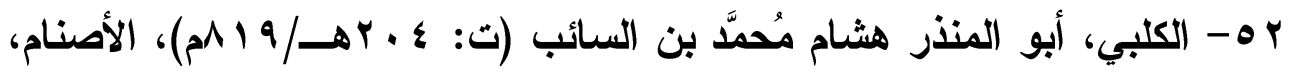

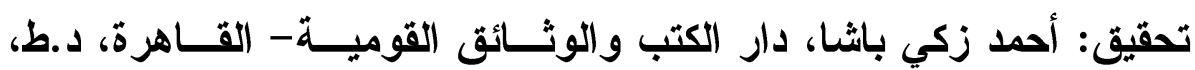

$$
\text { - } r \text { r } 1 \leqslant / 01 \leqslant r 0
$$

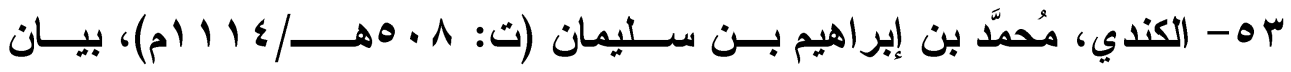

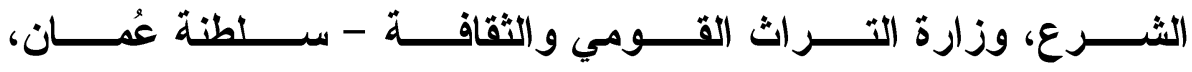

$$
109 \text { ، 10 ج ج }
$$

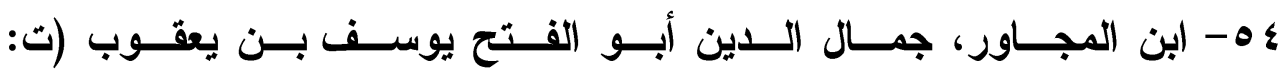

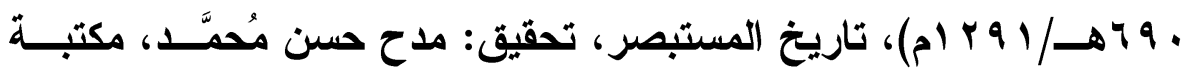

$$
\text { الثقافة الدينية - القاهرة، د.ط، جو } 99 \text { ام. }
$$

هـ - مجهول ، السير والجوابات لعلماء وأئمة عُمان، تحقيق: سـيدة إســماعيل

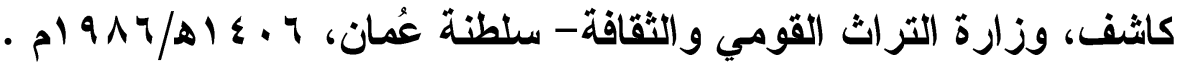
צه - مجهول، تاريخ أهل عُمان، تحقيق: سعيد عبدالفتاح عاثور، وزارة التراث

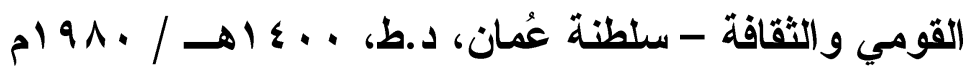

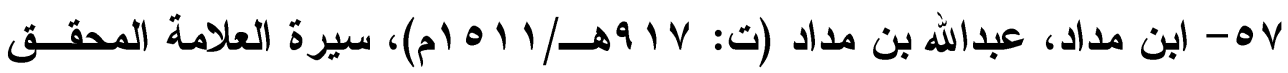
ابن مداد، وزارة التراث القومي والثقافة - سلطنة عُمــان، د.ط، ع ؟ 9 ام، العدد ابن هـ، من سلسلة تر اثنا .

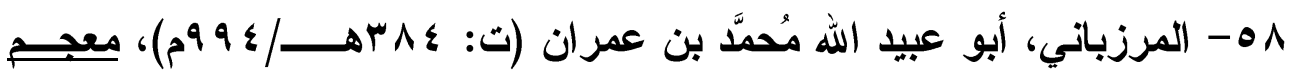
الشعراع، تحقيق: ف. كرنكو، مكتبة القدي، دار الكتب العلمية - بيروت،

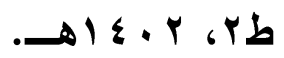

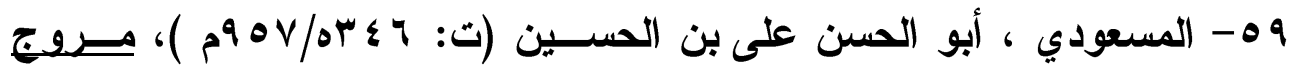

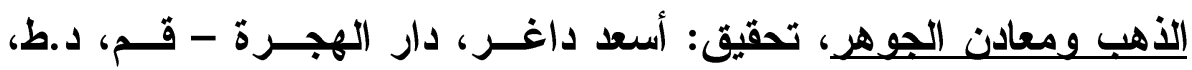




\section{الترقيم الدوله}

ISSN 2356-9050

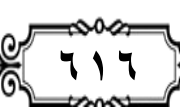

حولية كلية اللفة العربية بجرجا مجلة علمية محكمة

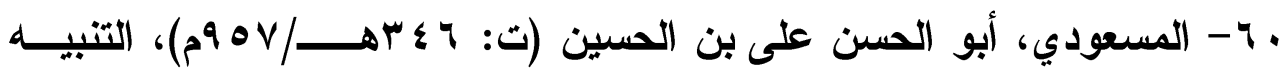
والإشراف، تصحيح: عبدالله إسماعيل الصاوي، دار الصــاوي- القــاهرة،

د.ت

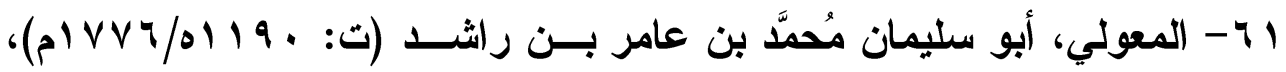
قصص وأخبار جرت في عمان، تحقيق: سعيد بن مُحمَّد الهاثــمي، وزارة

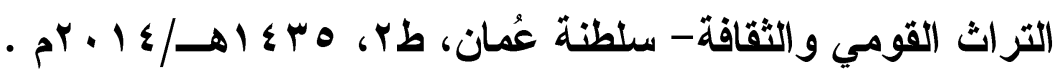

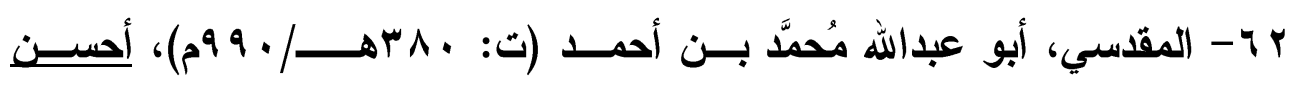

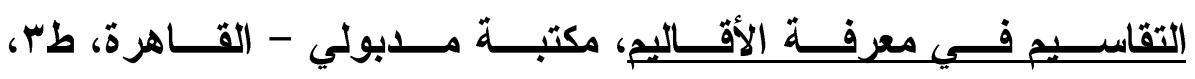
. $991 /-1 \leq 11$

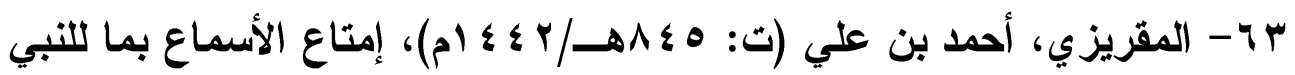

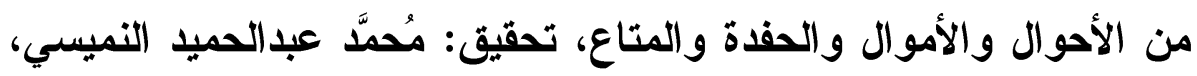

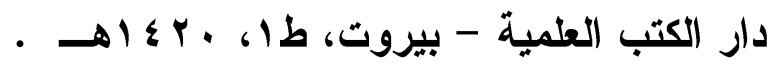

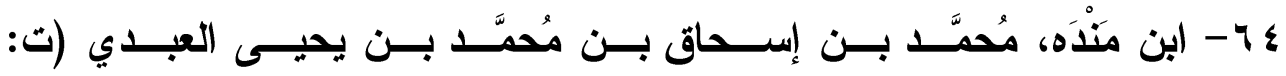

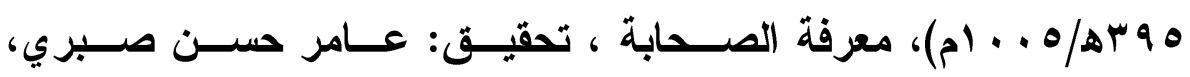

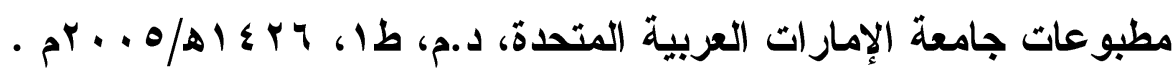

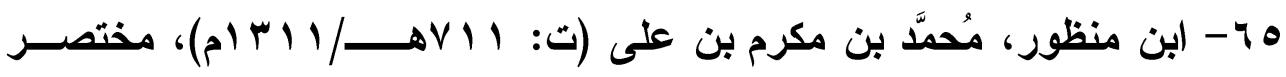

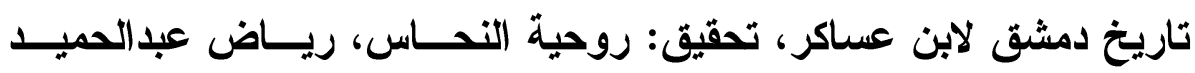

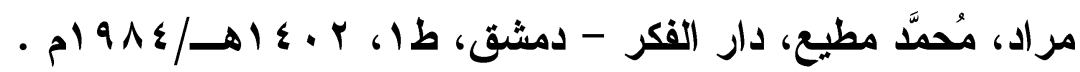

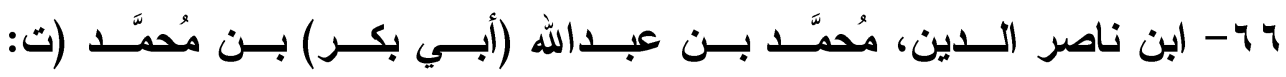

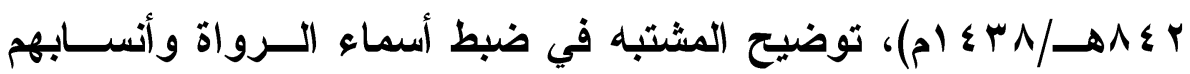

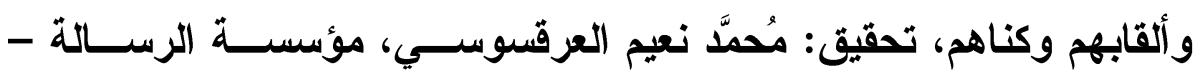

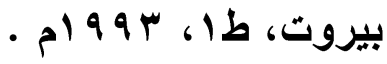




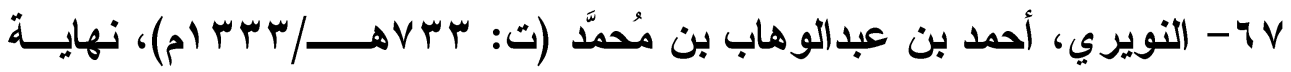

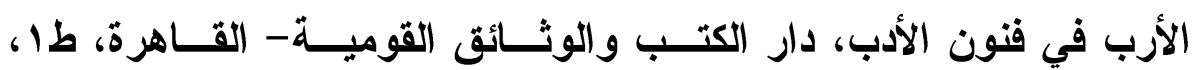

\section{. $1 \leqslant Y r$}

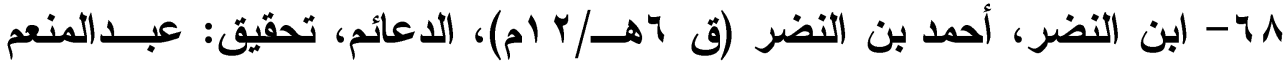

عامر، وزارة التراث القومي والثقافة - سلطنة عُمان، د.ط، د.ت .

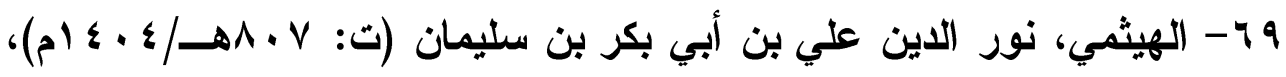
كثف الأستار عن زوائد البزار، تحقيق: حبيب الرحمن الأعظمي، مؤسسة

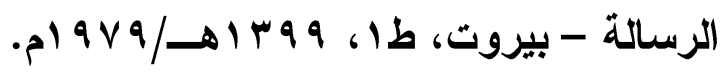

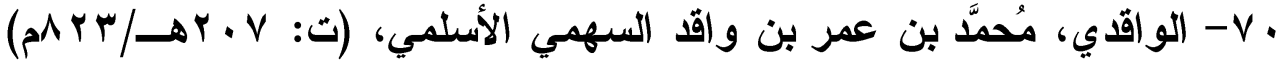
الردة مع نبذة من فتوح العراق وذكر المثنى بن حارثة الثيبانى، تحقيـق:

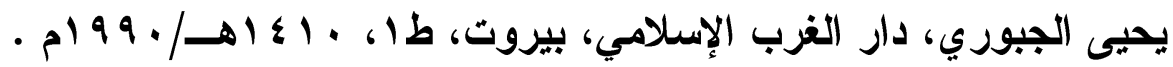

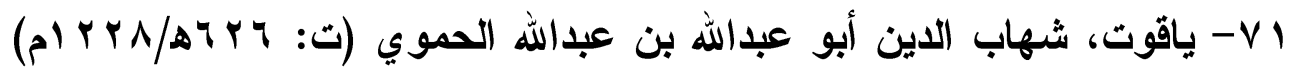

$$
\text { معجم البلدان، دار صادر - بيروت، طץ، ه9 } 99 \text { ام. }
$$

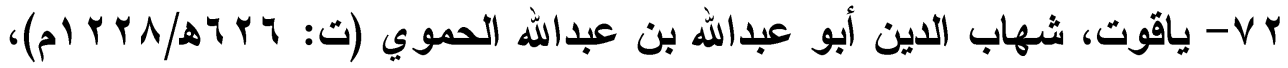
معجم الأدباء، تحقيق: إحسان عباس، دار الغزب الإسلامي - بيروث، طا،

1- البطاثـي، سيف بن حمود، إتحاف الأعيــان فـي تــاريخ بعـض علمــاء عُمان،مكتب المستشار الخاص لجلاله السلطان قابوس للشــؤون الاينيــة

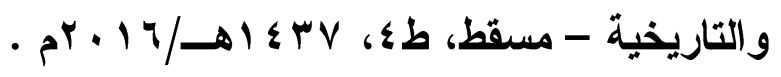

r- البكاي، لطيفة، حركة الخوارج نشأتها وتطورها إلى نهاية العهـــ الأمــوي

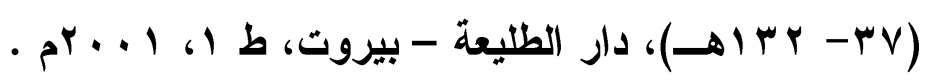

r- الجعبيري، فرحات، البعد الحضاري للعقيدة الإباضية، مكتبة الاسـتقامة -

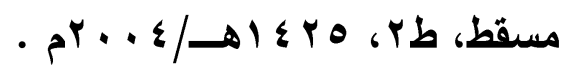




\section{الترقير الدولخ}

ISSN 2356-9050
O.
حولية كلية اللفة العربية بجرجا مجية مجلة علمية محكمة

ع - الجهضمي ، زايد بن سليمان ، حياة عُمان الفكرية حتى نهاية القرن الأول

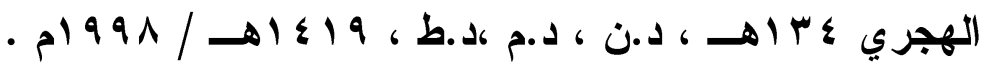

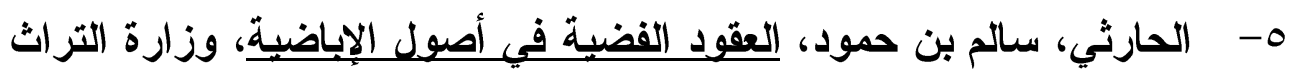

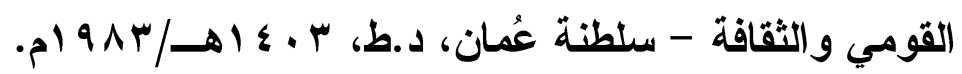

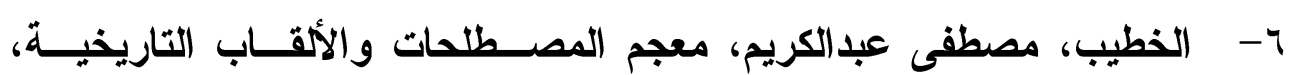

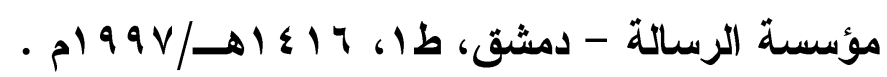
-V

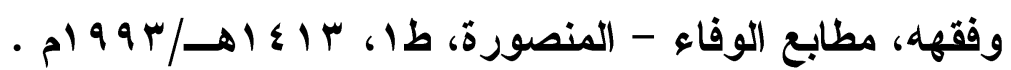

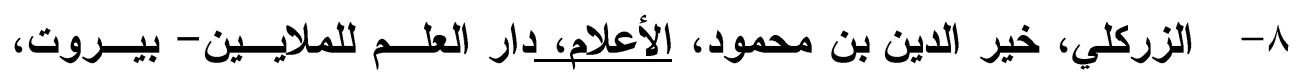

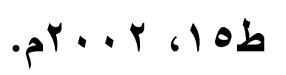
9- أبو زهرة، مُحمَّد، تثاريخ المذاهب السياسية والعقائــــ وتــاريخ المــذاهب

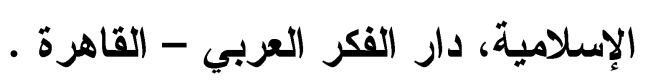

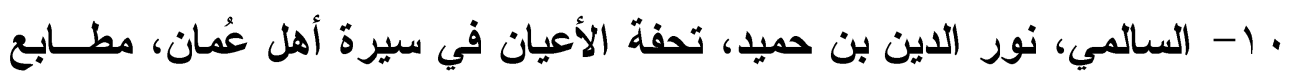

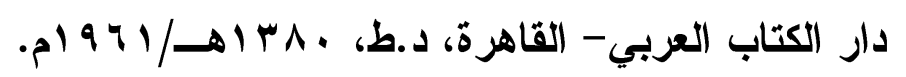

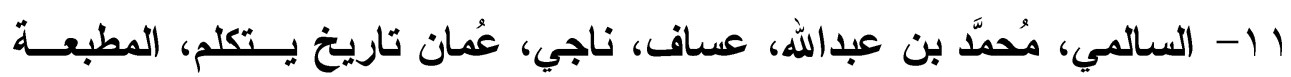

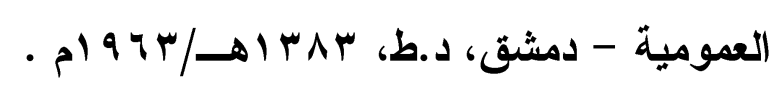

r ا - السعدي، فهل بن علي بن هاثل، معجم الفقهاء والمتكلمين (قسم المشرق)

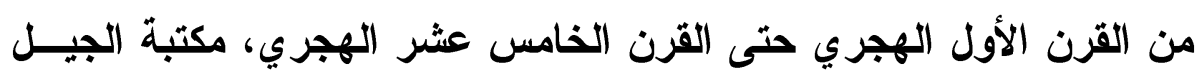

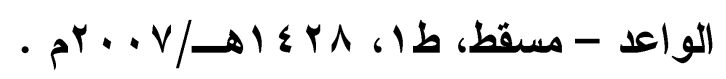

برا- السني، عبداله بن مسعود، الإباضية في ميزان أهل السنة، د.ن، د.م، د.ط، د.ت

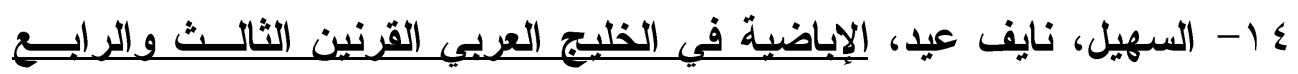

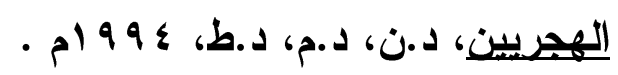


10 - الثلبي، حد بن سالم، الصحابة العُمانيون، مكتبة وتسجيلات البلر - ولاية

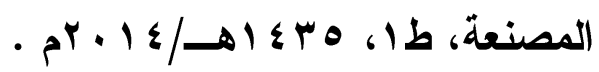

דا - العاني، عبدالرحمن عبدالكريم، تاريخ عُمان في العصور الإســلامية ودور

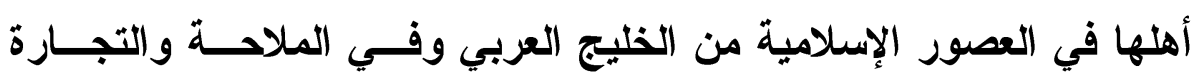

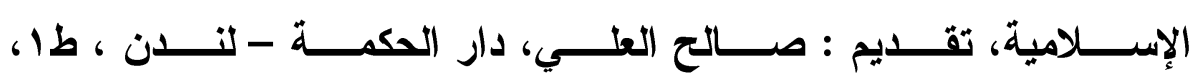
- $1999 / \Delta 1 \leqslant r$.

IV

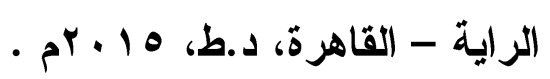

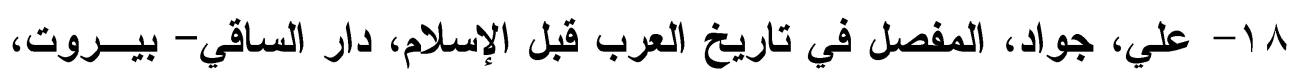

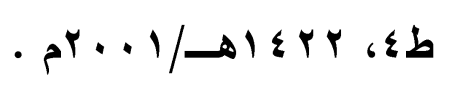

9 1 - الفارسي، ناصر بن منصور بن ناصر، نزوى عبر الأيام "معــالم وأعــلام"،

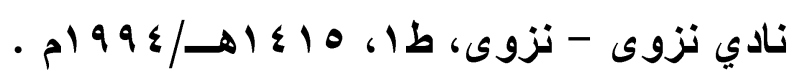

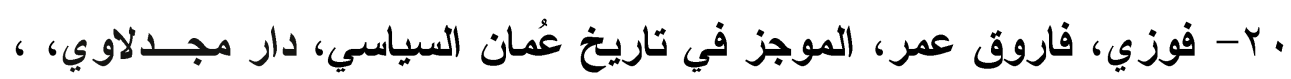

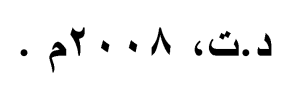

ا Y- القحطاني، سعيد بن على بن وهف، عقيدة المسلم في ضوء الكتاب والسئّةّة

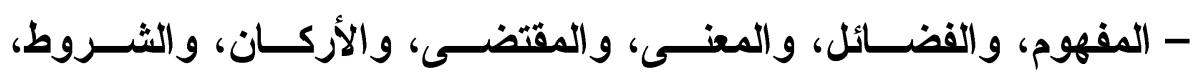
و النو (قص، و النو اقض، مطبعة سفير - الرياض، د.ط، د.ت . .

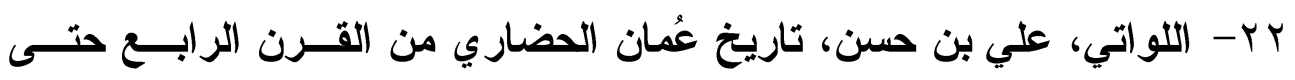
القرن السادس للهجرة دراسة في الحياة الاجتماعية والاقتصادية و الفكرية،

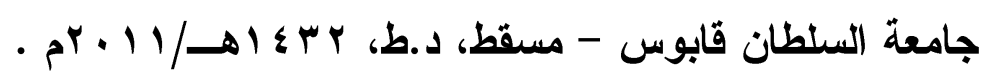
بץ- مجموعة مؤلقين ، موسوعة السلطان قابوس لأعلام العرب دليـلـل أعـلام

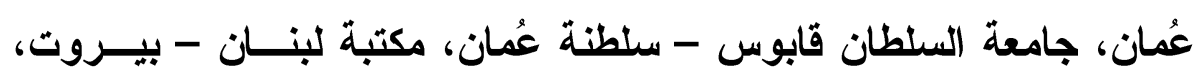

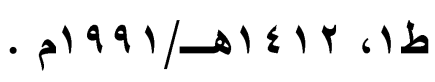




\section{الترقير الدول\$ \\ ISSN 2356-9050}

Q. 9 (T)

حولية كلية اللفة العربية بجرجا مجية مجلة علمية محكمة

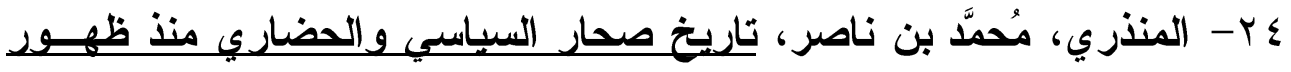

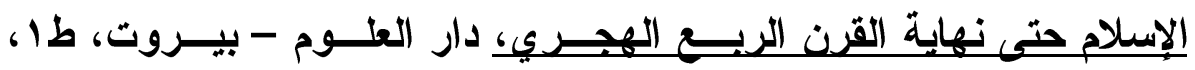

$$
\cdot r+1 / \infty 1 \leqslant r q
$$

0 - ناصر، مُحمَّد صالح، الثيباني، سلطان بن مبارك، معجم أعلام الإباضية من

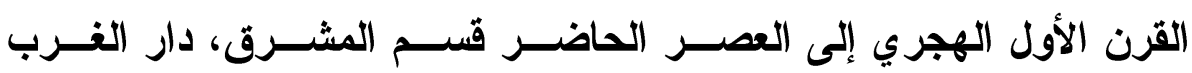

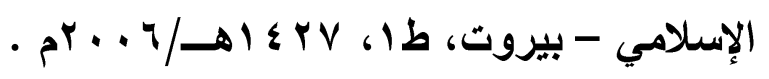

ب - الهاثمي، سعيد بن مُحمَّد، دراسات في التاربخ العُماتي الإسلامي والحديث،

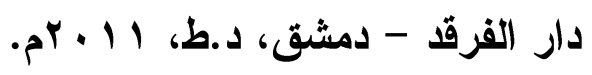

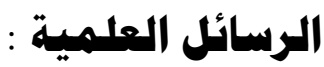

1- الدوسري، شيخة بنت مُحمَّ بن فــــــــالح، النفوذ البويهي والسلجوقي

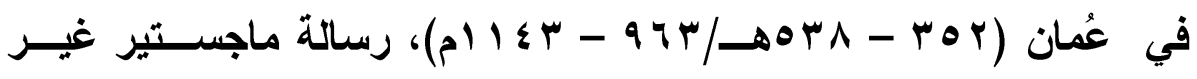

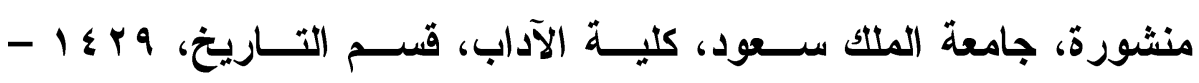

$$
\text { • } r \cdot q-r \cdot 1 / \Delta-1 \leqslant r .
$$

r- الزاملي، أحمد بن علي، منهج الثيخ عبدالرزاق عفيفي وجهوده في تقرير

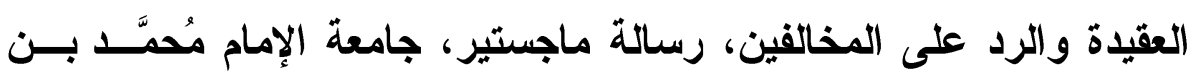

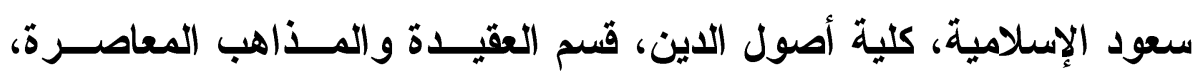

$$
\text { - } \rightarrow \leqslant \mu \mid
$$

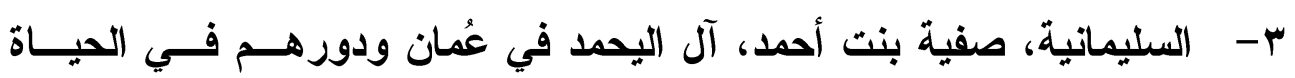

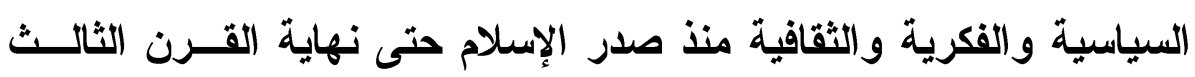

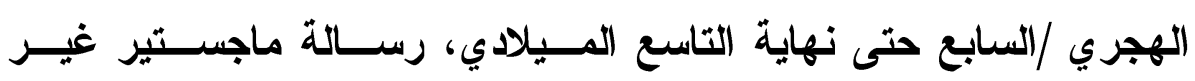

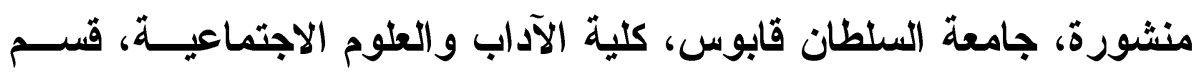

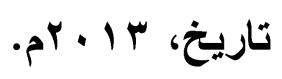


ع - سيد أحمد، محمود أحمد مُحمَّ، الحياة السياسية وأهم مظاهر الحضارة في

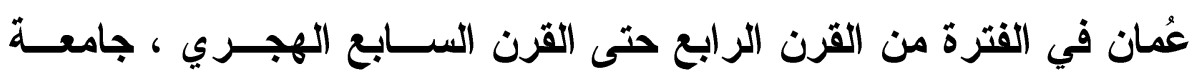

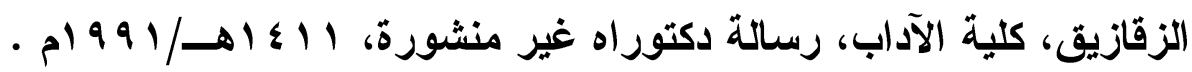
الندوات : الجنحاني، حبيب، دور عُمان في نشاط التجارة العالمية، حصاد نــدوة

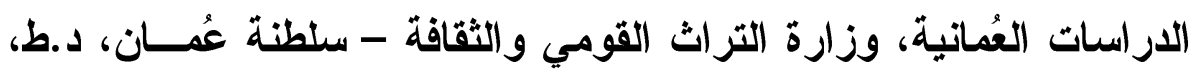

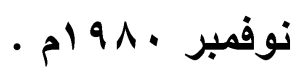

\section{المراجع الأجنبية المهربة:}

- - ويلكسون، جون، صحار تاريخ وحضارة، وزارة التراث القومي والثقافة -

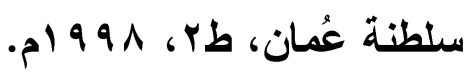

r- فيليس، وندل، تاريخ عُمان، ترجمة: مُحمَّد أمين عبـــالله، وزارة التــراث

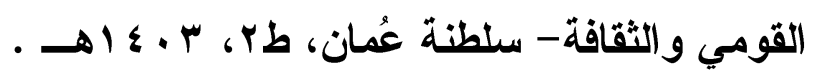




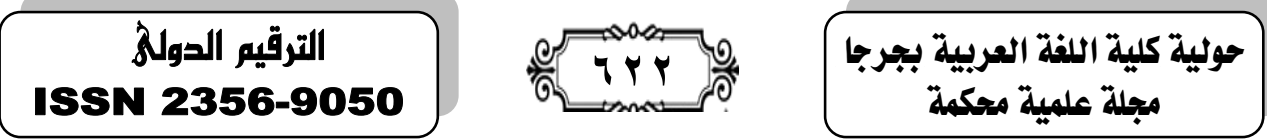

فهرس الإوضوعات

\begin{tabular}{|c|c|c|}
\hline |لصفية & الأوضـا & $\hat{P}$ \\
\hline $07 V$ & هذص الدراسة & 1 \\
\hline $0 \curlyvee 1$ & Study Summary & r \\
\hline 099 & المقدمِّة & r \\
\hline ov. & جغرافية عمُان & $\varepsilon$ \\
\hline$\bullet V$. & هوقع عمان & 0 \\
\hline OVI & السطح والمناخ & ฯ \\
\hline ovr & أصل تسمية عمُان بهذا الاسمي: & $v$ \\
\hline$\Delta \vee \varepsilon$ & الحياة الدينية في عمان قبل انتشار الإسلام & $\Lambda$ \\
\hline OV $\varepsilon$ & ا & 9 \\
\hline OV० & ب- المجوسية: & 1. \\
\hline OVT & ب- اليهوددية: & 11 \\
\hline OVA & 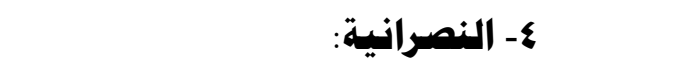 & ir \\
\hline OVA & اللذاهب والفرق الإسلامية & Ir \\
\hline $7 \cdot V$ & 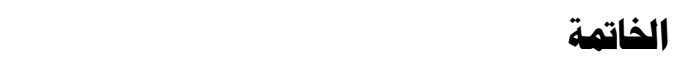 & $1 \varepsilon$ \\
\hline 7.9 & المادر والمراجع & 10 \\
\hline Trr & فهرس الموضوعات & 17 \\
\hline
\end{tabular}

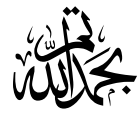

